\title{
30. LATE CRETACEOUS AND CENOZOIC EVOLUTION OF THE NEW JERSEY CONTINENTAL SLOPE AND UPPER RISE: AN INTEGRATION OF BOREHOLE DATA WITH SEISMIC REFLECTION PROFILES ${ }^{1}$
}

\author{
C. Wylie Poag, U.S. Geological Survey, Woods Hole \\ and \\ Gregory S. Mountain, Lamont-Doherty Geological Observatory²
}

\begin{abstract}
Fifteen intersecting single-channel seismic reflection profiles and fifteen multichannel profiles are integrated with coring and downhole logging data from DSDP Sites 604, 605, 612, and 613 to interpret the stratigraphic framework and depositional history of the Campanian to Pleistocene deposits of the New Jersey Transect (Continental slope and rise). Twelve seismic and depositional sequences, each bounded by erosional unconformities, are recognized within the upper rise prism and 13 are recognized on the slope. All the slope sequences have been documented by drilling, but four on the rise have not been drilled, and their precise ages are unknown. Isopach maps delineate the distribution patterns and depositional-erosional fabric of each sequence. The study area has been the locus of repeated episodes of massive downslope sediment transport that have created extensive systems of erosional channels and have produced a downslope "ribbed" geometry for each sequence mapped. Our results show that most depositional and erosional features in the study area are equivalent to deposits and stratigraphic gaps previously documented on the adjacent shelf and coastal plain. Our interpretation of the sedimentary history is compatible with the Vail model of global sea-level change.
\end{abstract}

\section{INTRODUCTION}

Four nearly continuously cored boreholes on the New Jersey Continental Slope and Upper Rise, drilled by the Deep Sea Drilling Project (Sites 604, 605, 612, and 613; Legs 93 and 95) permit us to interpret the detailed stratigraphy of a grid of intersecting high-resolution singlechannel and multichannel seismic reflection profiles. Heretofore, a few intermittently cored boreholes had been drilled on the continental slope (Poag, 1985a), but no boreholes had penetrated the upper rise.

On the basis of sparse previous data and a few surficial cores and grab samples, several authors have analyzed the seismostratigraphy and morphology of Neogene and Quaternary strata of the New Jersey Slope (Robb et al., 1981; Prior et al., 1984; Poag, 1978, 1979, 1984, 1985a; Hampson and Robb, 1984). Without benefit of boreholes on the upper rise, Tucholke and Mountain (1979), and Klitgord and Grow (1980), attempted to interpret the general stratigraphic section there by long range correlations from distant deep-sea boreholes (e.g., DSDP Sites 105, 106, 388; Fig. 1).

Four studies have been carried out since the drilling by Legs 93 and 95 (van Hinte, J., Wise, S. W., Jr., et al., in press). Robb and Hampson (1983) surveyed the surficial geology of the upper rise. Poag (1985b) and Mountain and Tucholke (1985) presented divergent interpretations of the deeper upper-rise stratigraphy, although they and Farre (1985) agree rather closely on the the historical development of the continental slope.

\footnotetext{
${ }^{1}$ Poag, C. W., Watts, A. B., et al., Init. Repts., DSDP, 95; Washington (U.S. Govt. Printing Office).

2 Addresses: (Poag) U.S. Geological Survey, Woods Hole, MA, 02543; (Mountain) Lamont-Doherty Geological Observatory, Palisades, NY, 10964.
}

This chapter presents refined interpretations of the multichannel seismic reflection lines (Fig. 1) and incorporates an additional series of high-resolution singlechannel seismic reflection profiles (Fig. 2), which includes crossings of (or near) the principal boreholes of the slope and rise.

The stratigraphic framework and facies relationships presented by Poag (1985b) apply to this study, although with some important modifications. Poag recognized 12 depositional sequences on the upper rise. We have reassessed those sequences, combining Poag's Sequence 5 (?lower Miocene?) with Sequence 4 (?middle Miocene), and dividing Sequence 12 (Maestrichtian/Campanian) into two separate sequences. Renumbering from top to bottom still yields 12 sequences (Fig. 3), but below Sequence 4, the numbers are one digit smaller than Poag's (e.g., Poag's 8 is our 7). We also have treated the four undrilled sequences $(4,5,6,7)$ more conservatively, generally referring to them by number rather than by their presumed (but undocumented) chronostratigraphic positions.

The Pleistocene sequence of the upper rise prism is subdivided into Unit A (upper) and Unit B (lower). Unit A can be further subdivided into subunits $A_{1}$ (upper) and $\mathrm{A}_{2}$ (lower).

\section{DATA BASE AND ANALYTICAL METHODS}

Many multichannel and single-channel seismic profiles have been obtained over various parts of the study area by various institutions. Two relatively closely spaced, overlapping grids of intersecting lines constitute the chief components of this analysis. The first seismic grid contains 15 intersecting multichannel lines covering a 48- $\times$ $140-\mathrm{km}$ area at ca. 15- to $20-\mathrm{km}$ spacings (Fig. 1). Ten of 


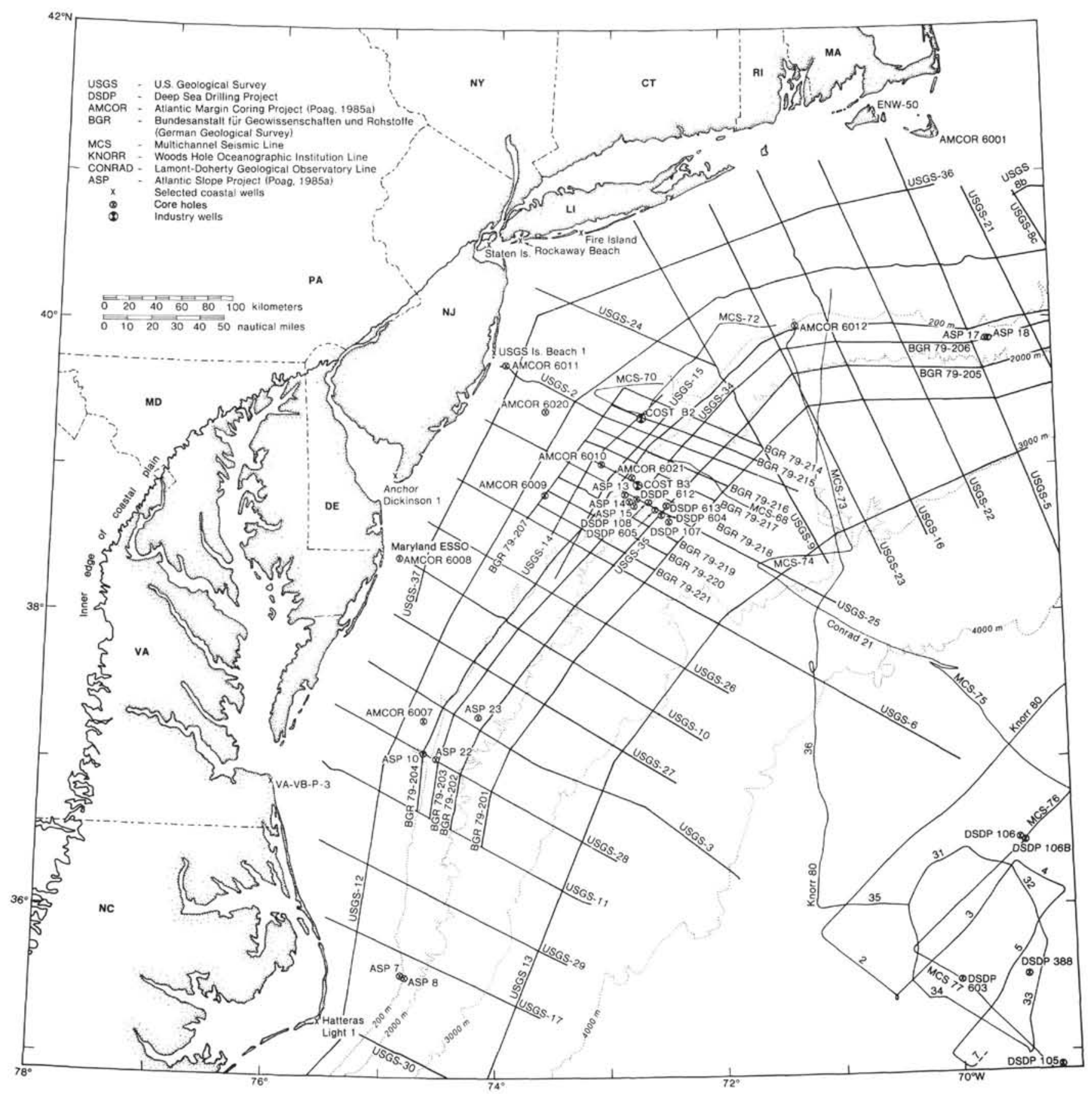

Figure 1. Location of boreholes and grid of multichannel seismic profiles in the vicinity of the New Jersey Transect.

these lines are unpublished, part of a joint U.S.G.S.BGR (Bundesanstalt für Geowissenschaften und Rohstoffe) program carried out in 1979 by Prakla Seismos (see Schlee and Fritsch, 1981, for collection and processing information). Three of the lines $(25,34$, and 35$)$ are published U.S.G.S. lines that have been used as standard references for this area (Poag, 1985a, b). The remaining two lines, 2 and 6 , are also published U.S.G.S. lines (see Schlee, 1981). A second grid consists of singlechannel profiles obtained by the U.S.G.S. in 1978-1979 (Fig. 2). It covers a $40-\times 35-\mathrm{km}$ area with approximately 900- to $1,700-\mathrm{m}$ line spacing (Robb et al., 1981). We se- lected 15 of these single-channel lines ( 9 strike lines; 6 dip lines) for detailed analysis, including those that cross or nearly cross the principal boreholes.

The borehole control for this study is chiefly that derived from DSDP Sites 604, 605, 612, and 613 (Figs. 1, 2; Poag, 1985b; Poag and Low, this volume). These are supplemented by intermittently cored sites (ASP 14, 15; AMCOR 6021; Poag, 1985a), and by rotary cuttings from the COST B-3 well (Figs. 1, 2; Poag, 1980, 1985a).

Thickness of strata on seismic lines (where not drilled) was estimated using sonic velocity values from downhole geophysical logs obtained at Sites 612 and 613 (see 


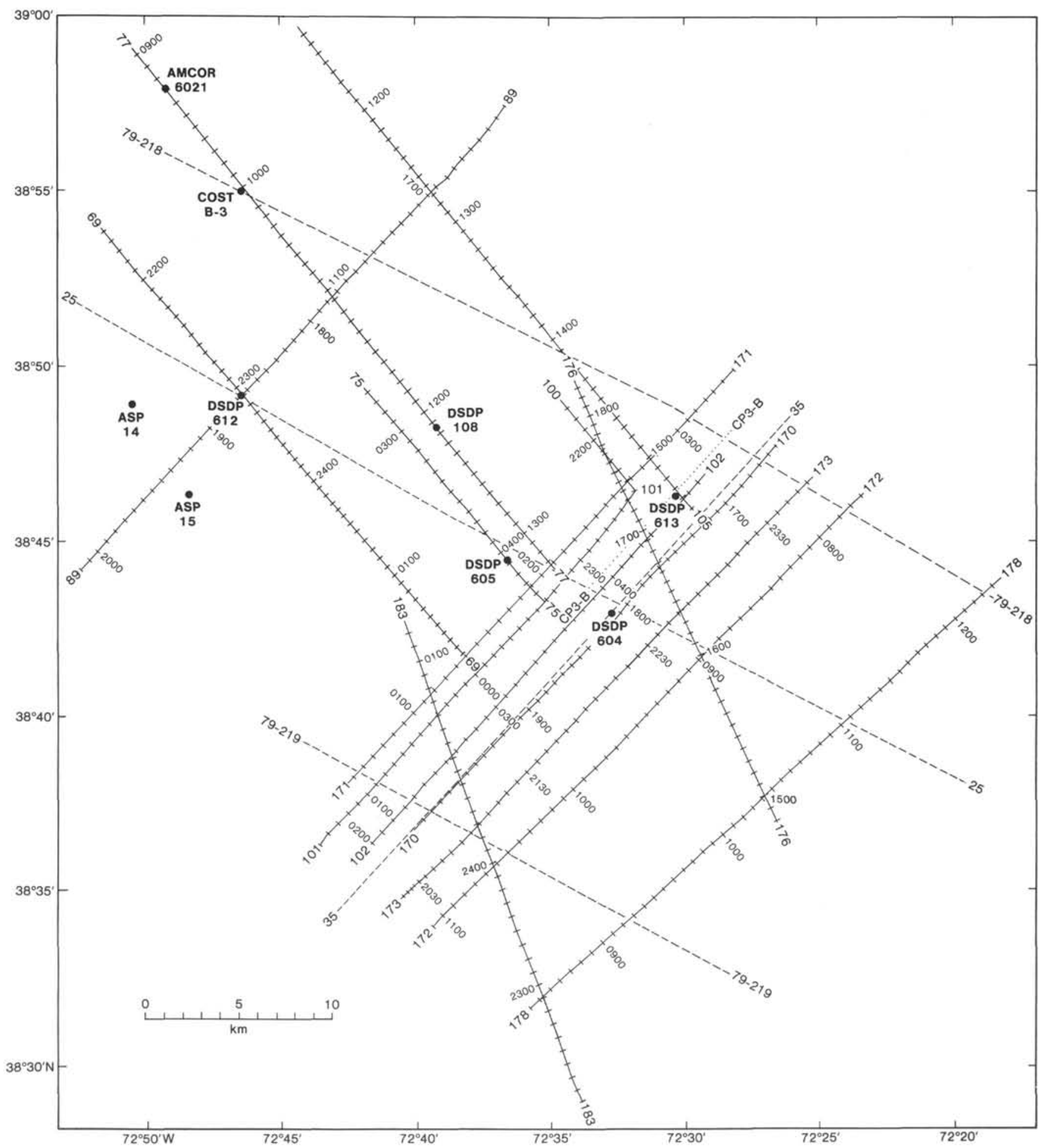

Figure 2. Location of boreholes and selected grid of single-channel seismic profiles (solid lines with ticks) in the vicinity of the New Jersey Transect. Four-digit numbers by ticks indicate hourly navigation marks and correspond to hour marks on the interpreted profiles. Key multichannel lines shown by dashed lines. Multichannel Line 34 (not shown) is nearly coincident with Line 89. Dotted Line CP3-B is a single-channel line recorded on Glomar Challenger during Leg 95 (see Site 612 chapter, this volume). ASP = Atlantic Slope Project; AMCOR = Atlantic Margin Coring Project; COST $=$ Continental Offshore Stratigraphic Test (Poag, 1985a). 


\begin{tabular}{|c|c|c|c|c|c|}
\hline \multicolumn{4}{|c|}{$\begin{array}{l}\text { Upper-rise } \\
\text { sequences }\end{array}$} & \multirow{2}{*}{$\begin{array}{c}\text { Upper-rise } \\
\text { equivalents } \\
\text { (Mountain \& Tucholke) }\end{array}$} & \multirow{2}{*}{ Characteristics of upper-rise sequences } \\
\hline No. & Symbol & Age & & & \\
\hline 1 & & \multicolumn{2}{|c|}{ Quaternary } & \multirow[t]{2}{*}{ Pleistocene } & $\begin{array}{l}\text { Widespread; chiefly terrigenous; displaced shelf faunas; reworked Eocene clasts, } \\
\text { slope-front, onlap- and chaotic-fill; sampled at DSDP } 604,605,612,613 ; \text { ASP } 14 \text {, } \\
15 \text {; AMCOR } 6021 \text {; COST B-3. }\end{array}$ \\
\hline 2 & & \multicolumn{2}{|c|}{ Pliocene } & & $\begin{array}{l}\text { Widespread; chiefly terrigenous; reworked Eocene microfossils; upper surface channeled: } \\
\text { fills upper Miocene channels; onlap- and chaotic-fill; sampled at DSDP } 604,605,612 \text {, } \\
613 \text {. }\end{array}$ \\
\hline 3 & & \multicolumn{2}{|c|}{$\begin{array}{c}\text { late } \\
\text { Miocene }\end{array}$} & \multirow{4}{*}{$\begin{array}{c}\text { late } \\
\text { Miocene? }\end{array}$} & $\begin{array}{l}\text { Widespread; chiefly terrigenous; reworked Eocene clasts, mildly channelled; fills } \\
\text { channels on several older surfaces; slope-front, onlap--, and chaotic-fill, sampled } \\
\text { at DSDP } 604,612,613 \text {. }\end{array}$ \\
\hline & & $\begin{array}{c}\text { Not } \\
\text { known }\end{array}$ & $\frac{\pi}{\infty}$ & & $\begin{array}{l}\text { Limited to NE study area; chiefly terrigenous ?; fills channels on several underlying } \\
\text { sequences; severely eroded; onlap- and chaotic-fill: includes submarine fan facies; not } \\
\text { sampled in upper rise DSDP sites, and possible updip equivalent (upper Miocene) not } \\
\text { sampled at DSDP 612; COST B-3; ASP 14-15. }\end{array}$ \\
\hline 5 & & $\begin{array}{c}\text { Not } \\
\text { known }\end{array}$ & ¿ू & & $\begin{array}{l}\text { Limited to SW study area; chiefly terrigenous ?; thin sequence; severely eroded; slope- } \\
\text { front fill, onlap-fill and submarine fan facies; not sampled in upper rise DSDP sites, } \\
\text { but possible updip equivalent (middle Miocene) sampled at COST B-3, ASP 14,15. }\end{array}$ \\
\hline \multirow[t]{2}{*}{6} & & $\begin{array}{c}\text { Not } \\
\text { known }\end{array}$ & 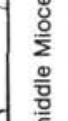 & & $\begin{array}{l}\text { Limited to SW study area; chiefly terrigenous ?; fills Eocene channels; severely eroded: } \\
\text { on lap-, mounded onlap-, chaotic-fill and submarine fan facies; not sampled in upper } \\
\text { rise DSDP sites, but possible updip equivalent (middle Miocene) sampled at COST B-3; } \\
\text { ASP_14.15. }\end{array}$ \\
\hline & & $\begin{array}{c}\text { Not } \\
\text { known }\end{array}$ & & Merlin- & $\begin{array}{l}\text { Limited to SW study area; patchy distribution; chiefly terrigenous ? severely eroded: } \\
\text { fills middle Eocene channels; onlap-and chaotic-fill; not sampled in upper rise DSDP sites, }\end{array}$ \\
\hline \multirow[b]{2}{*}{8} & & \multirow{2}{*}{\multicolumn{2}{|c|}{$\begin{array}{l}\text { middle } \\
\text { Eocene }\end{array}$}} & $\begin{array}{l}\text { middle and early } \\
\text { Miocene? }\end{array}$ & \multirow{2}{*}{$\begin{array}{l}\text { Continuous from slope to rise; chiefly biogenous; broad seafloor exposure; channeled, } \\
\text { very thick downdip; onlapped by several younger sequences; chiefly onlap-fill; subordinate } \\
\text { slope-front and chaotic-fill; sampled at DSDP } 605,612,613 \text {; COST B-3; ASP } 15 \text {. }\end{array}$} \\
\hline & & & & \multirow{2}{*}{$\begin{array}{l}\text { late } \\
\text { Oligocene? }\end{array}$} & \\
\hline \multirow[b]{2}{*}{10} & & \multicolumn{2}{|c|}{$\begin{array}{l}\text { early } \\
\text { Eocene }\end{array}$} & & $\begin{array}{l}\text { Continuous from slope to rise; chiefly biogenous: porcellanite and very deep channels } \\
\text { associated with upper surface; onlap-and chaotic-fill; slumps observed in cores; } \\
\text { sampled at DSDP } 605,612,613 \text {; COST B-3. }\end{array}$ \\
\hline & & \multicolumn{2}{|c|}{ Paleocene } & $\begin{array}{l}\text { early } \\
\text { Oligocene? }\end{array}$ & $\begin{array}{l}\text { Limited to upper rise and lower slope; chiefly biogenous; fills channels on Cretaceous } \\
\text { surface; upper surface channeled; sampled at DSDP 605; cored but not recovered at } \\
\text { DSDP 612. }\end{array}$ \\
\hline 11 & & \multicolumn{2}{|c|}{ Maestrichtian } & Eocene & $\begin{array}{l}\text { Continuous from slope to rise: mixed terrigenous and biogenous: upper surface } \\
\text { channeled; onlap-and chaotic-fill; sampled at DSDP } 605,612 \text {; COST B-3. }\end{array}$ \\
\hline 12 & & \multicolumn{2}{|c|}{ Campanian } & Maestrichtian & $\begin{array}{l}\text { Continuous from slope to rise; chiefly terrigenous; upper surface channelled; onlap- } \\
\text { and chaotic-fill; sampled at DSDP } 612 ; \text { COST B-3. }\end{array}$ \\
\hline
\end{tabular}

Figure 3. A. Framework of stratigraphic sequences recognized in the study area. B. Stratigraphic relationships of sequences cored at DSDP drill sites compared to supersequences and global unconformities of the Vail model. Asterisk indicates $1 \mathrm{~m}$ of lower Oligocene sediment was cored at Site 612, resting unconformably between upper Miocene and upper Eocene strata. $1-6=$ global unconformities of the Vail model identified in cores. $\mathrm{a}-\mathrm{b}=$ global unconformities of the Vail model not identified in cores. $7=$ interregional unconformity of U.S. Atlantic margin not specified in the Vail model. Upper Oligocene, lower Miocene, and middle Miocene strata are known from other boreholes on the New Jersey shelf and slope (Poag, 1985a). See Poag and Low (this volume) for detailed discussion of all unconformities cored at Site 612.

Wilkens et al., this volume, and the Superlogs [back pocket]).

\section{STRATIGRAPHIC RELATIONSHIPS AT THE DSDP BOREHOLES}

\section{Site 612}

Site 612 was drilled on the middle part of the New Jersey Continental Slope $(1,404.3 \mathrm{~m}$ water depth) at $38^{\circ} 49.21^{\prime} \mathrm{N}, 72^{\circ} 46.43^{\prime} \mathrm{W}, 0.2 \mathrm{~km}$ northeast of the intersection of multichannel seismic Lines 25 and 34 (Fig. 1). This is also the intersection of single-channel Lines 69 and 89 (Figs. 2, 4-7). The stratigraphy of the borehole, as interpreted from lithology, microfossils, and downhole logging is accurately depicted by the seismic sequences and unconformities on these seismic lines (Figs. 4,6 ; direct correlation is provided by borehole travel- times recorded on the integrated sonic log; see Poag and Low, this volume).

Site 612 was drilled on the flank of a buried channel (Figs. 4, 6) and thus does not represent the normal stratigraphic succession of the New Jersey Slope. The thalweg of the channel as seen in transverse section (Line 89; Fig. 6) rests on an eroded surface of upper Eocene chalk, which causes a high-amplitude continuous reflection at $2.03 \mathrm{~s}$. Lower Oligocene strata form a thin horizontal layer that was entirely breached by the channel and barely was nicked by the core barrel. The channel fill consists of Tortonian, Messinian, and Pliocene sequences, each separated by an erosional unconformity (Poag and Low, this volume).

A similar channel can be seen ca. $12 \mathrm{~km}$ farther southwest on Line 89 (Figs. 7A, B) and another is present on dip Line 77 (6 km to the northeast), which crosses the 
B

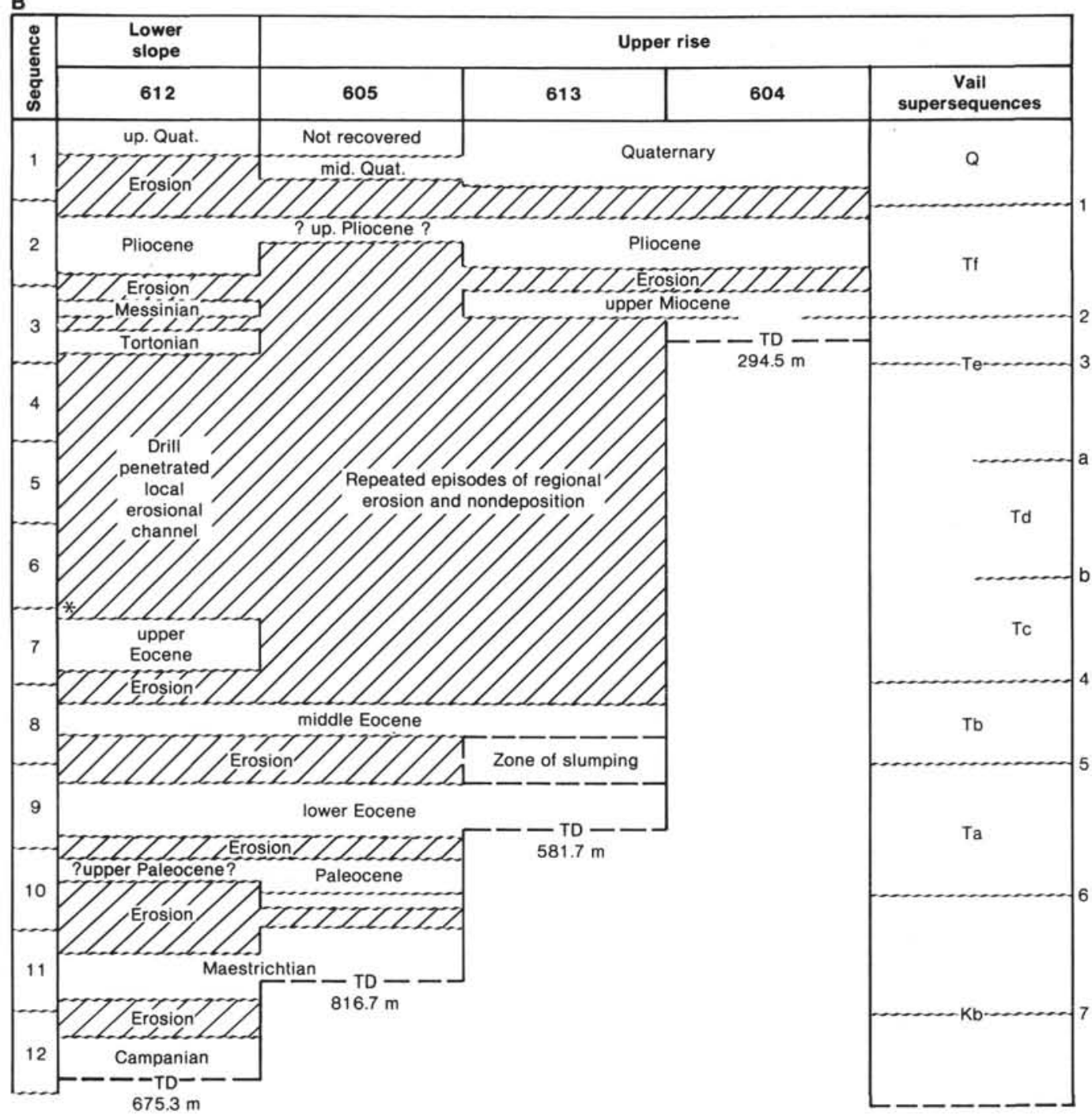

Figure 3 (continued).

COST B-3 and AMCOR 6021 boreholes (Fig. 8). The basal strata filling each channel appear to be of Tortonian age, and the youngest strata breached by the channels are Seravallian (middle Miocene). Thus, erosion of the channels took place near the Seravallian-Tortonian transition, presumably during a sea-level fall that Vail and Mitchum (1979) assert took place in the earliest Tortonian $(9.8 \mathrm{Ma})$. This erosion probably contributed detritus to the debris-flow deposit cored at the bottom of Hole 604 and at Site 613 on the adjacent upper rise (Fig. 2). Tortonian microfossils are abundant among the sands and conglomerates cored at these sites.

The single-channel dip lines show angular relationships (truncation and onlap) between reflections at the unconformable sequence contacts, which can be traced away from the borehole. They also depict nearly the same succession of unconformity-bound sequences drilled updip at the COST B-3 site (Figs. 2, 9A, B). The updip middle Miocene, lower Miocene, and upper Oligocene sequences are truncated upslope before reaching Site 612 . Lower Oligocene strata are limited to the outer part of the thick prism of slope strata seen on Lines 69 and 77 (Figs. 4, 8).

\section{Site 605}

Site 605 was drilled ca. $17 \mathrm{~km}$ downdip from Site 612 , on the toe of the upper-rise wedge ( $2197 \mathrm{~m}$ water depth) at $38^{\circ} 44.5^{\prime} \mathrm{N}, 72^{\circ} 36.6^{\prime} \mathrm{W}$. The site is ca. $0.5 \mathrm{~km}$ southwest of multichannel Line 25 and $0.2 \mathrm{~km}$ southeast of single-channel Line 75 (Figs. 1, 2). The youngest depositional sequence present at Site 605 is the Pleistocene, which can be divided (on seismic lines) into two units, A and B (Fig. 10). The upper unit, A, can be further subdivided into two seismic subunits (Fig. 10). These can be clearly seen on Line 75 (Figs. 10,11) and on intersecting Line 171 (Figs. 12A, B).

Pleistocene Units A and B were thoroughly cored and dated (planktonic foraminifers) at Site 604 as late and early Pleistocene, respectively (see below). The first core taken at Site 605, however, was recovered after washing to a depth of ca. $145.3 \mathrm{~m}$, and contained no strata younger than middle Pleistocene. Thus it is certain that the 


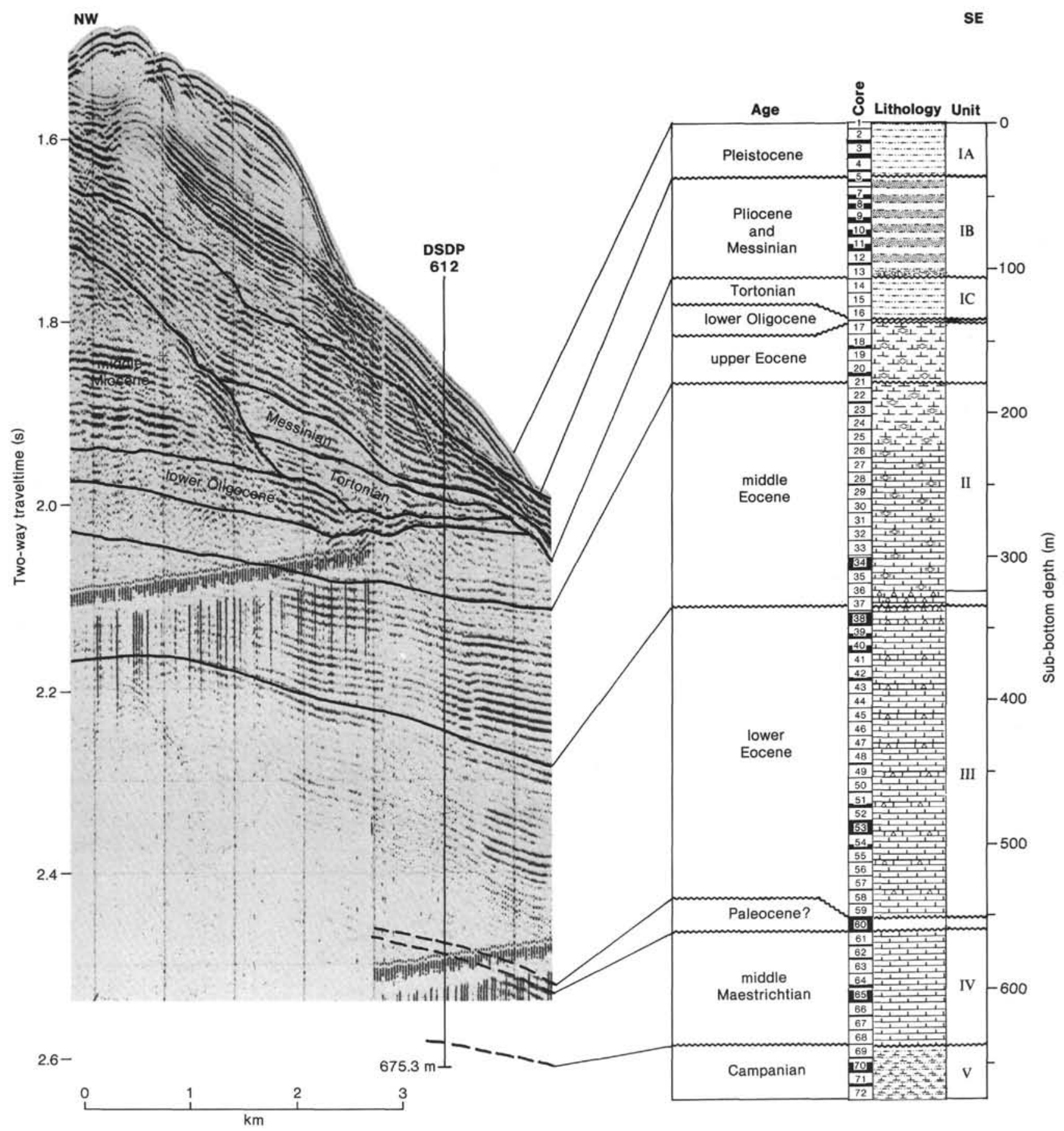

Figure 4. Stratigraphic column for Site 612 compared with dip section along single-channel seismic Line 69 . Line 89 (Fig. 7) crosses Line 69 at Site 612 (see Fig. 2). The middle Miocene sequence, sampled updip at the COST B-3 well, is truncated by erosion $1.6 \mathrm{~km}$ NW of Site 612 . Messinian and Tortonian strata fill a local channel cut into the upper Eocene surface (see Fig. 6). The lower Oligocene sequence also has been truncated and severely thinned.

first core recovered at Site 605 did not contain any of Pleistocene Unit A. The depth of $145 \mathrm{~m}$ (approximately top of Core 1) is at ca. $3.12 \mathrm{~s} \mathrm{(2-way} \mathrm{traveltime)} \mathrm{at} \mathrm{the}$ Site 605 projection on Line 75 (Fig. 10), which is within Pleistocene Unit B (top of Unit B is at $3.05 \mathrm{~s} \approx 90 \mathrm{~m}$ below the seafloor [BSF]). Its age of "middle" Pleistocene may correspond to the "early" Pleistocene of Unit B at Site 604, where no "middle" Pleistocene was cited.
On Line 75 (Fig. 10), a thin layer of Pliocene strata can be seen between 3.18 and $3.20 \mathrm{~s}$ at the Site 605 projection, as extrapolated from Sites 604 and 613 . The shipboard party of Leg 93 originally reported a thin biosiliceous layer of Pliocene age at approximately this depth at Site 605 (Sample 605-6-4, 125-144 cm; $198.4 \mathrm{~m} \mathrm{BSF),}$ below which is a coring gap of $3 \mathrm{~m}$; they later included this interval within the lower Pleistocene section. The 
A

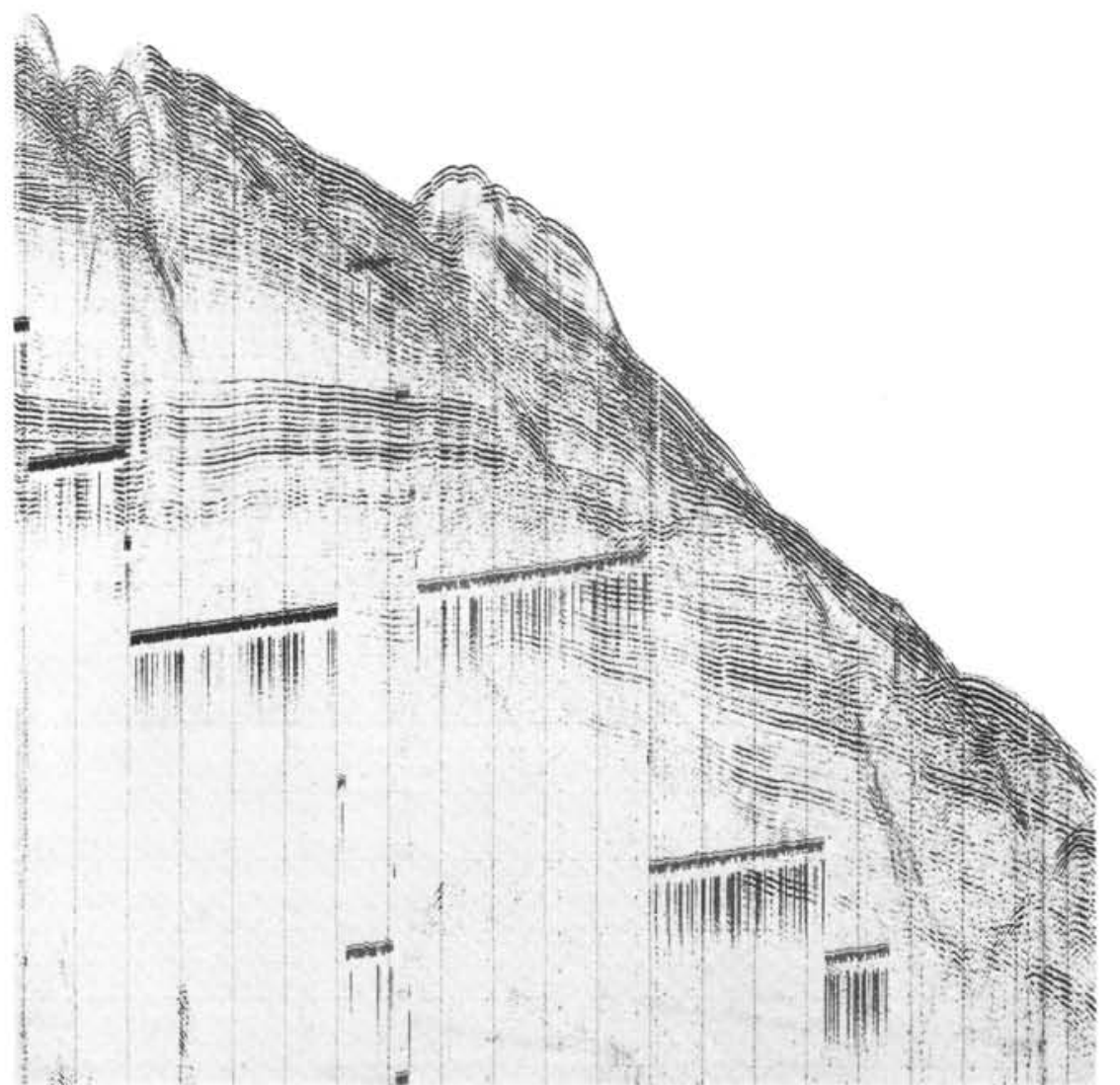

NW

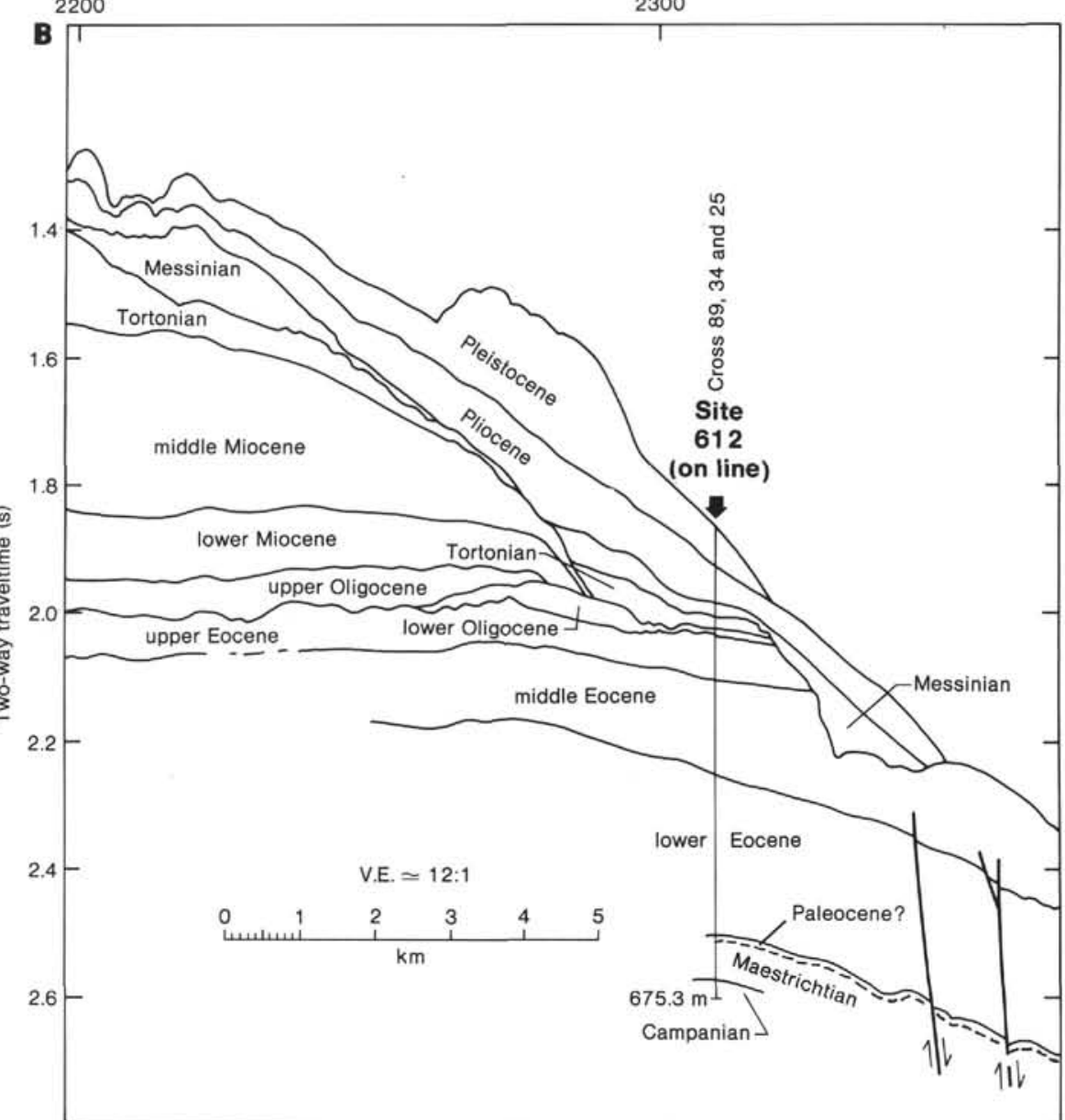

Figure 5. A. Uninterpreted segment of single-channel seismic Line 69. B. Interpretation of single-channel seismic Line 69. Note truncation of upper Oligocene, lower Miocene, and middle Miocene sequences updip from Site 612. Site 612 penetrated a local channel on the upper Eocene surface, which is filled by Tortonian, Messinian, and Pliocene strata. The Messinian strata also fill a (the same?) channel downdip from Site 612 where it excavates the middle Eocene surface. The lower Oligocene sequence appears to be completely eroded away $7 \mathrm{~km}$ NW of Site 612 . High-amplitude reflections near $2.49 \mathrm{~s}$ in Hole 612 appear to represent a thin Paleocene clay that was not recovered in the cores. 


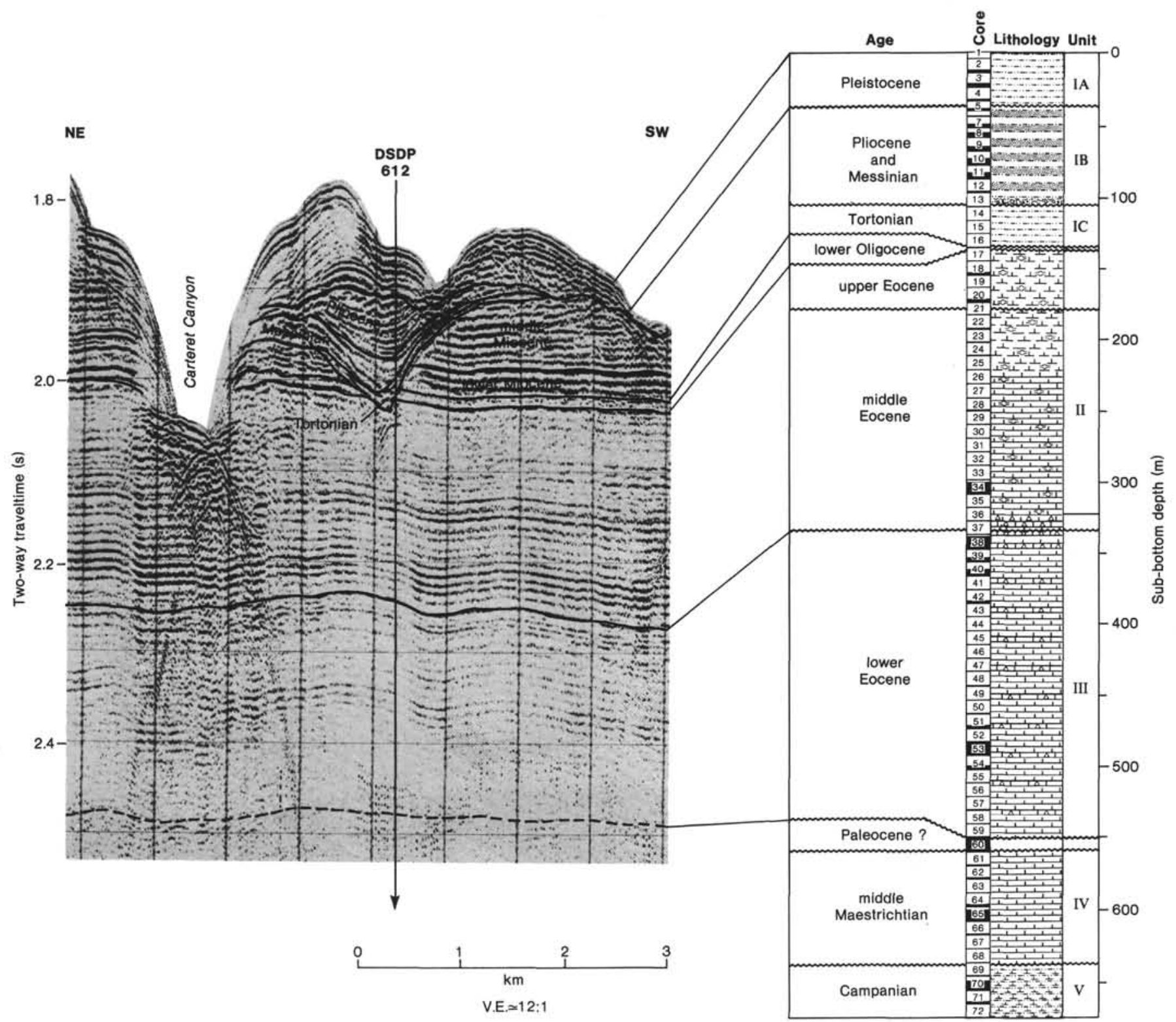

Figure 6. Stratigraphic column for Site 612 compared with strike section along single-channel seismic Line 89. This line crosses Site 612 parallel to the slope contours showing the downslope channeling on the upper Eocene surface. The channel whose SW margin was penetrated at Site 612 is a local feature, filled with Tortonian, Messinian, and Pliocene sediments before being more broadly blanketed by Pleistocene strata. Note that lower and middle Miocene strata, not present at Site 612, are well represented SW of the site. Middle Eocene strata appear to crop out in the walls and floor of Carteret Canyon.

Pliocene layer identified on Line 75 may have thinned to less than $2 \mathrm{~m}$ thickness at the drill site and could have been missed in the coring gap.

The top of the middle Eocene sequence is at $3.2 \mathrm{~s}$ at the projection of Site 605 on Line 75 (Fig. 10), which corresponds to a drilled depth of $202.3 \mathrm{~m}$ at the actual site. A wedge including upper Miocene strata overlying undrilled Sequence 7 is present on Line $75,1 \mathrm{~km}$ downdip from the Site 605 projection. In contrast, on Line 25 , only $0.5 \mathrm{~km}$ along strike to the northeast (Fig. 2), Sequence 7 extends updip beneath the projection of Site 605 . This contrast demonstrates the danger of using a single profile to interpret stratigraphic relationships in this highly complex area.
At the projection of Site 605 on Line 75 (Fig. 10), the top of the lower Eocene sequence is at $3.34 \mathrm{~s}$, corresponding to a depth of $350 \mathrm{~m}$ at the actual site. The top of the Paleocene is at ca. $3.56 \mathrm{~s}$ on Lines 25 and 75, and ca. $562 \mathrm{~m} \mathrm{BSF}$ at the drill site. The top of the Maestrichtian sequence is at $3.72 \mathrm{~s}$ on Line 25 and at $3.75 \mathrm{~s}$ on Line 75; it is at $759.8 \mathrm{~m} \mathrm{BSF}$ at the drill site.

Truncated and onlapping reflections at sequence boundaries depicted on Line 75 (Fig. 10) clearly indicate the same kinds of unconformable contacts characteristic of Site 612. Internal reflections within the sequences reveal that chaotic or disturbed bedding is commonplace; thicknesses vary dramatically in the dip direction as a result of differential erosion. 


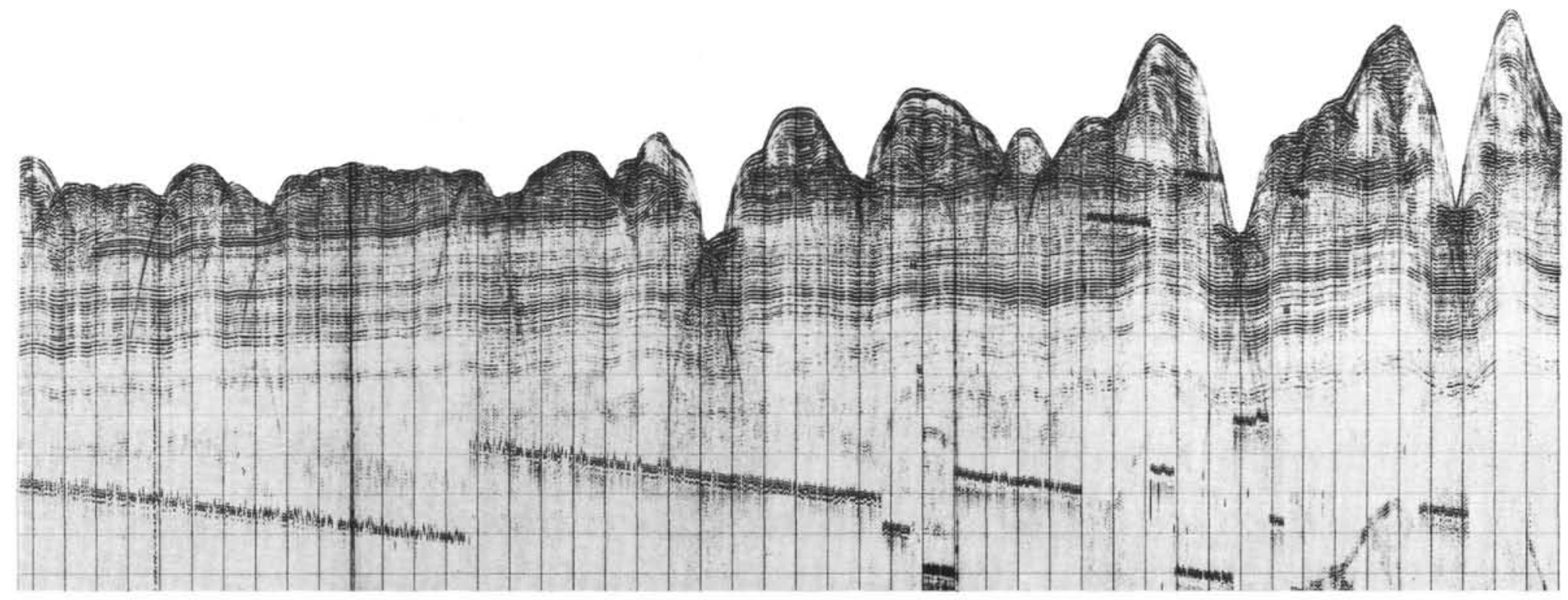

\section{B}

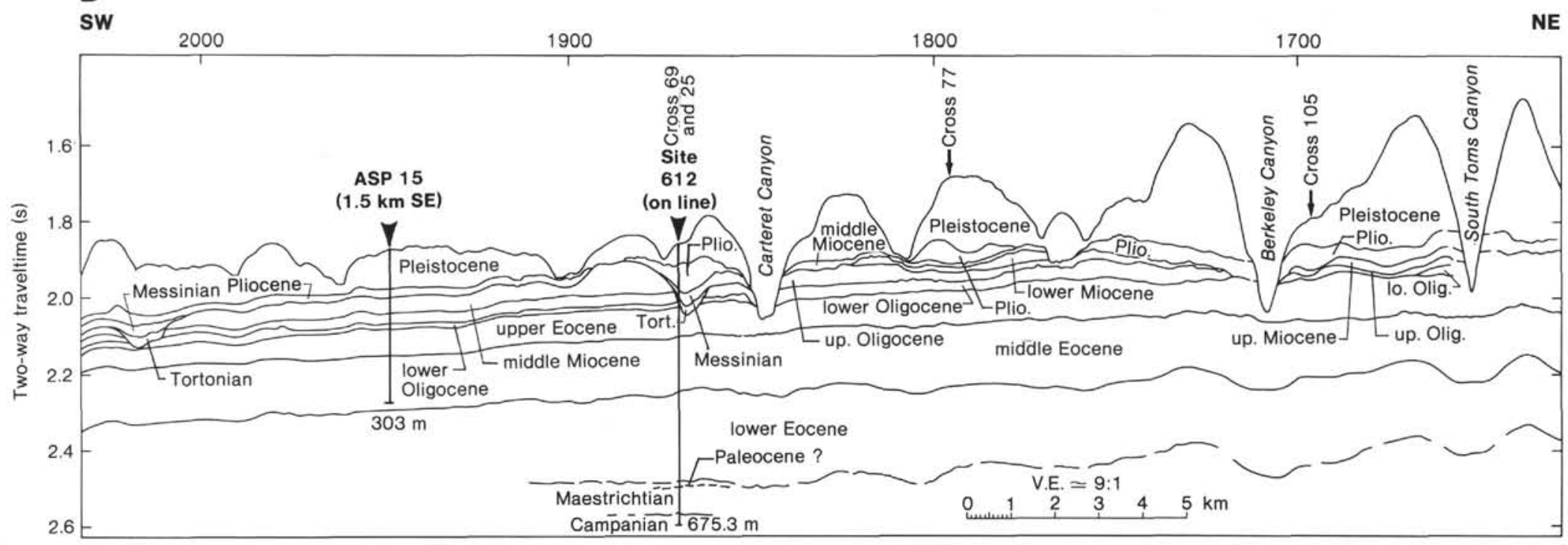

Figure 7. A. Uninterpreted segment of single-channel seismic Line 89. B. Interpretation of single-channel seismic Line 89. Note that a channel, of the same age and size as that drilled at Site 612, is present near the SW end of this line segment. A younger channel cuts the upper Oligocene surface $9 \mathrm{~km}$ NE of Site 612 , and three unfilled submarine canyons cut down to the upper Eocene surface. At this position on the lower slope, the post-Eocene sequences are much more complex and erratically distributed than the older sequences. 


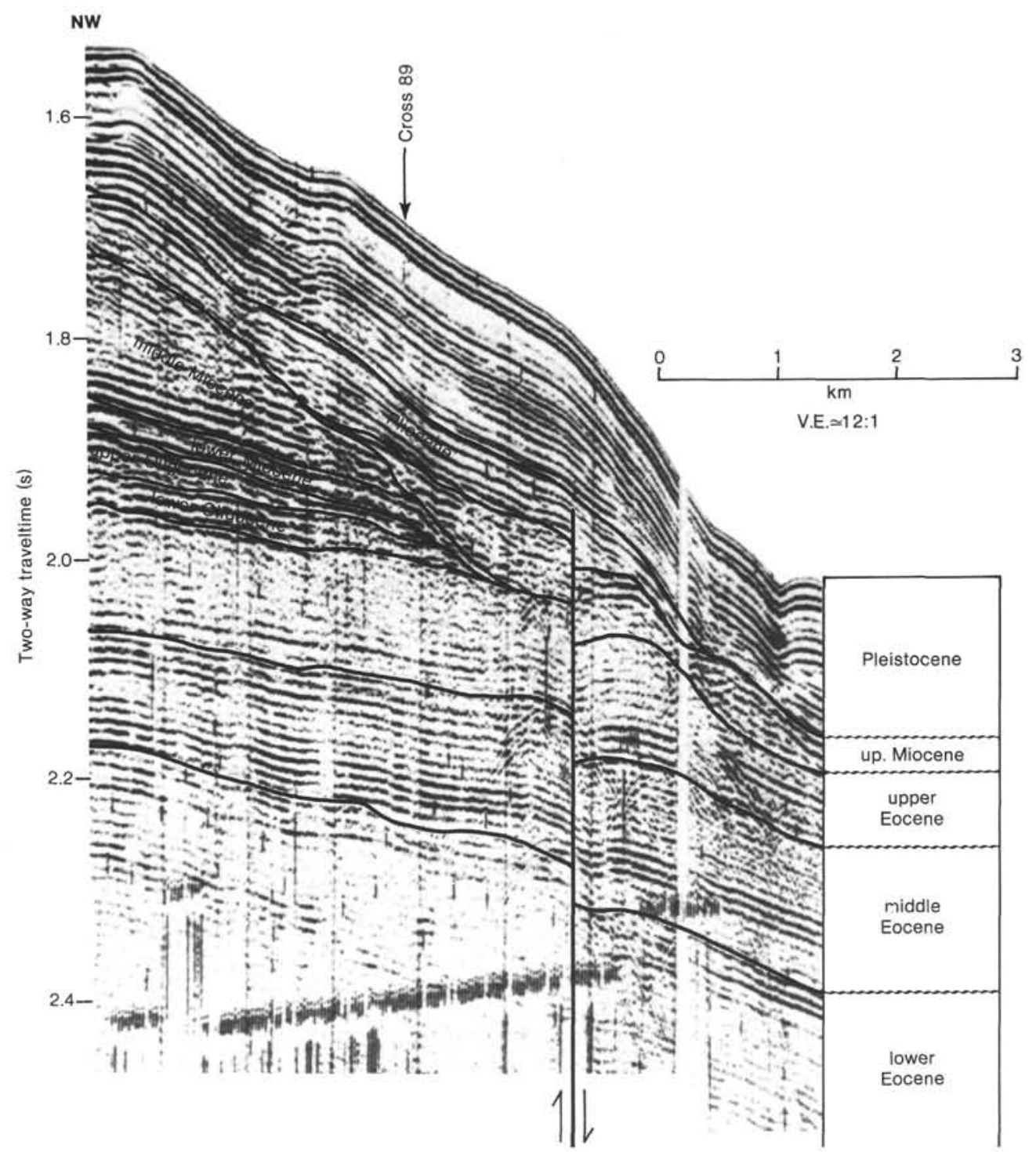

Figure 8. Illustration of an erosional channel on single-channel seismic Line 77, comparable to channels on Lines 69 and 89 . The lower Oligocene through middle Miocene sequences are truncated by the channel, which cuts down to the faulted upper Eocene surface. The channel is filled by upper Miocene sediments. Line 77 crosses the COST B-3 well site $9 \mathrm{~km}$ updip from the segment illustrated here (see Fig. 9b).

Faulting has been an important postdepositional process along Line 75 , where rollover oil a downthrown block is clearly displayed by middle Eocene reflections (Figs. $11 \mathrm{~A}, \mathrm{~B})$. The seismic characteristics and relationships seen on Line 75 are repeated on the other single-channel lines that cross this part of the margin (e.g., Line 105; Figs. 13A, B).

\section{Site 604}

Site 604 was drilled in 2364 water depth at $38^{\circ} 42.79^{\prime} \mathrm{N}$ and $72^{\circ} 32.95^{\prime} \mathrm{W}$ on the upper rise wedge. It is $0.8 \mathrm{~km}$ southwest of multichannel Line 25 , approximately on multichannel Line 35 , and $0.3 \mathrm{~km}$ northwest of singlechannel Line 170 (Figs. 1, 2). The site was selected to core through the center of a buried Miocene channel, but loose upper Miocene sands stopped penetration in the upper third of the channel fill.

The stratigraphic and lithofacies relationships of the drilled sequences are best expressed along Line 170 (Figs.
$14,15)$. Units A and B of the Pleistocene sequence are present at the projection of Site 604 on Line 170 (Fig. 14), where Unit A fills a shallow, moderately broad channel in the surface of Unit B. The two subdivisions of Unit A are also clearly seen (Figs. 14, 15).

The base of Unit A at the Site 604 projection on Line 170 (Fig. 14) is at $3.28 \mathrm{~s}(=98 \mathrm{~m} \mathrm{BSF})$. This falls within Core 93-604-11, which is dated as late Pleistocene. Unit B, whose top is in Core 93-604-12 (102 m BSF) is dated as early Pleistocene.

The top of the Pliocene is at ca. $150 \mathrm{~m} \mathrm{BSF}$ at the well site and at $3.35 \mathrm{~s}(161 \mathrm{~m})$ at its projection on Line 170 (Fig. 14). A truncated erosion surface forms the Pliocene/Pleistocene contact. The basal Pliocene section on Line 170 fills a broad shallow channel excavated into the underlying upper Miocene surface (Figs. 14, 15).

The top of the upper Miocene sequence at Site 604, a distinctive unconformity marked by a quartz-pebble conglomerate (239 m BSF; see Poag, 1985b), is a strongly 

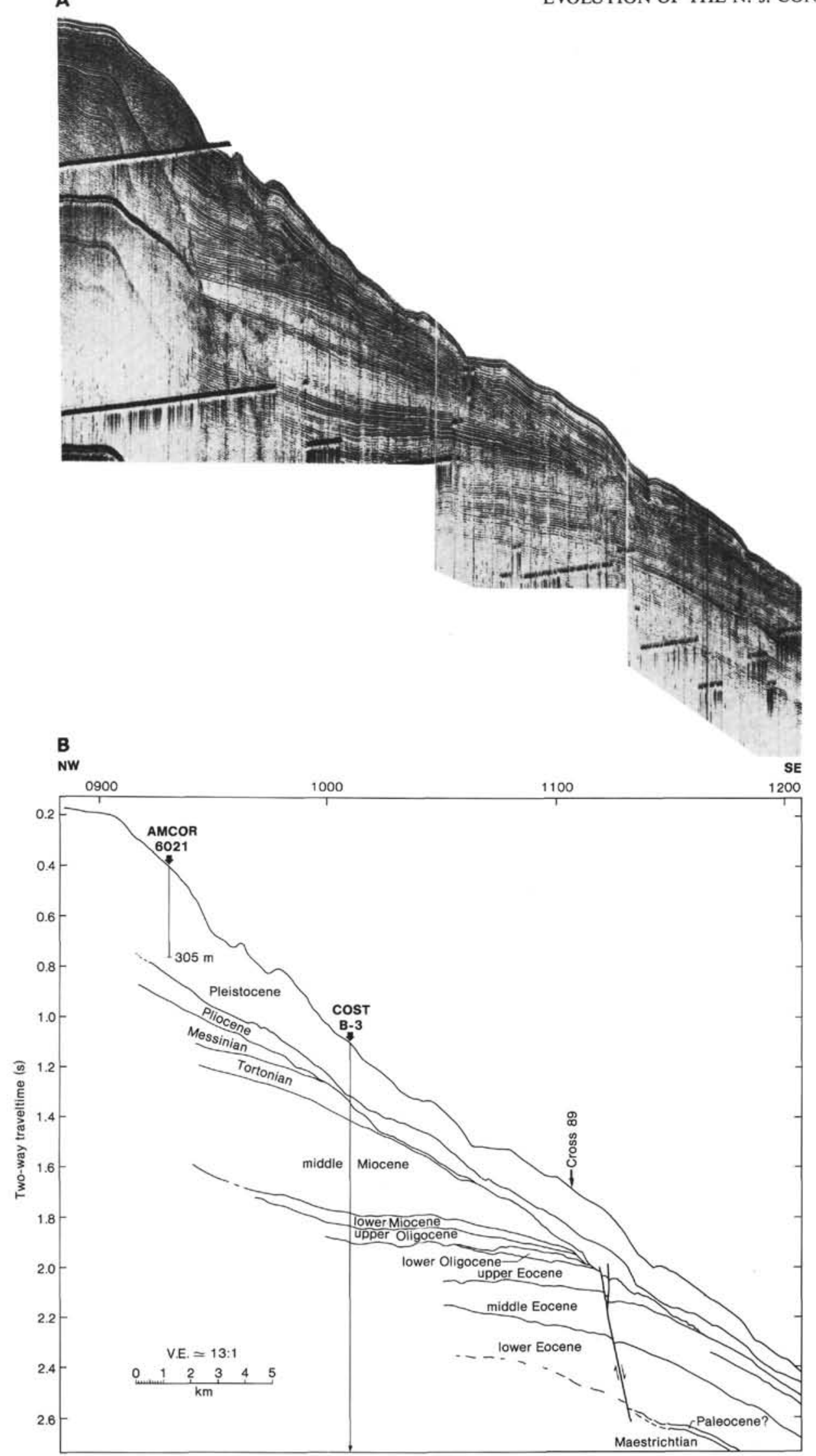

Figure 9. A. Uninterpreted segment of single-channel seismic Line 77. B. Interpretation of single-channel seismic Line 77. Note middle Miocene wedge truncated SE of COST B-3 well. Thin sliver of lower Oligocene strata is similar to that at Site 612 (Figs. 6, 7). See Figure 8 for details of upper Miocene channel-fill on faulted upper Eocene surface. 


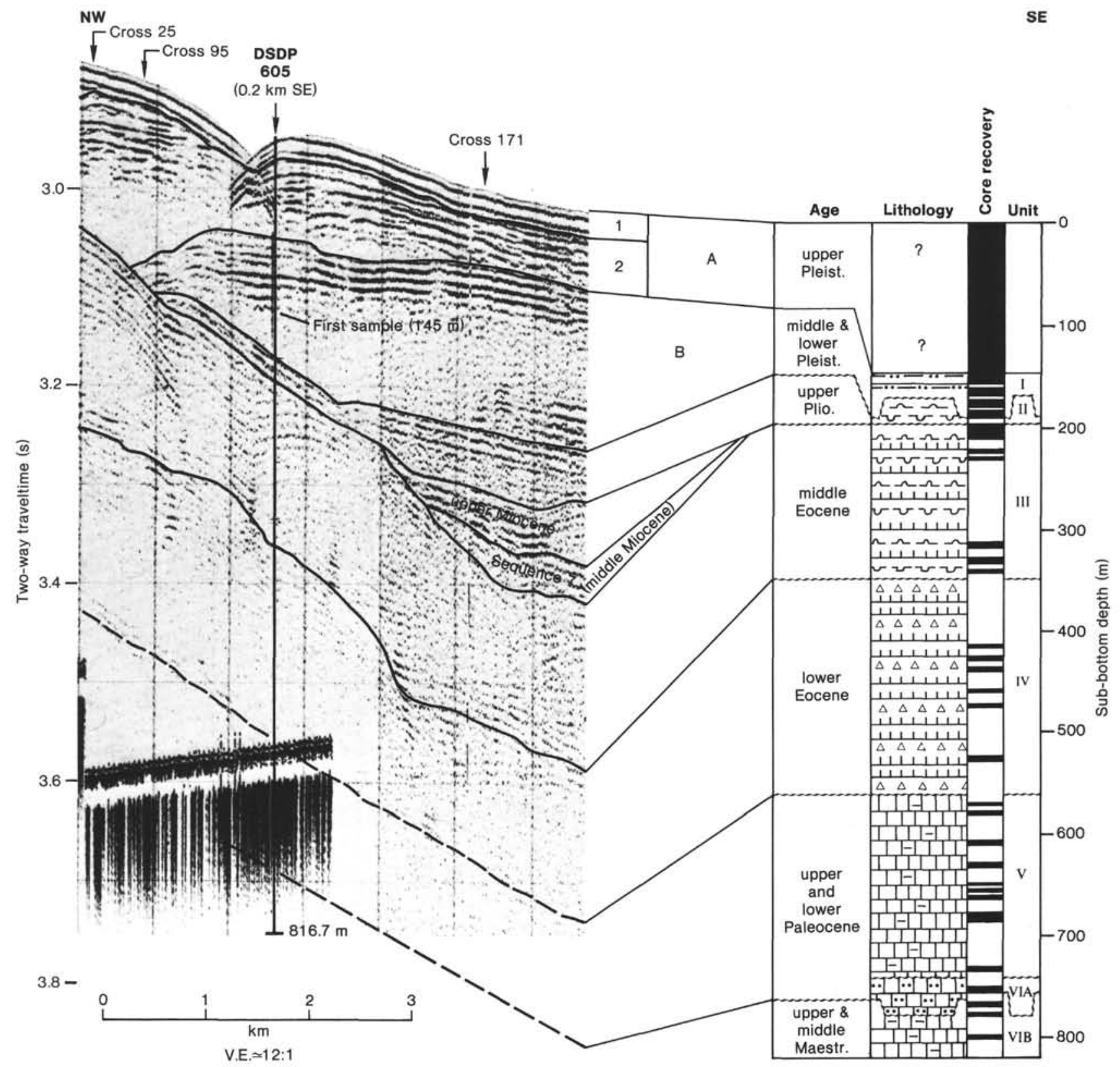

Figure 10. Stratigraphic column for Site 605 compared to its projection on single-channel seismic Line 75. Units A and B of the Pleistocene are well defined here; Unit B is truncated ca. $1 \mathrm{~km} \mathrm{NW}$ of Site 605 . The first sample retrieved at Site 605 came from Unit B. The thin tongue of Pliocene crossing the site was not recovered. Note that the upper Miocene sequence and Sequence 7 pinch out $1 \mathrm{~km}$ downdip from Site 605 .

truncated surface at $3.47 \mathrm{~s}$ at its projection on Line 170 (Figs. 14, 15). This upper Miocene sequence extends downward to $3.66 \mathrm{~s}$ at the Site 604 projection on Line 170 (base at $381 \mathrm{~m} \mathrm{BSF}$ ) and fills a deep channel. It fills somewhat broader, shallower channels to the northeast and southwest (Fig. 15). Updip, along Line 102 (see Fig. 17), the upper Miocene section thins to about one quarter of its thickness on Line 170.

Beneath the upper Miocene sequence, as seen on Line 170 (Figs. 14, 15), are two undrilled sequences (Sequences 6 and 7), below which are middle Eocene and lower eocene sequences. All of these sequences fill channels in underlying surfaces, and in turn, their surfaces are deeply channeled. The deepest channels are cut into the middle and lower Eocene sequences and into Sequence 7. Contorted or chaotic reflections, common in all the sequences along Line 170 (Figs. 14, 15), emphasize the ubiquity of sediment displacement from upslope sources. Similar relationships are developed along Line 102, where an additional undrilled sequence (Sequence 5) is present (see Fig. 17).

\section{Site 613}

Site 613 was drilled in $2323.2 \mathrm{~m}$ water depth at $38^{\circ} 46.26^{\prime} \mathrm{N}, 72^{\circ} 30.43^{\prime} \mathrm{W}$, on the upper rise wedge, 1.6 $\mathrm{km}$ northwest of multichannel Line 35 and $6.7 \mathrm{~km}$ 

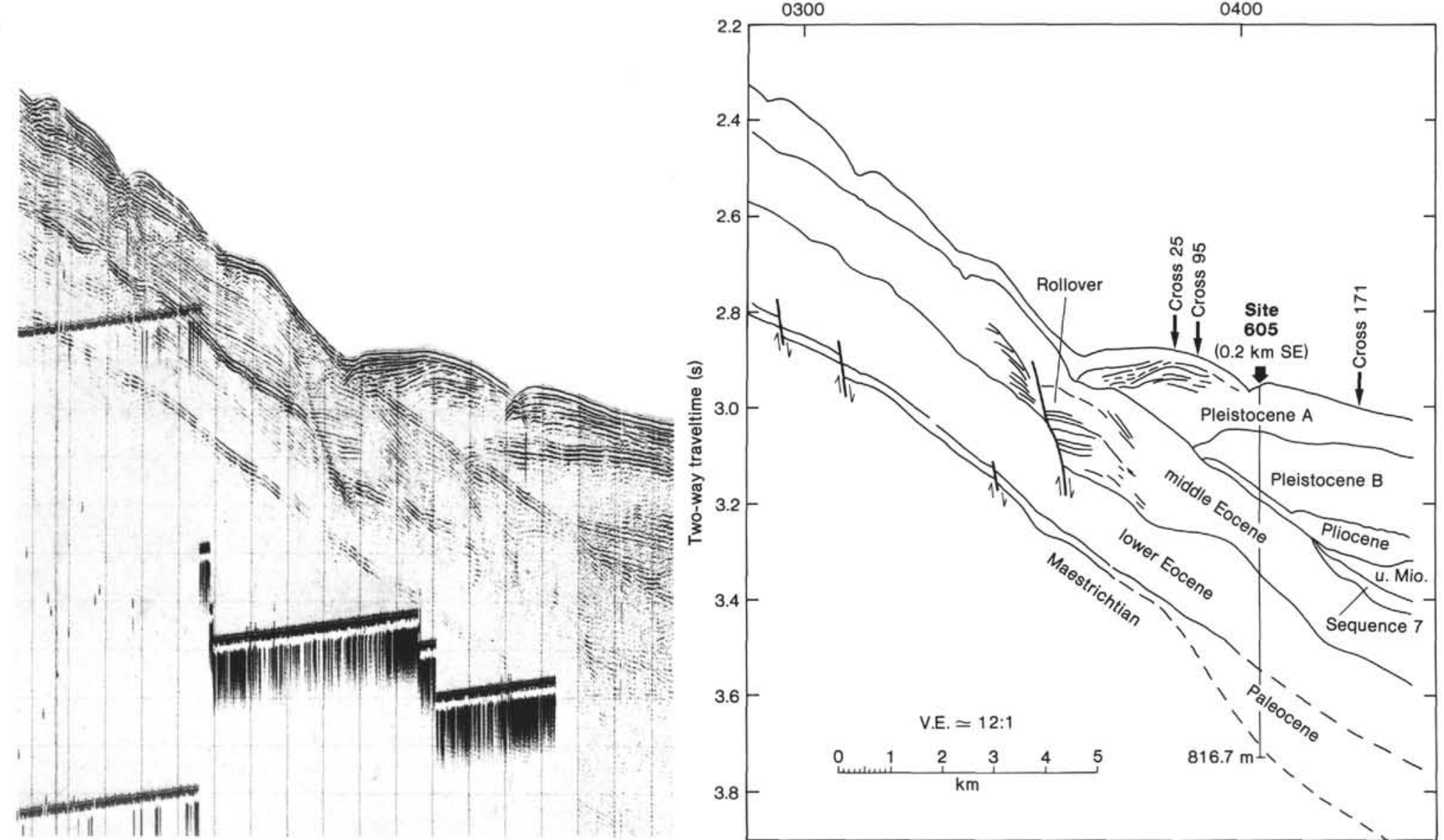

Figure 11. A. Uninterpreted segment of single-channel seismic Line 75. B. Interpretation of single-channel seismic Line 75. Note Pleistocene Units A and B and pinchouts of upper Miocene sequence and Sequence 7. All younger sequences onlap the eroded middle Eocene surface. Lower beds of the middle Eocene sequence form a rollover structure on the downthrown block of the normal fault $4 \mathrm{~km} \mathrm{NW}$ of Site 605. Triplet of high-amplitude reflections near base of section appears to come from a thin tongue of Paleocene strata (cf. Fig. 5b). 

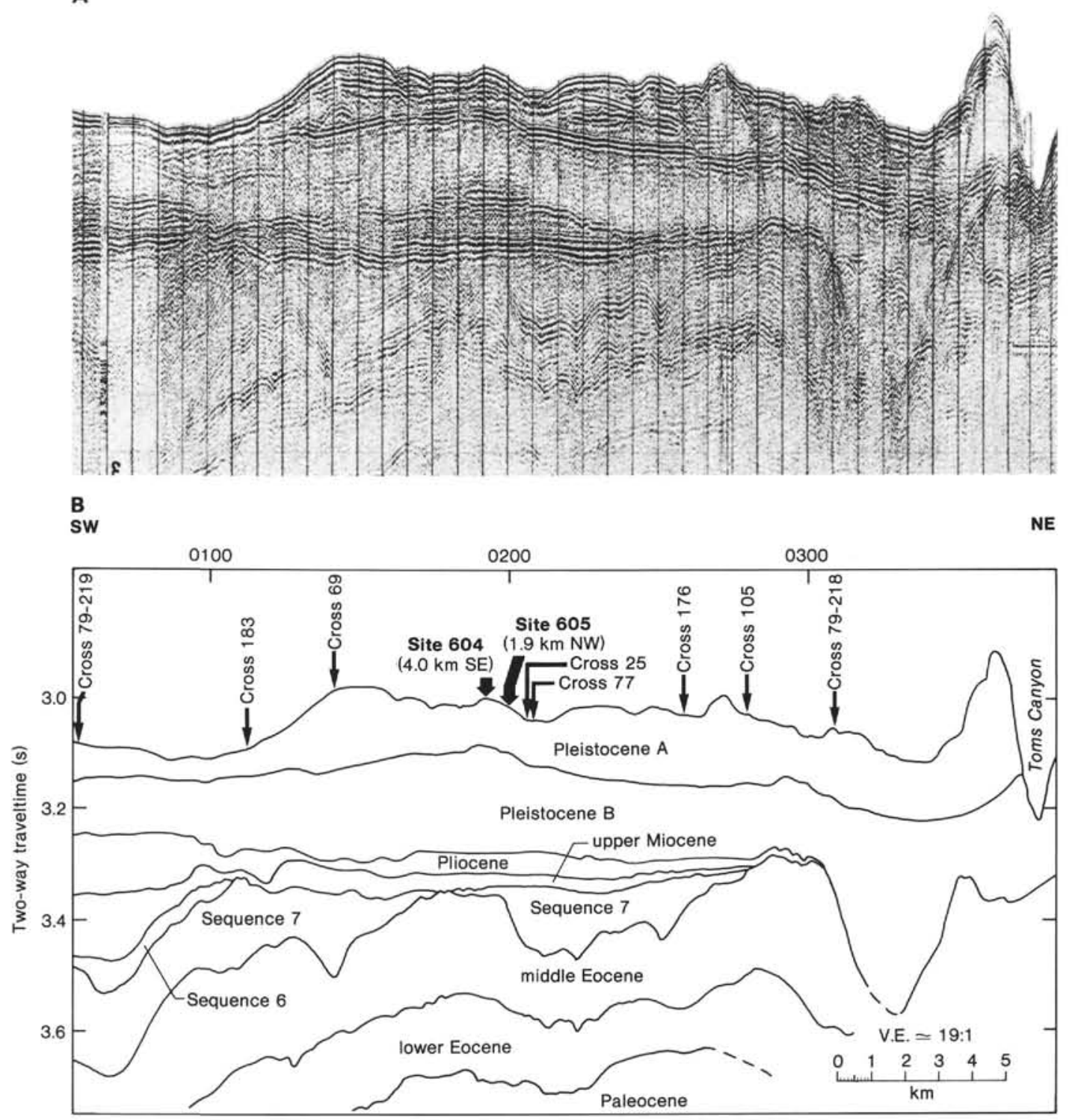

Figure 12. A. Uninterpreted segment of single-channel seismic Line 171. B. Interpretation of single-channel seismic Line 171. This strike line demonstrates the multiple episodes of erosional channeling that characterize the study area. Sequence 7 fills two deep and broad channels cut into the middle Eocene surface. An even deeper channel, NE of the intersection with Line 79-218, is filled entirely with Pleistocene strata. Channeling on the post-middle Eocene surfaces is significantly less severe, except for the present seafloor.

northeast of multichannel Line 25 (Fig. 1). It is also located $0.2 \mathrm{~km}$ southwest of single-channel Line $105,0.4$ $\mathrm{km}$ northwest of its intersection with single-channel Line 102 (Fig. 2).

On Lines 105 and 102 , the stratigraphic sequences identified at Site 613 are sharply defined by the seismic sequences (Figs. 13A, B; 16, 17). Direct correlation was made by using the integrated sonic log obtained at Site 613 (see Poag and Low, this volume). The unconformable sequence contacts are defined by seismic facies changes and angular relationships between reflections (truncation and onlap). The two Pleistocene units, A and B, are particularly well developed along both Lines 102 and 105 (Figs. 13, 16, 17) and are separated by an unconformable contact at $3.22 \mathrm{~s}$ (ca. $92 \mathrm{~m}$ BSF; Fig. 16), which occurs in a part of Hole 613 that was washed through and not logged. The two subdivisions of Unit A are also differentiated here (Figs. 13, 16). The surficial subunit $\left(A_{1}\right)$ is expressed as a series of parallel, continuous, high-amplitude reflections that drape the underlying topography. The lower subunit has a rugged upper surface and contains chiefly chaotic, poorly defined reflections.

The top of Pleistocene Unit B is marked by a series of high-amplitude, parallel, continuous reflections (Fig. 16) that grade downward into a thicker section, which is semitransparent, signifying uniform lithology. At the well site this uniform facies begins at the top of lithologic Unit IB (119 m BSF), an unbedded, homogeneous mud.

The top of the Pliocene sequence is at $3.35 \mathrm{~s}$ on Line 105 (3.36 s on downhole log); a series of parallel, subcontinuous, moderately high-amplitude reflectors are 
A

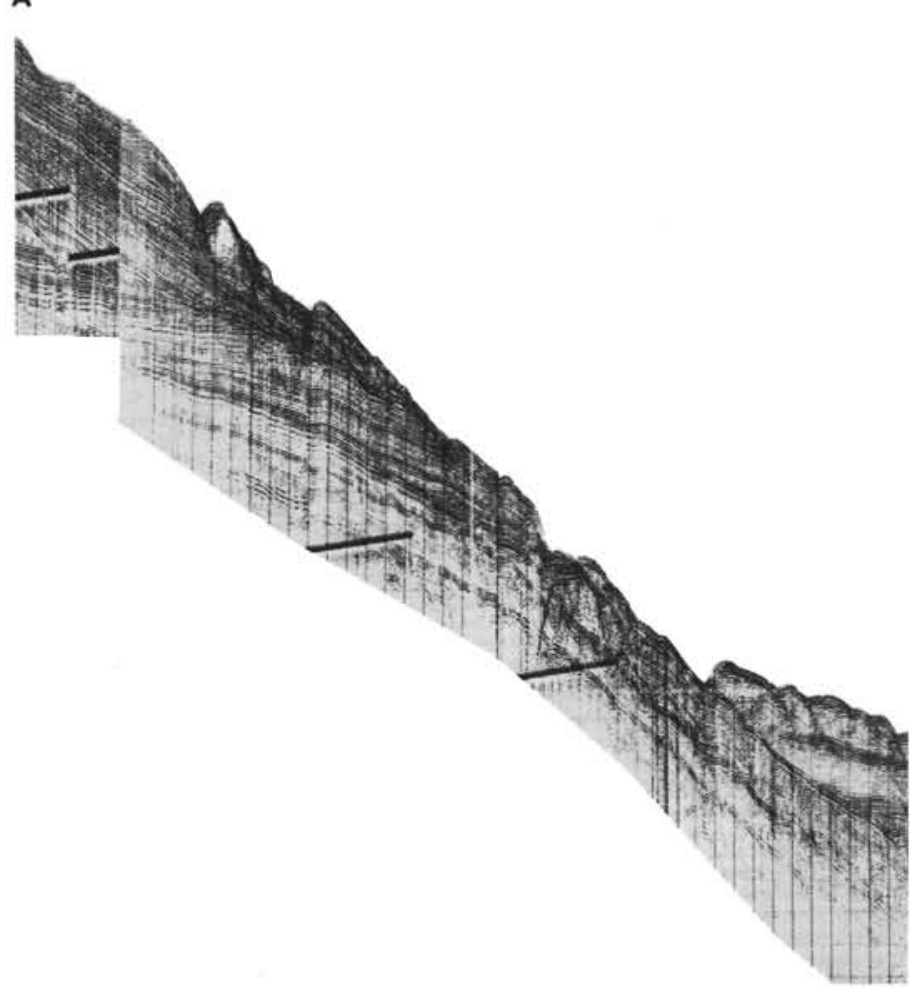

NW

$1200 \quad 1300 \quad 1400 \quad 1500$

SE

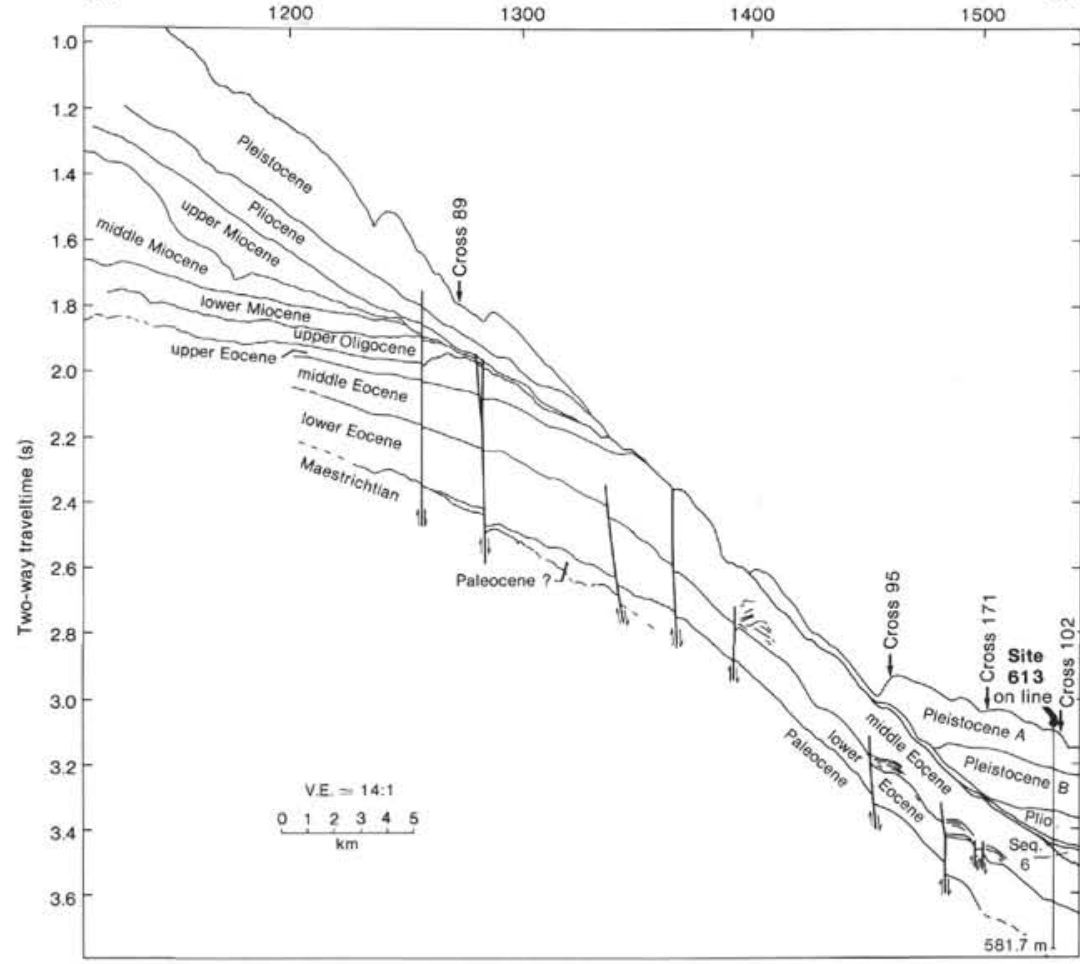

Figure 13. A. Uninterpreted segment of single-channel seismic Line 105. B. Interpretation of single-channel seismic Line 105. This dip line nearly crosses Site 613 and shows stratigraphic relationships on either side of the middle Eocene outcrop belt (seen near center of figure). To the NW, upper Oligocene through middle Miocene sequences thin or are truncated updip from the intersection with Line 69 . These units are then downlapped by upper Miocene through Pleistocene sequences, which terminate downdip at shotpoint 1350 . Sequence 6 and younger sequences onlap the eroded middle Eocene surface to the SE. Normal faults are common in the Eocene sections. 


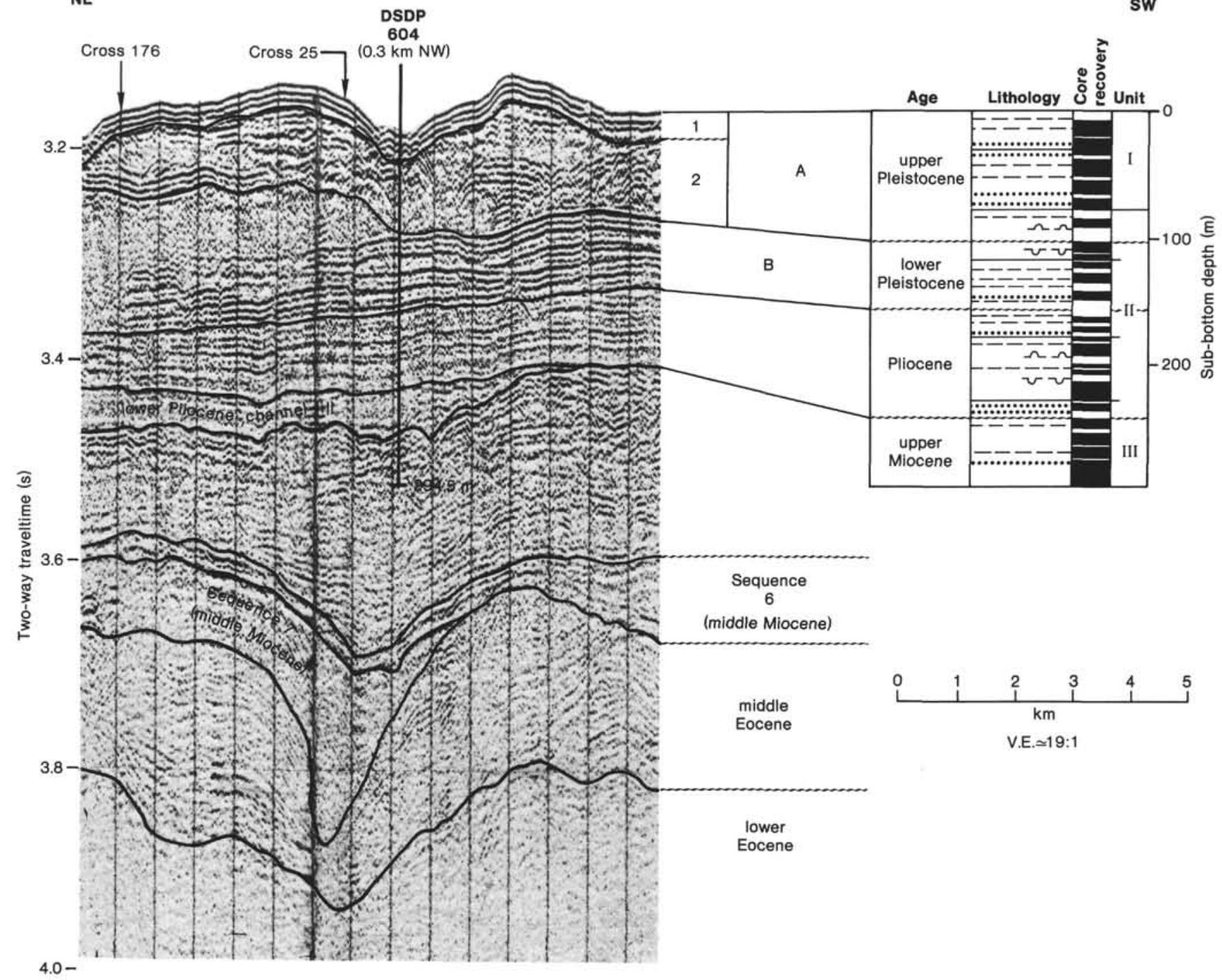

Figure 14. Stratigraphic column for Site 604 compared with its projection onto single-channel seismic Line 170. Units A and B of Pleistocene are well represented here, as well as the subunits 1 and 2 of Unit A. Note the erosional truncations of reflections along the upper surface of Unit B. The lower part of the Pliocene sequence is a thin channel-fill deposit. Note the deep channel on the middle Eocene surface, filled with Sequence 7.

characteristic (Figs. 13, 16). A thin tongue of this unit onlaps the slope face for several kilometers updip from Site 613 (Fig. 16).

The thin upper Miocene sequence begins at $3.44 \mathrm{~s}$ on Line 105 (Fig. 16; $3.36 \mathrm{~s}$ on downhole $\log$ ) marked by three high-amplitude, continuous, parallel reflections that are onlapped by the overlying Pliocene reflections. Below the upper Miocene sequence is one of the undocumented sequences (Sequence 6), a wedge-shaped unit terminating at or just downdip from Site 613. Sequence 6 should have been penetrated by Core 613-20, but Core 20 contained only a core catcher sample, which came from the underlying, calcareous, middle Eocene sequence.

A thick middle Eocene sequence begins at $3.46 \mathrm{~s}$ on Line 105 (3.46 s on the downhole log); its upper surface is marked by truncated reflections that are particularly prominent updip from Site 613 (Fig. 16). Moderately high-amplitude, subcontinuous, parallel-to-convergent, often sinuous, reflections characterize the middle Eo- cene sequence on Line 105 . We infer that the complex reflection patterns within the middle Eocene sequence are caused by slumping and other types of downslope mass movement of sediment. Especially notable are the normal faults that cut the lower part of the Eocene section and the several channels along its basal contact (Figs. $13,16)$.

The lower Eocene sequence begins at $3.63 \mathrm{~s}$ on Line 105 (Fig. 16; $3.63 \mathrm{~s}$ on downhole log), but is not marked by a sharply defined contact (this depth is near the maximum depth of resolution of the single-channel seismic system). Updip, however, its upper part is characterized by a series of very-high-amplitude reflections that presumably result from the porcellanitic diagenetic front, which was drilled at Site 613 (also at 605 and 612). Below these strong upper reflections, the lower Eocene sequence is semitransparent, or contains chaotic, poorly defined reflections (Figs. 13, 16). The upper surface of the sequence is irregularly channelled and faulted. Hole 
A

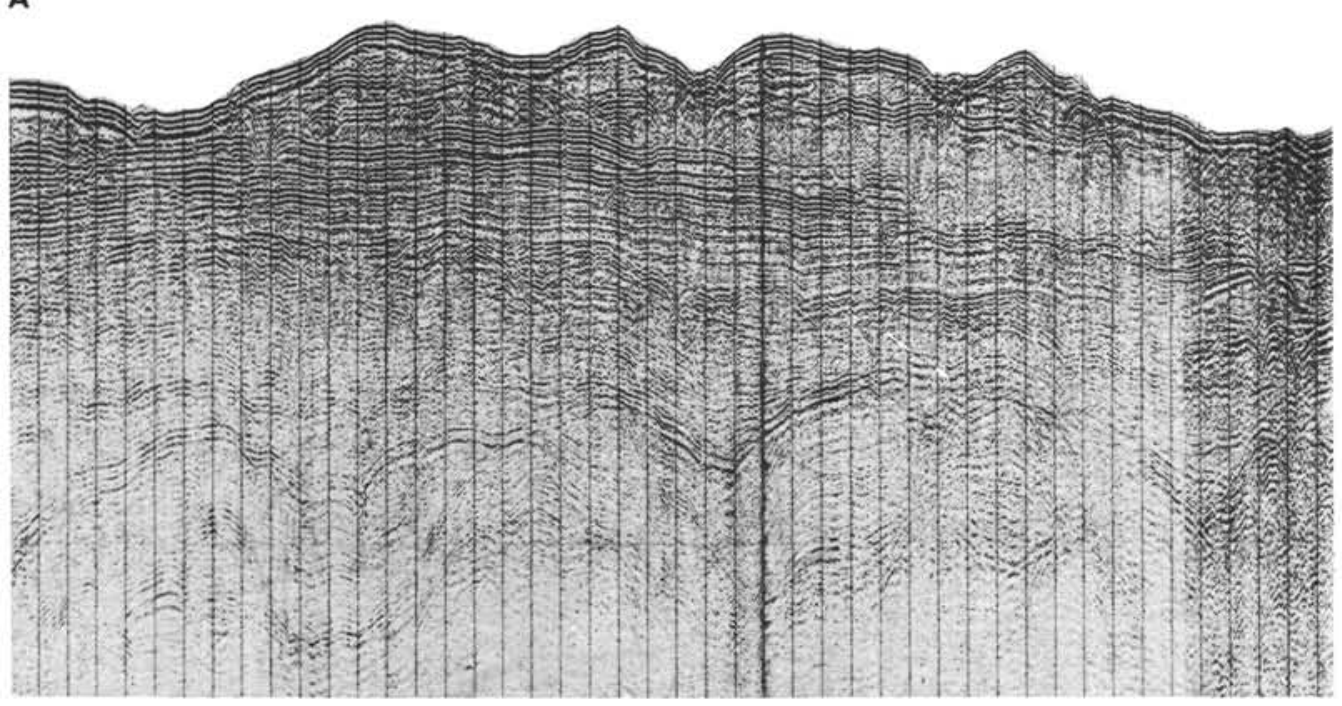

B

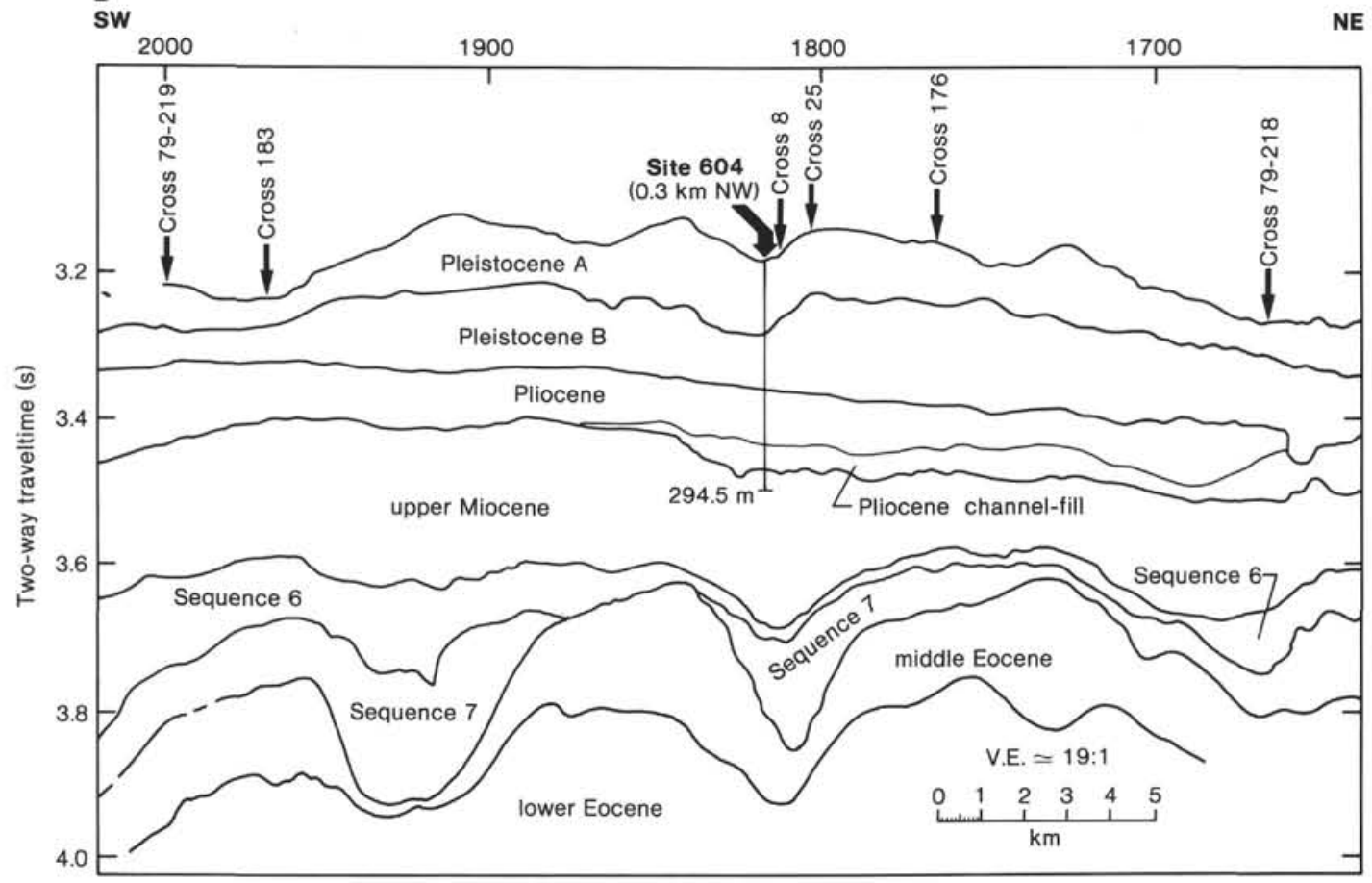

Figure 15. A. Uninterpreted segment of single-channel seismic Line 170. B. Interpretation of single-channel seismic Line 170. The line has been reversed in relationship to Fig. 14 in order to conform to the orientation of other strike lines. Note that the deepest channels are cut into the middle Eocene sequence and filled with undated Sequence 7. A hole drilled to the Eocene section, $3 \mathrm{~km}$ SW of Site 604, would have missed Sequence 7, which is absent there on the interchannel ridge.

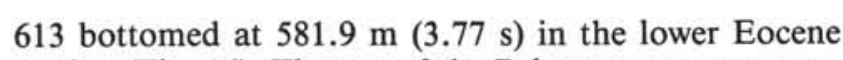
section (Fig. 16). The top of the Paleocene sequence appears to be only a few meters deeper (ca. $3.9 \mathrm{~s}$ ).

Line 102 intersects Line $105 \mathrm{ca} .0 .2 \mathrm{~km}$ downdip from Site 613 (Fig. 2) and reveals the stratigraphic relationships along strike (Figs. 17A, B). The surficial subunit of Pleistocene Unit A forms a fairly uniform drape over most of the line segment illustrated. It is interrupted and thinned by erosion, however, near its intersection with Line 183 (Figs. 18A, B). The buried surface of the lower subunit $\mathrm{A}_{2}$ has a relatively high topographic relief, caused in part by a series of downslope erosional channels that clearly truncate flanking reflections. Subunit $A_{2}$ is entirely eroded away near the intersection of Line 102 with Line 183 (Fig. 17), where Subunit $A_{1}$ fills channels cut into the surface of Unit B.

Pleistocene Unit B is rather uniformly thick at the center and northeast end of Line 102 (Fig. 17), but its upper part has been severely eroded beneath the intersections with Lines 183 and 79-219. Unit B fills a few small channels in the underlying Pliocene surface and sharply truncates upper Pliocene reflections in several 


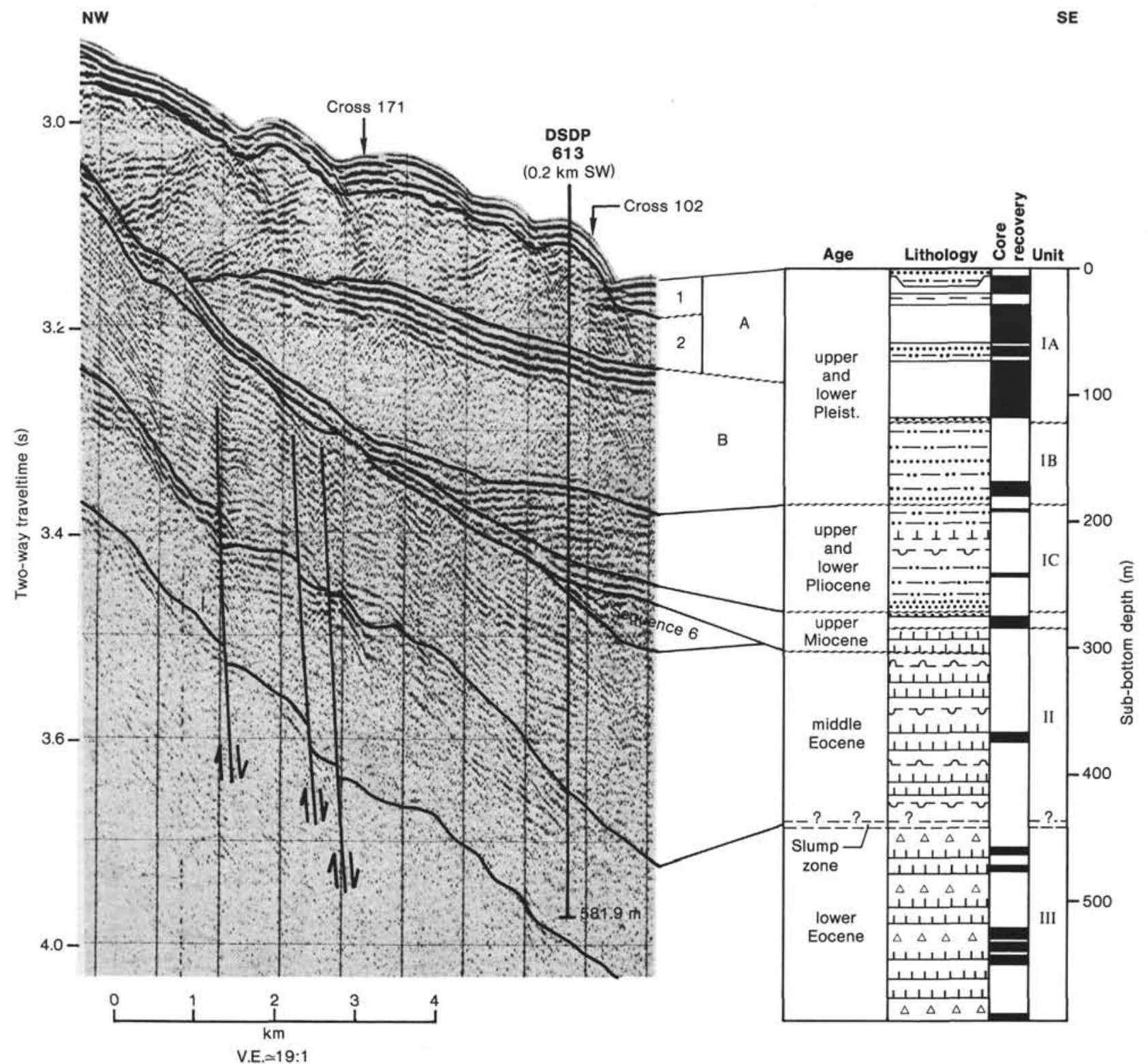

Figure 16. Stratigraphic column for Site 613 compared with single-channel seismic Line 105. Pleistocene Units A and B are well represented here, separated by an erosional unconformity. The Pliocene thins rapidly updip from Site 613, and the upper Miocene is a thin updip tongue where penetrated by the drill. The feather edge of Sequence 6, of unknown age, was penetrated, but not sampled, because of poor recovery in Core 20. Note the sinuose, truncated, and faulted reflections in the Eocene sequences. All the sequence boundaries are unconformities.

places. Angular relationships among internal reflections attest to additional downslope sediment movement and channelling during the Pliocene.

The upper Miocene sequence is relatively thick (ca. $175 \mathrm{~m}$ ) to the southwest in Figure 17, and fills several broad channels before thinning to less than $10 \mathrm{~m}$ at the intersection with Line 105 . Arched and chaotic reflections within the upper Miocene sequence reflect the results of downslope mass sediment flow. Truncation of upper reflections is evident in several places and is responsible in part for the northeastward thinning of the sequence.

The undrilled Sequence 6 is thin and poorly defined on Line 102, but can be traced over most of the profile segment with the help of intersecting lines. It appears to be completely missing over the top of a sediment mound to the southwest of center in Figure 17.

The next older sequence at the Site 613 projection on Line 102 is the thick middle Eocene chalk (Fig. 17). It can be traced southwestward across the line, where it thins, and is deeply incised (as deep as $200 \mathrm{~m}$ ) by erosional channels. These channels are filled by the undrilled Sequence 7, whose age is not certain. Sequence 7 is prominent in this region of the upper rise and can be traced widely to the southwest of Site 613 .

The top of the lower Eocene is too deep to show up clearly on most of Line 102, but it can be identified at the Site 102 projection (Fig. 17) and traced with moder- 
A
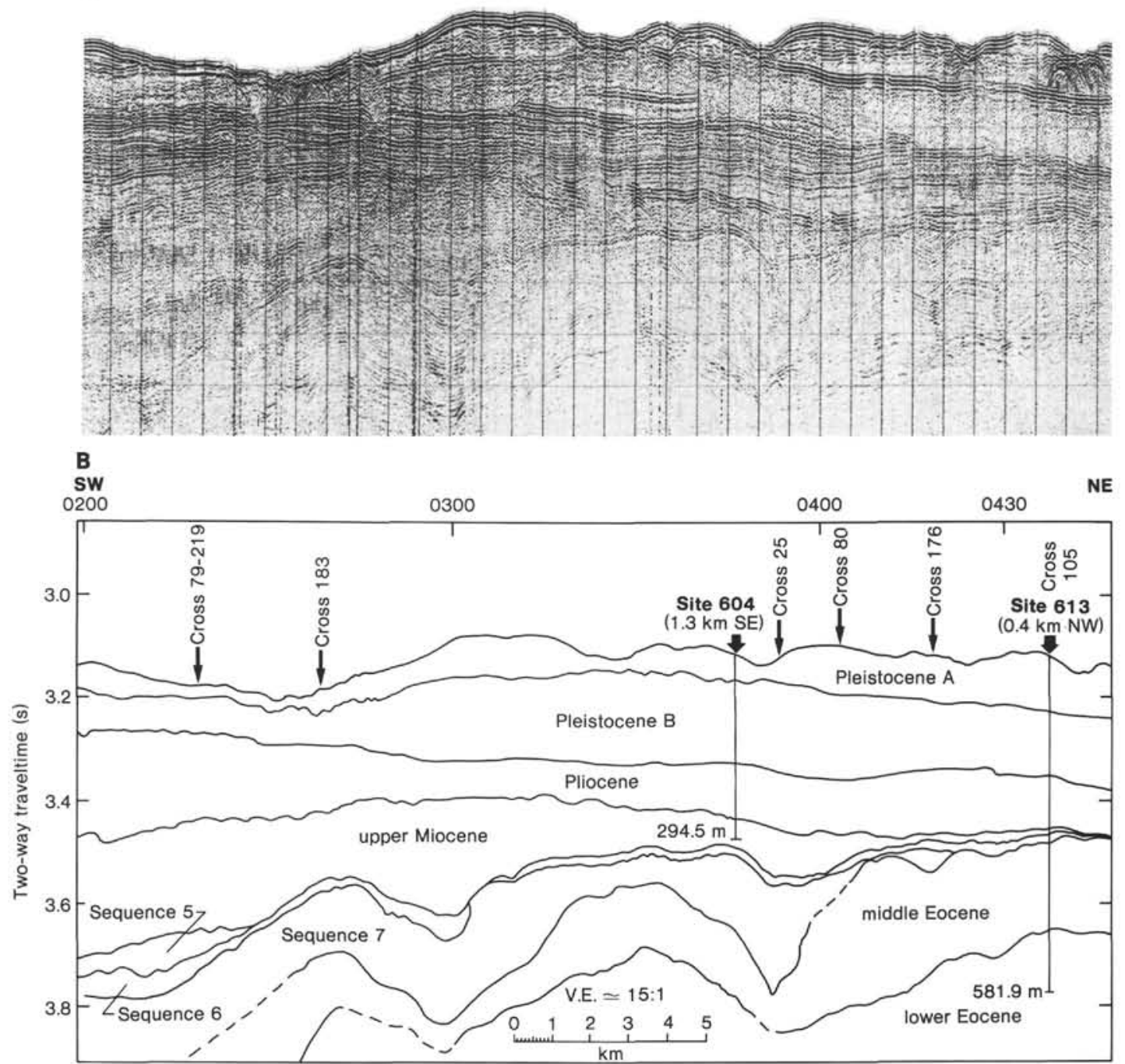

Figure 17. A. Uninterpreted segment of single-channel seismic Line 102. B. Interpretation of single-channel seismic Profile 102. This strike section passes $0.4 \mathrm{~km} \mathrm{SE}$ of Site 613 and illustrates the complicated series of stratigraphic units in the vicinity. The middle Eocene surface is deeply channeled and filled with unsampled Sequence 7, which along with Sequence 5, does not reach the projection of Site 613 . Sequence 6 does cross the Site 613 projection, but is not present at the actual site. Note the extreme NE thinning of the upper Miocene sequence (only $12 \mathrm{~m}$ thick at Site 613).

ate confidence to the southwest, with the help of intersecting line. Its upper surface is rugged, having been dissected by several erosional channels.

\section{EXTRAPOLATION OF DRILLED STRATIGRAPHY ACROSS THE UPPER RISE}

\section{Single-Channel Seismic Grid}

We analyzed four additional strike lines (Line 101, Appendix Figs. 1A, B; Line 173, Appendix Figs. 2A, B; Line 172, Appendix Figs. 3A, B; Line 178, Appendix Figs. 4A, B) and one additional dip line (Line 176, Appendix Figs. 5A, B) to illustrate more completely the complex stratigraphy and facies of the Cenozoic deposits in the vicinity of the upper-rise boreholes. These lines confirm the widespread occurrence of three of the un- drilled depositional sequences, Sequences 5,6 , and 7 , which Poag (1985b) tentatively assigned ages of late Oligocene, early Oligocene, and late Eocene, respectively (Fig. 3). Sequences 5 and 6 are thin or absent in updip sections (Lines 171, 101, 102), especially in the central parts of the strike lines (Figs. 12A, B; 17A, B; Appendix $1 \mathrm{~A}, \mathrm{~B})$. Sequence 6 begins to thicken in two lateral channels on Line 173 (Appendix Figs. 2A, B), and continues to expand in these channels, eventually covering the central region as well, on Lines 172 (Appendix Figs. 3A, B) and 178 (Appendix Figs. 4A, B).

Sequence 7 is the thickest of the undrilled units, especially where it fills two principal channels that can be traced from Line 171 (Figs. 12A, B) to Line 172 (Appendix Figs. 3A, B). On Line 178 (Appendix Figs. 4A, B), the channels are less distinct, and Sequence 7 is relatively uniform in thickness across the profile. 
C. W. POAG, G. S. MOUNTAINA
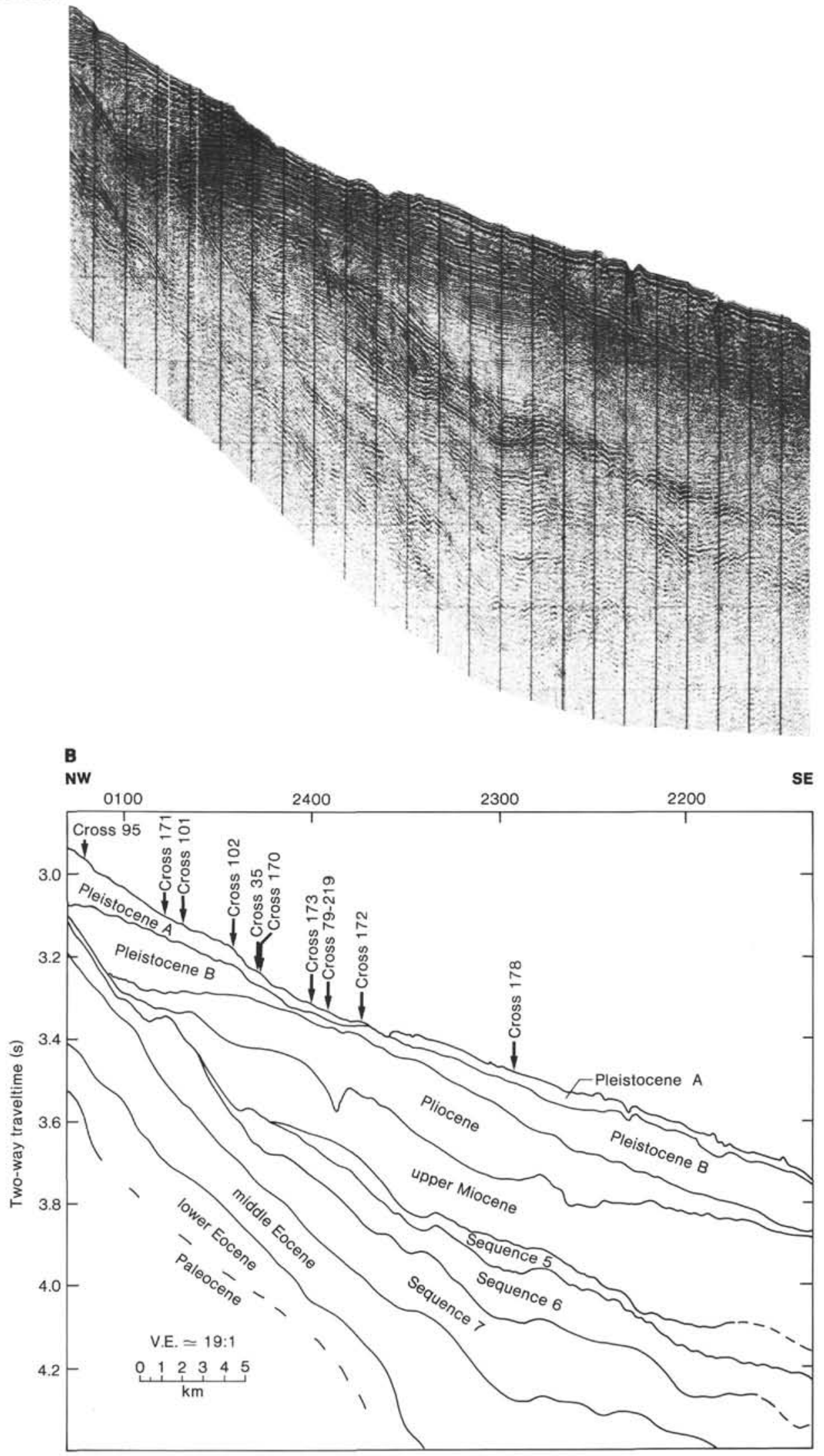

Figure 18. A. Uninterpreted segment of single-channel seismic Line 183. B. Interpretation of single-channel seismic Line 183. This dip section shows stratigraphic relationships downdip from Site 612 and SW of the other three DSDP drill sites. Note the onlapping of post-middle Eocene sequences and the irregular erosional contacts. Pleistocene Unit A is breached near the center of the figure, where Unit B also is thinnest. 
The middle Eocene surface is the most severely channelled in this region; some of the largest channels are $240 \mathrm{~m}$ deep and $2.5 \mathrm{~km}$ across and cut through nearly the entire middle Eocene section (e.g., Line 171; Figs. 12A, B). The upper reflections of all sequences are clearly truncated at many locations along the seismic lines, and their basal reflections often onlap underlying reflections. These angular relationships attest to the prevalence of unconformable contacts. The common occurrence of chaotic and distorted seismic facies combined with the documented borehole lithologies shows that downslope mass movement of sediments (debris flows, turbidity currents, and slumps) was the principal agent of deposition and erosion in this part of the upper rise.

The dip lines corroborate the stratigraphic and facies interpretations of the strike lines, and illustrate how false an impression of the regional geology a single dip line can give. For example, dip Lines 176 (Appendix Figs. 5A, B) and 183 (Figs. 18A, B) show a relatively thick Sequence 7 crossing both profiles, but $3-4 \mathrm{~km}$ to either side along strike Line 171 (Figs. 12A, B), Sequence 7 is very thin or entirely missing. Lines 176 and 183 fortuitously cross major channels on the middle Eocene surface, where Sequence 7 is thickest.

\section{Multichannel Seismic Grid}

In order to expand our interpretation to cover the entire New Jersey margin, we analyzed an intersecting network of 11 multichannel seismic reflection profiles running parallel to the dip direction, and 4 subparallel to the strike direction (Fig. 1; Figs. 19-21 [back pocket]). Of these, 3 dip lines, 25, 79-221, and 79-214) and 2 strike lines ( 35 and 79-201) were described in some detail by Poag (1985b). We refine his analyses and include a more complete set of profiles (Figs. 19, 20 [back pocket]).

Depth sections across this margin (Lines 25, 2, 6, 79221, and 79-214) and seismic facies analyses show that the shelfbreak during the Late Cretaceous-early Eocene interval was near where strike Line 34 crosses dip Lines 79-221 to 79-218 (Fig. 1; Figs. 19, 20 [back pocket]; see Schlee, Dillon and Grow, 1979; Poag and Low, this volume), and to the northeast, the shelfbreak was even farther seaward where strike Lines 35 or $79-205$ cross dip Lines 79-217 to 79-214 (Fig. 1; Figs. 19, 20 [back pocket]).

The ancient continental slope, during the Late Cretaceous to early Eocene, lay beneath drill Sites 604, 605, and 613 (Fig. 22). The Late Cretaceous through lower Eocene sequences tend to thicken or mound in the vicinity of the ancient slope-rise transition, apparently in response to the decreased seaward gradient. As shown clearly along Line 35, however, (Fig. 21 [back pocket]), these sequences also underwent severe downslope channelling along the ancient slope and upper rise, and they are thickest where they fill channels or where their upper surfaces are not channelled. These sequences thin across interchannel ridges or beneath deep channels. The Paleocene sequence is the only one of these early Cenozoic units that does not extend up the slope to the outer part of the ancient shelf (at least not in thicknesses detect- able on the multichannel profiles [5-10 $\mathrm{m}$ or more]). The Campanian, Maestrichtian, and Paleocene sequences thin seaward of the vicinity of strike Line 35 (Figs. 19, 20 [back pocket]), but the lower and, especially, the middle Eocene sequences thicken to the southeast.

Following early Eocene deposition, a significant change in sedimentary regime took place, as expressed by the onlapping pattern of subsequently deposited rise sequences and a dramatic landward shift of the shelfbreak (Figs. 19, 20 [back pocket]; Fig. 22; see also Poag and Low, this volume, and Poag, this volume). Some of these younger sequences of the upper rise may have originally extended without interruption all the way across the present outcrop of middle Eocene carbonates (Figs. 19, 20 [back pocket]) to their equivalents on the present continental slope. We know, however, from the evidence of middle Eocene clasts and microfossils incorporated among the late Miocene and younger strata at Sites 604, 605, and 613 , that the middle Eocene surface must have been extensively exposed along the lower slope for at least the last 6-10 my. Some of the younger units, especially the undrilled Sequences 4-7, also have more limited distributions along strike than the older units. For example, Sequences 5-7 are not present to the northeast of Line 79-216, and Sequence 4 is not present southwest of Line 79-217 (see Appendix ).

The strike lines show that the downslope channelling, characteristic of the Late Cretaceous and Paleogene, continued to be an important agent of erosion during the Neogene and Quaternary over the entire upper-rise region of the study area. Channelling was most severe throughout the Cenozoic in the vicinity of Line 35 (Fig. 21, [back pocket]) and diminished updip (Line 34) and downdip (Line 79-201), except during the Pleistocene. The channels also diminished along Line 35 (in frequency and depth of excavation), following erosion of the middle Eocene surface, and remained less active until the advent of the Pleistocene, when the extant submarine canyons developed. In considering the implications of this study for the general stratigraphic and depositional history of the entire margin, however, one must be careful not to extrapolate too many of the detailed relationships shown in this limited area. For example, (1) some features, such as the distinctive broad channels filled by Campanian strata along Line 79-201 (see below), are restricted geographically; in this case, appearing only in the northeast segment of the study area; (2) the distribution of some larger features, such as the four undrilled sequences, is also geographically limited, as we discuss more thoroughly in the next section.

\section{ISOPACH MAPS AND THEIR IMPLICATIONS}

In order to understand more fully the depositional and erosional patterns displayed on the single-channel and multichannel seismic grids, we constructed isopach maps for each of the 12 defined sequences (Appendix Figs. 6-17). The thickness of each sequence (in 2-way traveltime) was measured along the multichannel lines, and the resultant maps were checked against the singlechannel grid (between Lines 79-219 and 79-218) in order 


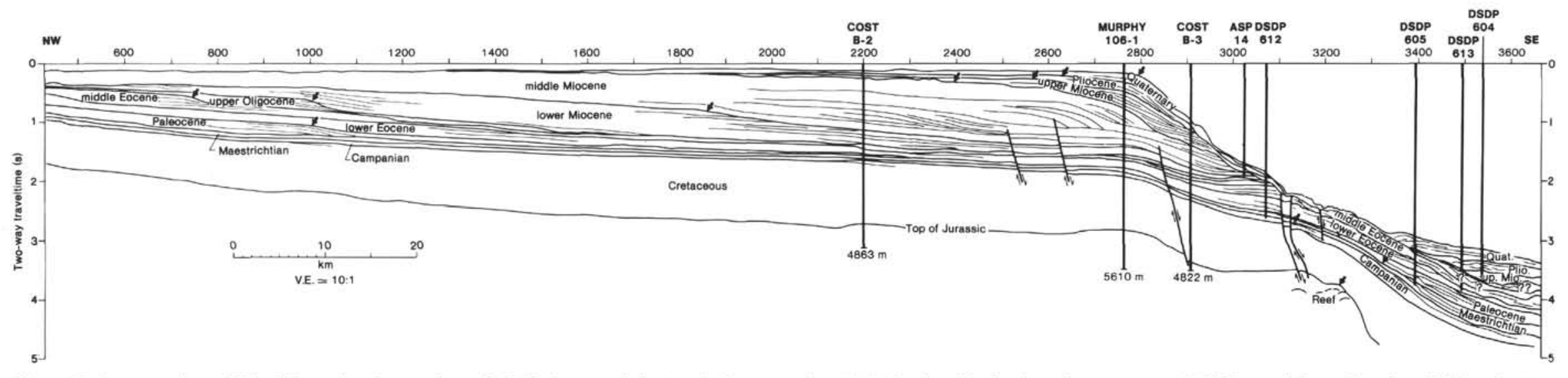

Figure 22. Interpretation of Line 25 crossing the continental shelf, slope, and rise (vertical exaggeration 10:1) showing distribution of sequences and shifting positions of ancient shelfbreaks (arrows). Note how shelfbreak shifts dramatically shoreward during Paleogene and then progressively progrades seaward to present position. Also note the three subsequences of the middle Miocene delta complex. See Poag and Low (this volume) for further discussion. 
to avoid erroneous extrapolations in the vicinity of the boreholes. We discuss the sequences from oldest to youngest in order to trace the historical development of the margin.

\section{Sequence 12-Campanian}

\section{Distribution and Thickness Relationships}

The Campanian sequence is present throughout the entire study area (Appendix Fig. 6). It forms a broad slope-front-fill that is thickest in the center and to the northeast and thins both up- and downdip. Maximum measured thickness is $0.48 \mathrm{~s}$ (ca. $550 \mathrm{~m}$ ).

Superimposed on the generally lenticular geometry of this sequence is a series of downslope-trending, thickened pods, which alternate across the slope with thinner intervening regions, producing a "ribbed" downslope fabric. Along strike Lines 34 and 35 (Fig. 21 [back pocket]), the "ribbing" is produced both by erosion of deep channels in the upper surface of the sequence (thinning), and by filling channels cut into the underlying surface (thickening). Along the most seaward strike line (79-201), however, the principal component of ribbing is the filling of broad channels (as wide as $17 \mathrm{~km}$ ) on the underlying surface (Fig. 23).

\section{Seismic Facies Characteristics}

On the multichannel seismic lines the Campanian sequence comprises zones of moderately-high-amplitude, parallel-to-subparallel, continuous reflections, suggesting relatively uniform deposition. These zones are interrupted at irregular intervals by chaotic or poorly defined reflections, indicating downslope mass movement. The latter are particularly prevalent along Line 35 and seaward (Figs. 19, 20 [back pocket]).

\section{Sequence 11-Maestrichtian}

\section{Distribution and Thickness Relationships}

The general distribution and geometry of the Maestrichtian sequence is similar to that of the Campanian sequence (Appendix Fig. 7). It forms a broad lens of slope-front-fill upon which is superimposed a downslope ribbed fabric, caused chiefly by filling of channels on the underlying Campanian surface (Figs. 19-21 [back pocket]), and by subsequent channelling of the Maestrichtian surface. The Maestrichtian sequence is markedly thinner, however, than the Campanian, and reaches a thickness as much as $0.4 \mathrm{~s}$ in only one narrow rounded deposit along Line 2 (Appendix Fig. 7).

Another mounded deposit, seen in strike section along Line 79-201 (between 79-220 and 79-219; Fig. 21 [back pocket]), has the characteristics of a small fan lobe (Fig. 24).

\section{Seismic Facies Characteristics}

Along multichannel seismic lines, the Maestrichtian sequence displays chiefly onlap-fill and chaotic-fill facies, characteristic of the downslope mass transport of sediment.

\section{Sequence 10-Paleocene}

\section{Distribution and Thickness Relationships}

The distribution of the Paleocene sequence is much more limited in the study area than the two Upper Cretaceous sequences. Paleocene strata are missing on the continental slope (Appendix Fig. 8) and also (having been eroded) along much of the downdip strike Line 79-201 (Fig. 21 [back pocket]). Its general geometry is lenticular (slope-front-fill), like the Upper Cretaceous sequences, but it is considerably thinner (maximum thickness ca. $0.28 \mathrm{~s} \simeq 325 \mathrm{~m}$ ). The downslope ribbed fabric again is prominent, caused by filling of channels on the Maestrichtian surface (Figs. 19-21 [back pocket]) and subsequent channelling of the Paleocene surface. Channelling of the Paleocene surface is especially prominent along Line 35 (Fig. 21 [back pocket]). The Paleocene sequence continues as a thin sheetlike deposit along Line 25 downdip from Line 79-201, outside the study area.

\section{Seismic Facies Characteristics}

Chaotic-fill facies are commonly associated with the downslope channels in the Paleocene sequence. Nonchannelled regions contain primarily hummocky and subparallel reflections (Figs. 19-21 [back pocket]).

\section{Sequence 9-Lower Eocene}

\section{Distribution and Thickness Relationships}

The lower Eocene sequence is present over the entire study area except for a broad longslope erosional swath between Lines 35 and 79-201 and in a few additional smaller erosional patches in the vicinity of Line 35 (Appendix Fig. 9). The lower Eocene sequence is generally thickest $(0.2-0.25 \mathrm{~s})$ along Line 34 and to the northeast along Line 2, but reaches as much as $0.35 \mathrm{~s}$ (ca. $325 \mathrm{~m}$ ) in a single pod along Line 79-219 (Figs. 20, 21 [back pocket]). It has been thinned by erosion along a broad, central, longslope swath, but thickens again downdip along Line 79-201 and continues to thicken southeastward outside the study area, on Line 25 . The longslope pattern of erosion suggests that bottom currents were an effective erosive agent in this region during the early Eocene.

Superimposed on this longslope pattern is the familiar downslope ribbed fabric produced along and updip from Line 35, chiefly by severe channelling on the upper surface of Sequence 9. In fact, at several spots along Line 35, Sequence 9 has been entirely removed (Figs. 19-21 [back pocket]). Along the downdip strike line (79-201; Fig. 21 [back pocket]), however, channelling on the upper surface is not significant, and most of the thickened pods represent filling of underlying channels. Arched reflections in two mounded sections in the northeast corner of the study area may, however, represent fan lobes (Fig. 25).

\section{Seismic Facies Characteristics}

Onlap-fill and chaotic-fill facies dominate the downdip areas of early Eocene deposition. Updip, however 
sw

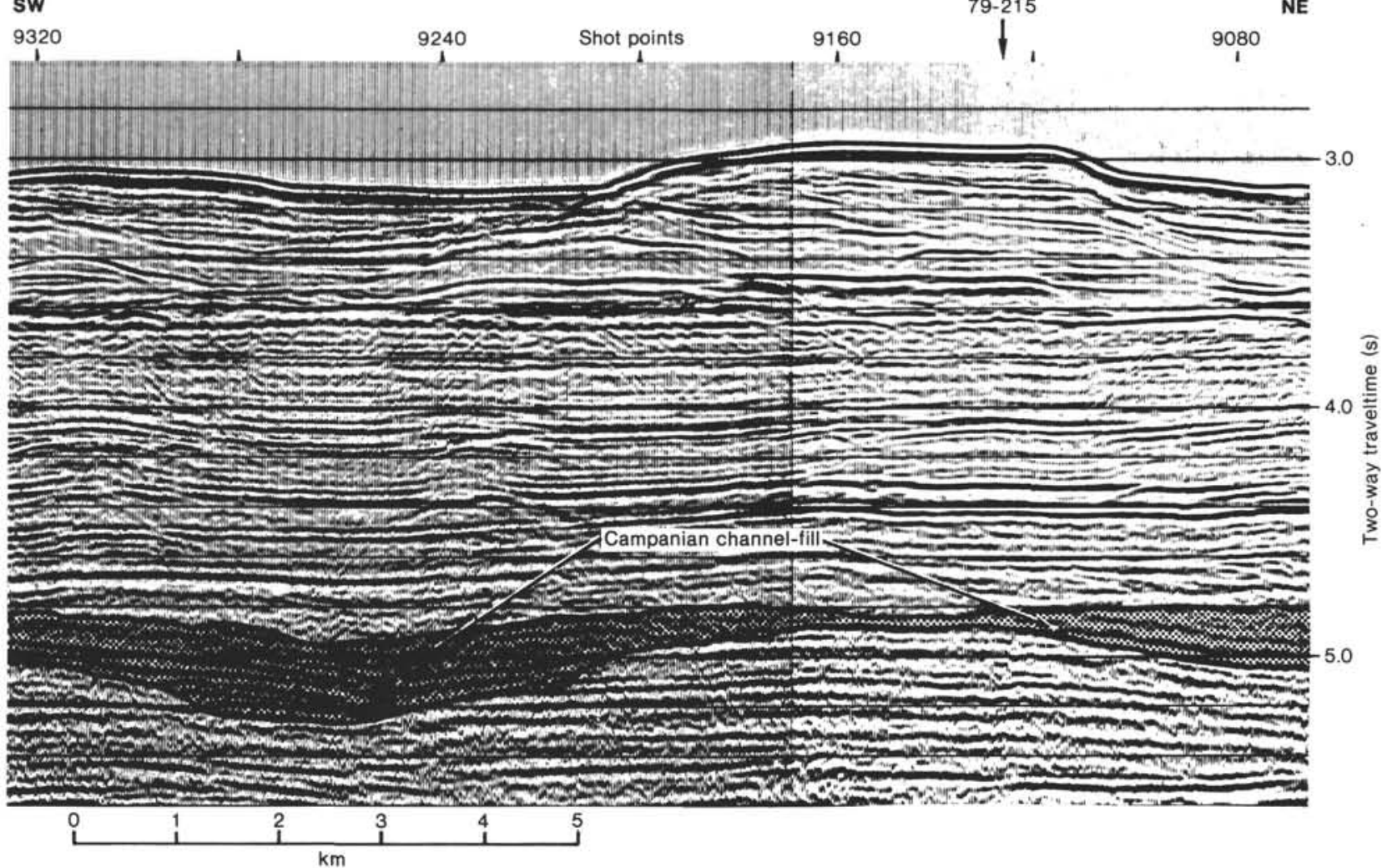

$\mathrm{km}$

Figure 23. Channels filled with Campanian strata (Sequence 12) along the northern end of multichannel seismic Line 79-201.

$\begin{array}{lccc}\text { SW } & \text { Cross } & \text { Shot points } & 11200 \\ 11360 & 11280 & 1 & 119\end{array}$

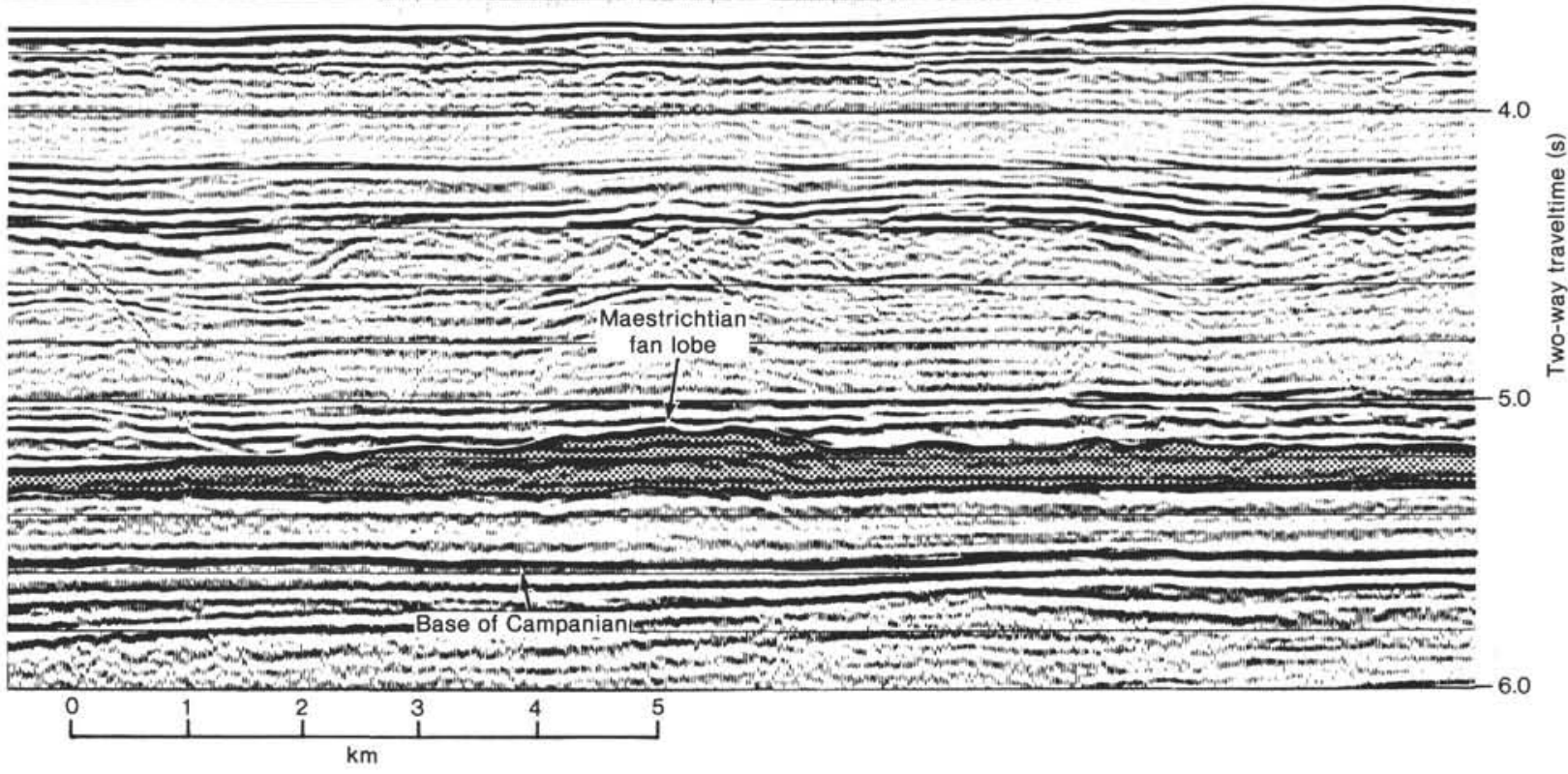

Figure 24. A fan lobe of Maestrichtian strata (Sequence 11) on multichannel seismic Line 79-201. 


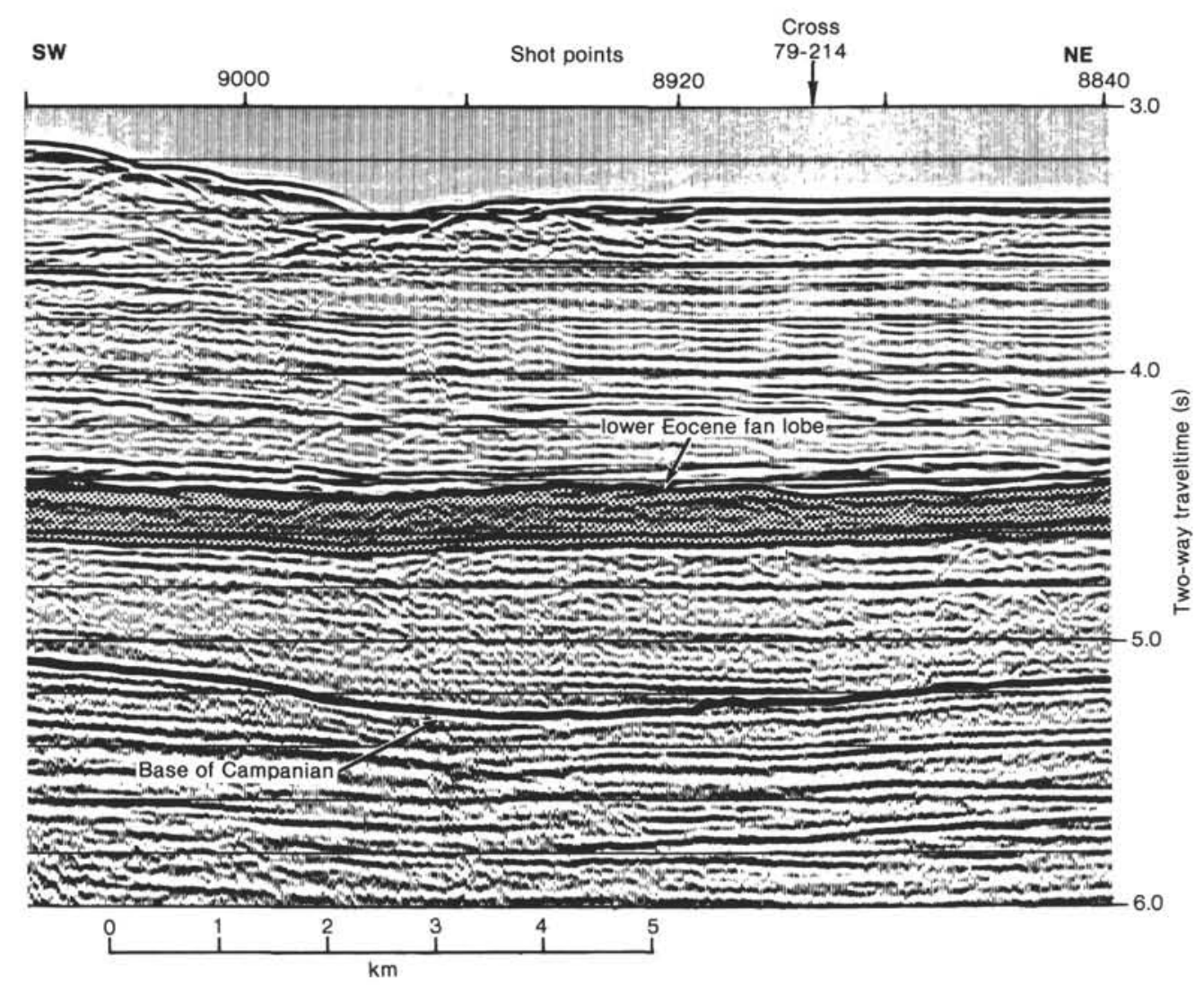

Figure 25. Fan lobes of lower Eocene strata (Sequence 9) on multichannel seismic Line 79-201.

(e.g., Line 34; Fig. 21 [back pocket]), broad reflectionfree zones on multichannel lines indicate undisturbed homogeneous deposits. The single-channel lines (e.g., 105; Figs. 13A, B) show particularly well the contrasting updip (ancient shelf) and downdip (ancient slope) seismic facies. Updip the lower Eocene sequence is characterized by high-amplitude, subparallel, subcontinuous reflections in the upper two-thirds of the section, but it becomes essentially reflection-free in the basal third. Downdip, the upper third contains very-high-amplitude reflections associated with the porcellanite zone, but reflections are chaotic and poorly defined in the lower two thirds.

\section{Sequence 8-Middle Eocene}

\section{Distribution and Thickness Relationships}

The middle Eocene sequence is continuous across the study area, except in a series of longslope erosional patches between Lines 35 and 79-201 and a few other scattered patches to the northwest of Line 35 (Appendix Fig. 10). It is generally thin (less than $0.20 \mathrm{~s} \sim 180 \mathrm{~m}$ ) updip from the longslope erosional swath, but thickens dramatically downdip across Line 79-201 and south of Line 2 (Figs. 19-21 [back pocket]). Maximum thickness measured was ca. $0.45 \mathrm{~s} \mathrm{(ca.} 420 \mathrm{~m}$ ) along the downdip end of Line 79221 . The sequence continues to gradually thicken southeastward along Line 25 beyond the study area. The longslope erosional swath suggests continued effectiveness of bottom currents during the middle Eocene to early late Eocene.

Superimposed on the general pattern of seaward thickening basin fill is a pronounced fabric of downslope ribbing. Along Line 35 the elongate thickened pods are caused by the filling of channels cut into the underlying lower Eocene surface (Fig. 21 [back pocket]), whereas along Line 34 , thinning is significant where channels were cut into the upper surface of the middle Eocene sequence.

Middle Eocene reflections are truncated along the updip margin of the longslope erosional swath around Line 79-215 (Fig. 26), suggesting that the sequence originally extended farther downdip (Figs. 19, 20 [back pocket]). Along Line 79-220, however, the middle Eocene sequence pinches out both up- and downdip around a mound of lower Eocene strata, which suggests that middle Eocene sediments never covered the mound.

\section{Seismic Facies Characteristics}

Onlap-fill, slope-front-fill, and chaotic-fill are prominent middle Eocene seismic facies on multichannel lines beneath the upper rise wedge, but broad reflection-free intervals updip from Line 34 (Figs. 19-21 [back pocket]) and downdip from Line 79-201 suggest more uniform, undisturbed depositional styles.

Single-channel profiles yield a different picture of seismic facies. Updip from Line 34, the middle Eocene sequence contains many closely spaced, parallel, continu- 


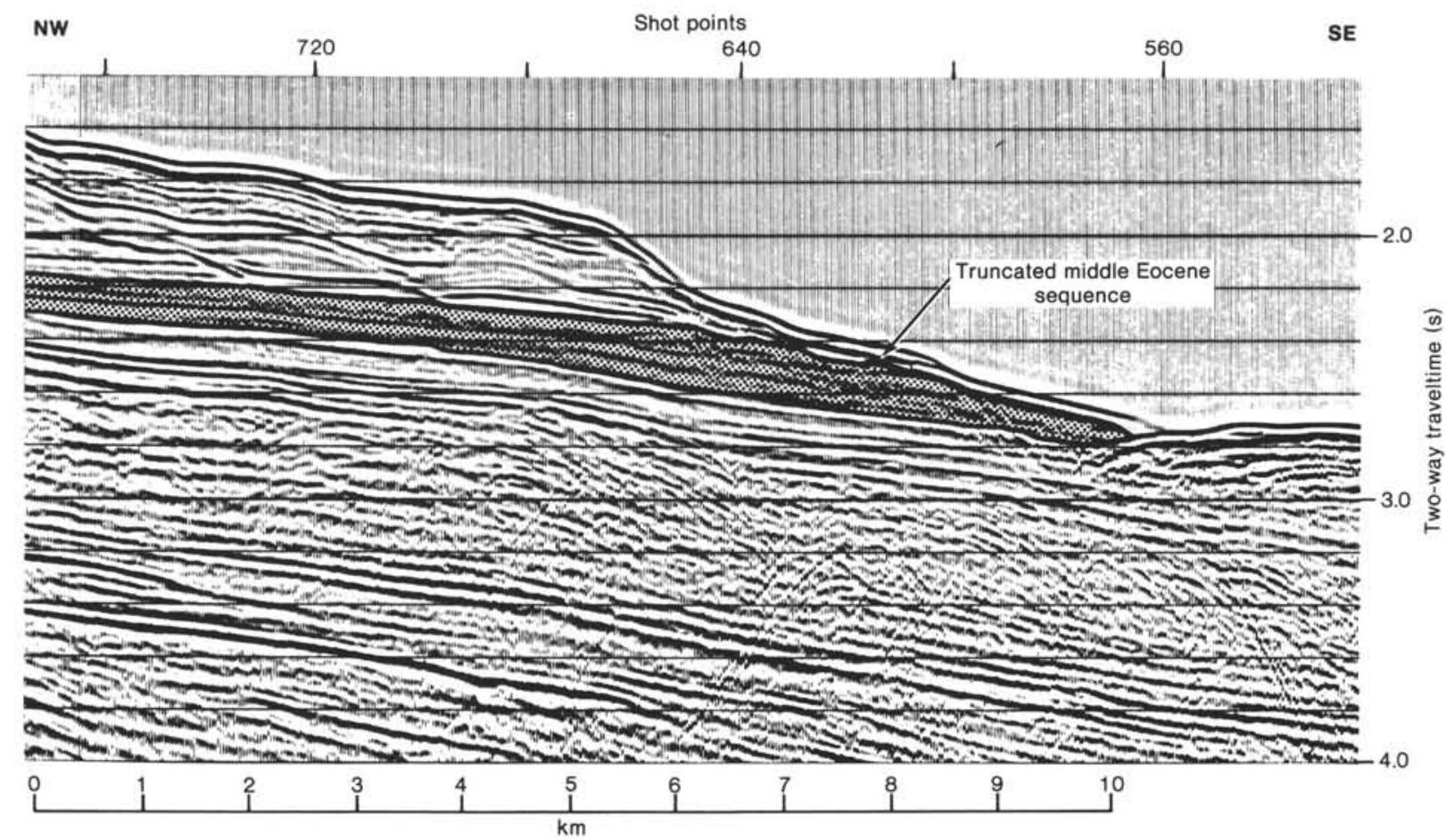

Figure 26. Truncated reflections in middle Eocene strata (Sequence 8) along the updip margin of an erosional swath along multichannel seismic Line 79-215.

ous, high-amplitude reflections. These suggest uniform depositional conditions, as documented at Site 612 (Figs. 4-6). Downdip from Line 35, however, the single-channel dip lines show a complex of chaotic or sinuous reflections, indicative of downslope mass movement (e.g., Line 105; Figs. 13A, B).

\section{Sequence 7-Undrilled}

The strata of Sequence 7, tentatively assigned by Poag (1985b) to the upper Eocene, have not been sampled by any boreholes in the upper rise segment of the study area. However, the sequence is quite distinct, as discussed above, and by Poag (1985b). It is present in the central and southwest parts of the study area, and is separated from well documented upper Eocene strata of the shelf and slope, by a wide erosional swath, in which middle Eocene chalks and limestones crop out on the seafloor (Appendix Fig. 11). The facing margins of the updip and downdip sedimentary prisms have been deeply scalloped by post-Eocene erosion (Appendix Fig. 11); this is particularly true of the updip prism, whose exposed edge was deeply channelled during the Pleistocene by sediments moving downslope through large submarine canyons.

The thickness patterns of the updip prism also reflect significant downslope channelling of its upper surface, resulting in the same downslope ribbed fabric seen in older sequences (Appendix Figs. 1-10). The updip upper Eocene prism appears to pinch out to the northwest, along the outer part of the present continental shelf, before it reaches Line 79-204 (Fig. 1), although a very thin layer, not detectable by the multichannel seismic system, may extend landward of this apparent pinch-out.
Within the downdip prism (on the upper rise), the downslope ribbed fabric still pervades, but its constituents are more complex. Along Line 35, the thicker pods are primarily channel fill (Fig. 21 [back pocket]). The sequence thickens regionally along the southwest end of Line 79-201, but here also, thick pods of channel fill are prominent (Fig. 21 [back pocket]). This corner of the study area contains the maximum thickness of Sequence 7 (as much as $0.36 \mathrm{~s} \simeq 250 \mathrm{~m}$ ).

A small fan lobe is present northeast of the intersection of Line 79-201 with Line 79-218, bordered on each side by erosional surfaces (Fig. 27). Truncated reflections along the northeast margin of the downdip prism of Sequence 7 indicate that the prism originally extended farther to the northeast (Fig. 28). It can be traced as a rather uniformly thick tabular body along Line 25 southeast of the study area.

\section{Seismic Facies Characteristics}

The generally lenticular geometry of Sequence 7 is interpreted as slope-front-fill that pinches out updip on the eroded middle Eocene surface. Onlap-fill and chaotic-fill facies are common on the multichannel lines in the upper rise segment (Figs. 19, 20 [back pocket]). On the upper slope, this sequence is expressed as a few moderate- to high-amplitude parallel, continuous reflections.

On the single-channel lines, the updip prism contains numerous parallel, continuous, moderately-high-amplitude reflections, similar to those of the middle Eocene sequence (Figs. 4-6). On the slope and rise, single-channel dip lines show similar reflections, which are more sinuous and often contorted or chaotic in channels near 


\begin{tabular}{lllll} 
SW & \multicolumn{3}{c}{ Shot points } & NE \\
1 & 10640 & 10560 & 10480 & 1 \\
\hline
\end{tabular}

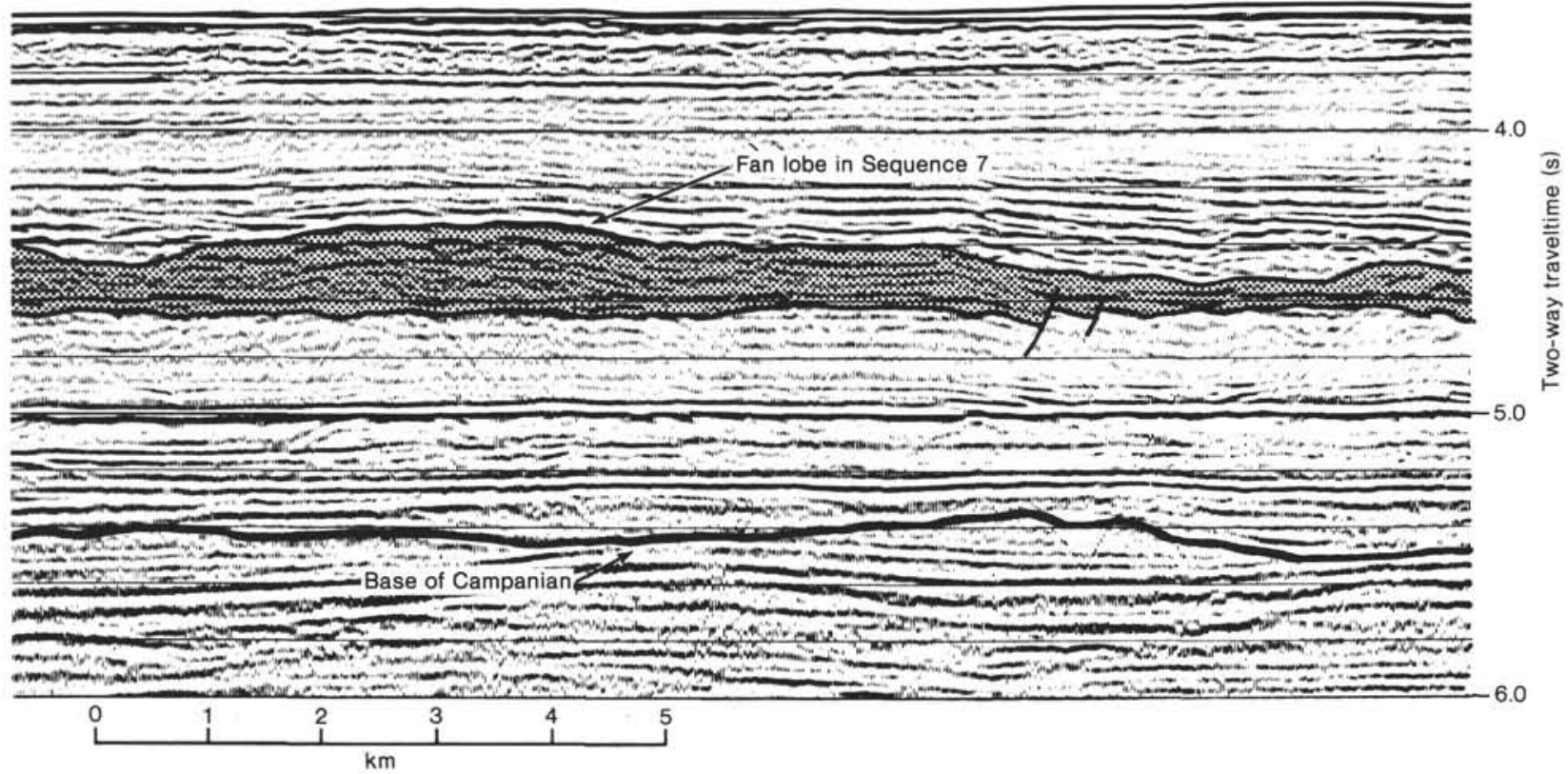

Figure 27. Fan lobe of Sequence 7 strata near the intersection of multichannel seismic Line 79-201 and 79-218.

the base of the sequence (Figs. 13A, B). Strike lines generally show parallel, subcontinuous, high-amplitude reflections in the upper part of the channel-fill, but contorted and chaotic reflections deeper in the channels (Figs. 12A, B).

\section{Sequence 6-Undrilled}

\section{Distribution and Thickness Relationships}

Sequence 6 has not been sampled on the upper rise. Poag (1985b) tentatively assigned it to the lower Oligocene, presuming that it included earliest late Oligocene deposits of the major low-stand of sea level (Vail et al., 1977). The upper-rise prism of Sequence 6 is separated from a thin upper-slope prism of upper Oligocene strata, by the outcropping middle Eocene carbonates. This updip prism has been sparsely sampled (Site 612 and ASP 15) and appears from single-channel profiles to be confined to a narrow band along the upper slope. It can be traced along strike, for example, on Line 89 (Figs. 7A, B).

On the upper rise, Sequence 6 is restricted, like Sequence 7, to the central and southwestern parts of the study area (Appendix Fig. 12). Truncated reflections on its northeastern margin suggest, however, that the original deposit extended over a wider region.

Sequence 6 is relatively thin in the study area, rarely reaching a thickness of $0.2 \mathrm{~s}$ (ca. $140 \mathrm{~m})$. It is much thicker $(0.55 \mathrm{~s})$ to the southwest, however, along Line 79-201, beyond the limits of this study. Downdip along
Line 25 its thickness is quite variable (Fig. 21 [back pocket]), and it can be traced well beyond the study area. The downslope ribbed fabric is more strongly developed in this sequence than in any other studied (Appendix Fig. 12). This is due both to filling of channels in the underlying sequence (Figs. 19-21 [back pocket]) and subsequent extensive channelling of its upper surface. One prominent fan lobe accounts for the broad thickening near the northeast margin of its distribution (Fig. 29).

\section{Seismic Facies Characteristics}

On multichannel lines the reflections within Sequence 6 are often contorted and chaotic, suggesting extensive downslope mass displacement of sediment (Figs. 19-21 [back pocket]). Single-channel profiles show high-amplitude, subparallel, subcontinuous reflections near the top and base of the sequence (Figs. 15A, B). Some of the thickest lobes are nearly reflector-free, but most channels are filled by chaotic reflections.

\section{Sequence 5-Undrilled}

\section{Distribution and Thickness Relationships}

The distribution pattern of Sequence 5 (tentatively assigned by Poag, [1985b] to the upper Oligocene) is similar to that of Sequence 6 (Appendix Fig. 13). It is composed of a downdip prism on the upper rise, which has not been drilled. A possibly equivalent upper Oligocene prism is present on the shelf and upper slope, having been sampled at the COST B-3 well (Figs. 9A, B). 

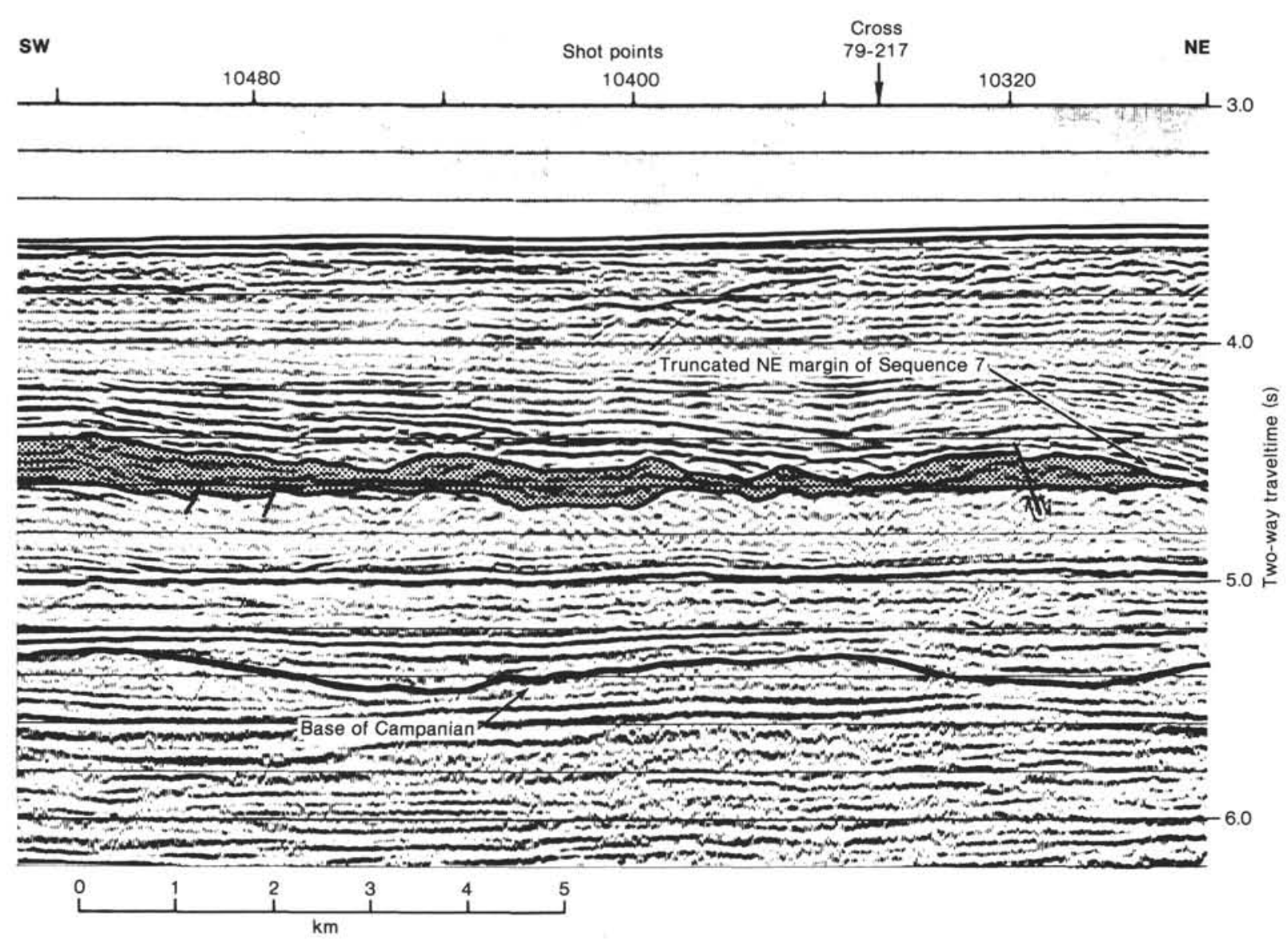

Figure 28. Truncated reflections along the eroded northeast margin of Sequence 7.

The two prisms are separated by a broad expanse of erosion (and nondeposition?), which includes the middle Eocene outcrop belt.

The downdip prism is restricted to the central and southwest parts of the study area, and is the thinnest unit studied, generally being $0.15-0.17 \mathrm{~s}(\simeq 100-120 \mathrm{~m})$ thick or less (Appendix Fig. 13). It thickens gradually downdip, but has been completely eroded away in several small patches. Along Line 25, Sequence 5 thins and pinches out southeast of the study area at shot point 4460. The downslope ribbed fabric is prominent; thickest lobes (Lines 79-220 and 6) are channel fill (Figs. 19, 20 [back pocket]).

\section{Seismic Facies Characteristics}

Sequence 5 displays slope-front and onlap-fill facies on multichannel lines, becoming somewhat chaotic in channel fills (Figs. 19-21 [back pocket]). On the singlechannel lines, the thinner areas have moderately highamplitude, subcontinuous, subparallel reflections, but the channel fill is generally chaotic (Figs. 18A, B).

\section{Sequence 4-Undrilled}

\section{Distribution and Thickness Relationships}

The distribution pattern of Sequence 4 (tentatively assigned by Poag [1985b] to the middle Miocene) differs from all other sequences in that the unsampled downdip prism is restricted to the northeast half of the study area (Appendix Fig. 14). The tentatively equivalent updip prism extends across the entire length of the study area, and has been sampled at several boreholes; it is separated from the downdip prism by an erosional swath in which the middle Eocene sequence forms a seafloor exposure. The scalloped margin of the updip prism reflects the positions of the extant submarine canyons.

The upper slope prism is part of a huge middle Miocene delta complex (Poag, 1985a) whose main depocenter is in the vicinity of Lines 6 and 79-221 (Figs. 19, 20 [back pocket]), suggesting that its source may have been a proto-Delaware River. In this depocenter, the sequence thickens to as much as $1.2 \mathrm{~s}$ (ca. $850 \mathrm{~m}$ ) and its eroded seaward face forms a relatively steep escarpment (Fig. 30).

The upper-rise prism of Sequence 4 thickens seaward and to the northeast, reaching a maximum of ca. $0.36 \mathrm{~s}$ $(\simeq 260 \mathrm{~m})$ in one fan lobe along Line 2 . The sequence continues to thicken northeastward outside the study area along Line 79-201 (reaches $0.45 \mathrm{~s}$ thickness; $\simeq 325 \mathrm{~m}$ ). Reflections are truncated along the southwest margin of the upper rise prism (Line 79-201; Fig. 21 [back pocket]), suggesting that it originally extended farther in this direction. It is present on Line 25 outside the study area, seaward of shot point 5280. Equivalent middle Miocene strata have been sampled farther out on the lower rise at Site 105 (Fig. 1; Hollister, Ewing et al., 1977) and 603 (300 m thick at Site 603; van Hinte, Wise, et al., in press). 


\begin{tabular}{|c|c|c|c|c|c|c|c|c|}
\hline sw & $\stackrel{10240}{1}$ & & 10160 & Shot points & $\stackrel{10080}{1}$ & $\stackrel{\substack{\text { Cross } \\
79-216}}{\downarrow}$ & 10000 & $\begin{array}{l}\text { NE } \\
9940 \\
\end{array}$ \\
\hline & $y=$ & & & & & & & \\
\hline
\end{tabular}

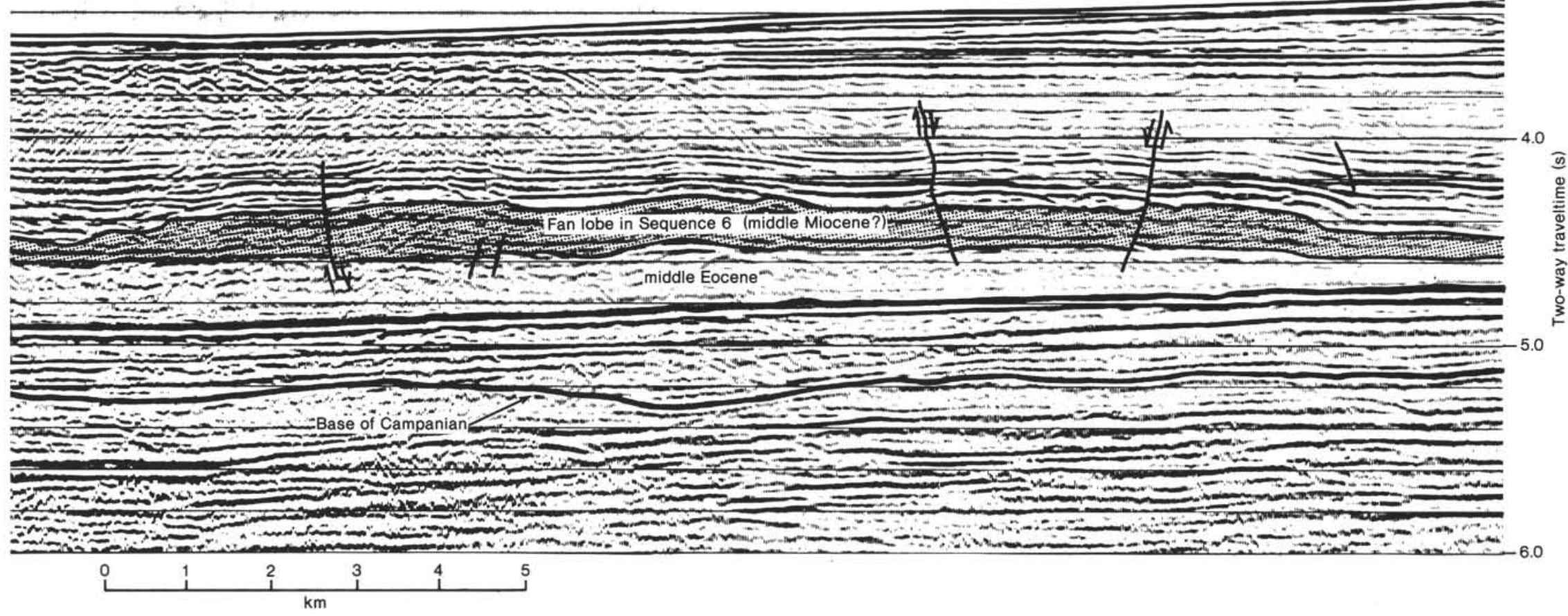

Figure 29. Fan lobe of Sequence 6 strata along the northeast extension of multichannel seismic Line 79-201. Note also normal faults that originate in middle Eocene section and note the broad Campanian channels. 


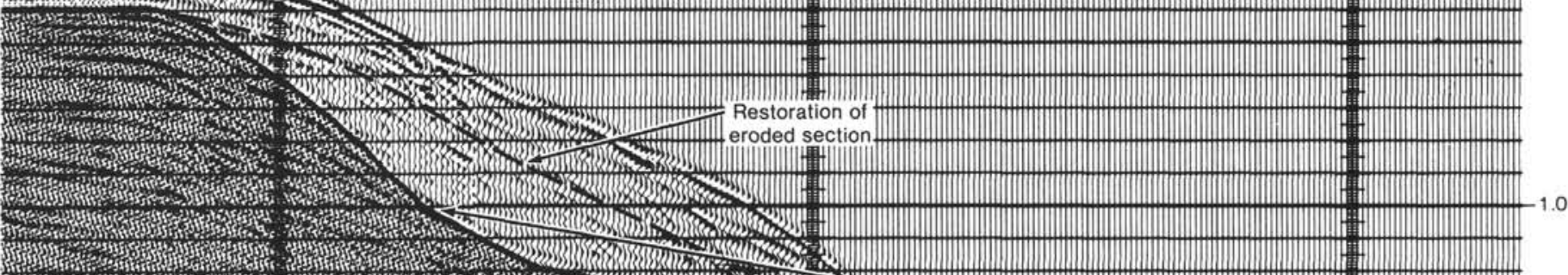

Figure 30. Seismic expression of eroded margin of the middle Miocene delta on Line 6 near its depocenter. 
A downslope, ribbed fabric is produced by channel-fill, fan lobes, and channelling on its upper surface along Line 79-201 (Fig. 21 [back pocket]).

\section{Seismic Facies Characteristics}

Along the multichannel lines, Sequence 4 is most commonly expressed as onlap fill and chaotic fill. It is not present within the single-channel seismic grid.

\section{Sequence 3-Upper Miocene}

\section{Distribution and Thickness Relationships}

The upper Miocene sequence has been sampled, although sparsely, on both its upper slope and upper rise prisms (which are separated by a wide erosional swath; Appendix Fig. 15). Its distribution along the upper rise is quite irregular because of its presence as channel fill on a rough underlying topography and because of severe erosion of its upper surface (Figs. 4-9). The thickness of this sequence is poorly documented in the upper slope prism, but it may reach $0.4-0.5 \mathrm{~s}(\mathrm{ca} .350 \mathrm{~m})$ along Line 79-215 (Figs. 19, 20 [back pocket]).

On the upper rise, Sequence 3 typically forms a long thin tongue (on dip lines) that onlaps older units (Fig. 16). It thickens rather abruptly seaward along Line 79-201, reaching a maximum of $0.44 \mathrm{~s}(\mathrm{ca} .320 \mathrm{~m})$ in channel fill in the northeast corner of the study area (Figs. 19-21 [back pocket]).

A downslope ribbed fabric is developed principally as the result of filling deep channels in the underlying surfaces, but channelling on its upper surface is also conspicuous along some lines (e.g., Lines 25, 101, 171, 176; Fig. 12; Appendix Figs. 1, 5). Seaward of the study area it thickens to as much as $0.7 \mathrm{~s} \mathrm{(ca.} 500 \mathrm{~m}$ ) along Line 25 .

\section{Seismic Facies Characteristics}

Sequence 3 is expressed as chaotic fill in most of the channels (Figs. 19-21 [back pocket]), but elsewhere is chiefly onlap fill and slope-front fill. Downdip from the study area, on Line 25 , reflector-free zones indicate more uniform, less chaotic depositional conditions.

\section{Sequence 2-Pliocene}

\section{Distribution and Thickness Relationships}

The Pliocene sequence is separated into two parts; an updip prism on the slope and outer shelf, and a downdip prism on the upper rise (Appendix Fig. 16). The two prisms are separated by a broad erosional swath that exposes middle Eocene strata. The updip prism has been well-documented only at Site 612 , so its distribution is principally an extrapolation from there. A broad lobe of Pliocene sediment extends downdip to the northeast, narrowing the erosional swath along Lines 2 and 79-215 (Appendix Fig. 16). This geometry suggests deltaic progradation in this area.

On the downdip prism, Sequence 2 was documented at Sites 604 and 613, and can be confidently extrapolated along the closely spaced single-channel and multichannel seismic grids. The downdip prism thickens gradu- ally seaward, but is particularly thick in elongate channel-fill deposits and in a broad fan lobe along Line 79201 (Fig. 31; maximum thickness is $0.31 \mathrm{~s}$ in the fan lobe; $\simeq 225 \mathrm{~m}$ ).

The familiar downslope ribbed fabric is present in this sequence, caused by channel fill along its base (Figs. 15A, B) and erosional excavation of its upper surface (Appendix Figs. 1, 2). Superimposed on the downslope fabric is a longslope fabric, seen in the northeast and southwest extremities of the study area (Appendix Fig. 16). This suggests that bottom currents were effective depositional and erosional agents during the Pliocene.

\section{Seismic Facies Characteristics}

On multichannel seismic lines, onlap-fill and chaoticfill facies are the most common expression of Sequence 2 on the upper rise prism (Figs. 19-21 [back pocket]). On the upper slope, if forms a lenticular slope-front fill. On single-channel lines, Sequence 2 is typically a series of parallel, continuous, high-amplitude reflections, which are contorted or chaotic where it fills channels in the underlying sequences (Appendix Figs. 1, 2).

\section{Sequence 1-Pleistocene}

The Pleistocene sequence is well documented by drilling and other types of sampling both on the updip and downdip prisms (Appendix Fig. 17). The two prisms are separated by an erosional swath that exposes middle Eocene strata at the seafloor. The middle Eocene exposure is now much narrower than it was in the past, having been overlapped extensively by Pleistocene deposits (e.g., see Lines 79-217 and 79-218; Figs. 19, 20 [back pocket]). The deeply lobed lower margin of the updip prisms is a product of deep entrenchment by existing submarine canyons. To the northeast, two lobes of the updip prism extend nearly or completely across the Eocene erosion surface, suggesting continuation of the deltaic progradation begun during the Pliocene. These deltaic lobes are faced on the upper-rise prism by a broad, unusually thick Pleistocene deposit $(0.7 \mathrm{sec} ; \simeq 500 \mathrm{~m})$ that resembles a large fan lobe (Appendix Fig. 17; both Pleistocene Units A and B thicken here).

A downslope ribbed fabric is strongly developed in the Pleistocene sequence. The thickness variations of the total Pleistocene sequence are due to differential erosion and deposition on the top of Pleistocene Unit A (its base is relatively smooth; Figs. 12A, B) and the filling of downslope channels by Pleistocene Unit B (Figs. 12A, B). Outside the study area, along Line 25, Unit A thickens only slightly downdip, but Unit B becomes significantly thicker. A weak component of longslope erosion is reflected in a thin central trough between Lines 79-220 and 79-217 (Appendix Fig. 17), but the downslope fabric dominates.

\section{Seismic Reflection Characteristics}

The three divisions of the Pleistocene (Subunit $A_{1}$, Subunit $A_{2}$, and Unit $B$ ) have seismic facies characteristics that remain rather constant throughout the downdip prism of this sequence. On the updip prism it is difficult 


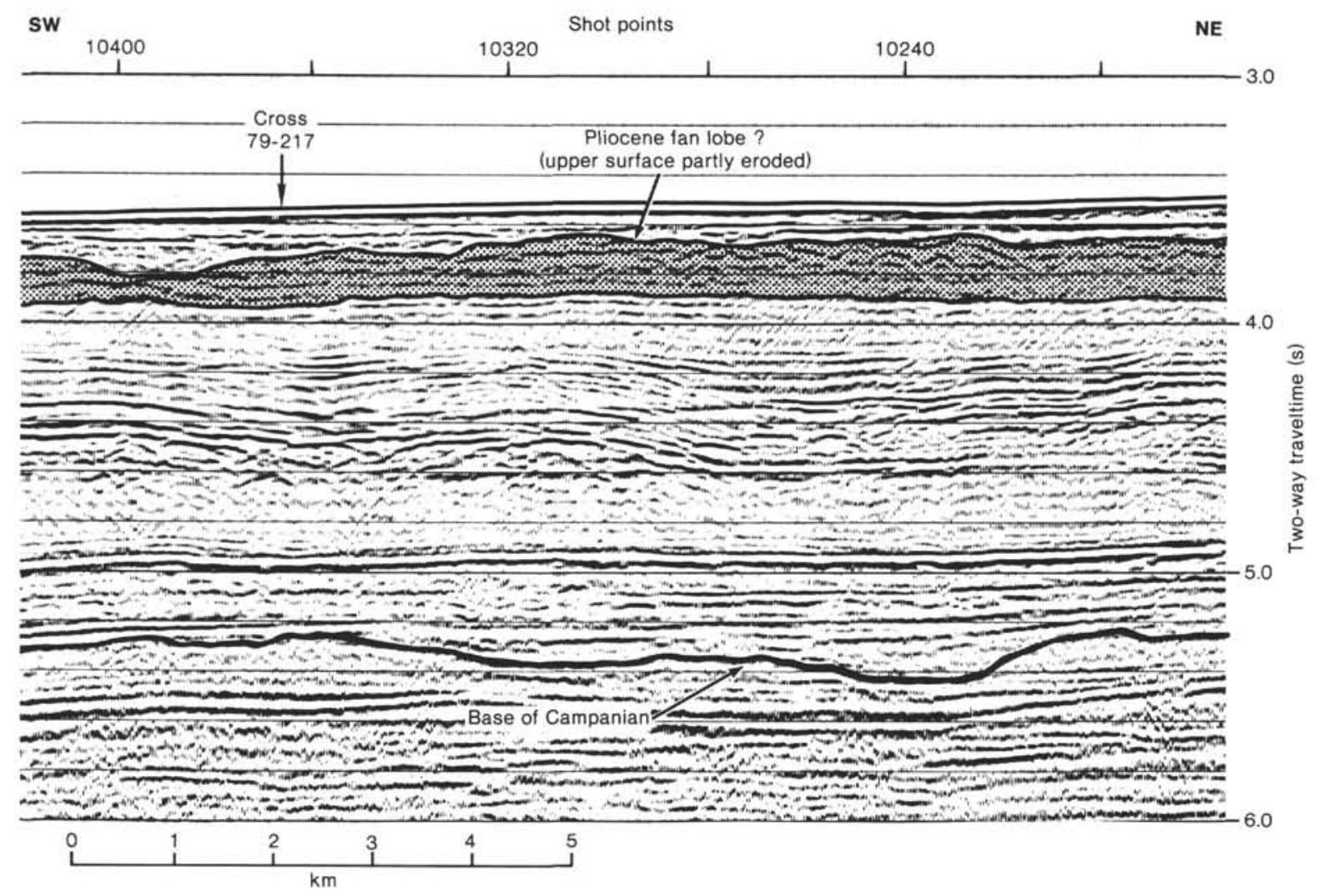

Figure 31. Fan lobe of Pliocene strata (Sequence 2) along multichannel seismic Line 79-216.

to distinguish the subdivisions consistently, but along Line 79-215, three units can be recognized within a thick prograding lens (Figs. 19, 20 [back pocket]).

\section{IMPLICATIONS FOR MARGIN DEVELOPMENT AND INTERREGIONAL CORRELATION}

\section{Age Discrepancies of Upper Rise Sequences}

The broad aspects of outbuilding and erosion of the New Jersey margin have been discussed above and in previous publications by Tucholke and Mountain (1979), Mountain and Tucholke (1985), and Poag (1985a, b). Poag (1985b) focused particularly on alternative interpretations of the age of the upper-rise deposits and the difficulties of accurately tracing regional deep-sea seismic reflectors from the lower rise to the New Jersey margin. His extrapolation of the stratigraphy of Holes 604,605 , and 613 yielded a quite different depositional history for this part of the margin than an extrapolation from boreholes on the lower rise presented by Mountain and Tucholke (1985).

The additional analyses carried out for this study have not resolved the question of how the deep-sea seismic reflectors fit into the lithostratigraphic and biostratigraphic framework of the study area. They have, however, reinforced the interpretation that the lower Eocene and middle Eocene sequences are continuous from the upper slope through the upper rise for the length of most of the single-channel and multichannel lines analyzed. The evidence derived from our analysis also indicates that the principal erosional features of the upper rise in the study area (including seismic horizon $\mathrm{A}^{\mathrm{u}}$, as defined by Mountain and Tucholke [1985]) are the products of downslope erosion, not necessarily related to corrosive or abrasive deep-sea bottom currents that Mountain and Tucholke believe must have formed reflector $\mathrm{A}^{\mathrm{u}}$ on the lower rise. These disparate origins cast doubt on the validity of extending deep-sea reflector terminology (such as $\mathrm{A}^{\mathrm{u}}$ ) into the upper rise-lower slope prism.

The isopach maps prepared for this study provide a new perspective for evaluating some of the undrilled upper rise sequences. In particular, the restricted distribution pattern and depositional fabric of undrilled Sequence 4 (?middle Miocene?) of Poag [1985b]; Appendix Fig. 14) seems odd in relationship to the well-documented, large, middle Miocene delta, whose depocenter developed at the opposite end of the study area. It is difficult to reconcile such distributional disparity, even if one assumes that the several post-middle Miocene periods of regional erosion could have removed that portion of Sequence 4 that may have originally extended farther to the southwest. In fact, the distribution and fabric of undrilled Sequences 5, 6, and 7 (?upper Oligocene?, ?lower Oligocene? and ?upper Eocene? of Poag, 1985b) (Appendix Figs. 13, 12, 11) appear to be more closely related to the updip middle Miocene delta than does Sequence 4. Furthermore, three distinctive subsequences can be recognized within the updip middle Miocene deltaic complex of the shelf (Fig. 22; Poag, this volume), suggesting to us that Sequences 5,6 , and 7 should be considered as local subsequences of a thickened downdip middle-Miocene sequence. Sequence 4, on the other 
hand, seems more likely to be a subsequence of upper Miocene Sequence 3, which thickens to the northeast on the upper rise and on the adjacent shelf as well (Poag, this volume). Lower Miocene, Oligocene, and upper Eocene sequences are not clearly differentiated in the upper-rise wedge (although they might be included in Sequence 7), and must await further drilling for identification.

\section{Derivation of Hummocky and Shingled Reflectors}

The recognition of a thick middle Eocene sequence along Line 25 at a level previously assigned to the middle Oligocene-lower Miocene (Mountain and Tucholke, [1985]) leads one of us (CWP) to suggest alternative interpretations of lithologies and depositional style. The Miocene strata of the rise (and of the shelf and slope, as well) are relatively unconsolidated terrigeneous siliclas- tics, whereas the middle Eocene strata are indurated biosiliceous carbonates. This is the section in which Mountain and Tucholke (1985) described hyperbolic and ("hummocky") "shingled" seismic reflectors, which they attributed to depositional features formed by bottom currents (or, in local exceptions, by downslope processes). An alternative origin (not subscribed to by GSM) for some of the shingled reflections seen on Line 25 is the fractured and irregularly eroded surface of an indurated chalk and limestone section of middle Eocene age (Fig. 32). Robb et al. (1983) and Farre and Ryan (1985) have described in detail the brittle behavior of the indurated middle Eocene carbonates where they crop out on the seafloor at the base of the continental slope. The exposed surface of this sequence is characterized by a complex variety of cliffs, chutes, cracks, joints, megajoints, terraces, grooves, furrows, gullys, scarps, blocks, mounds,
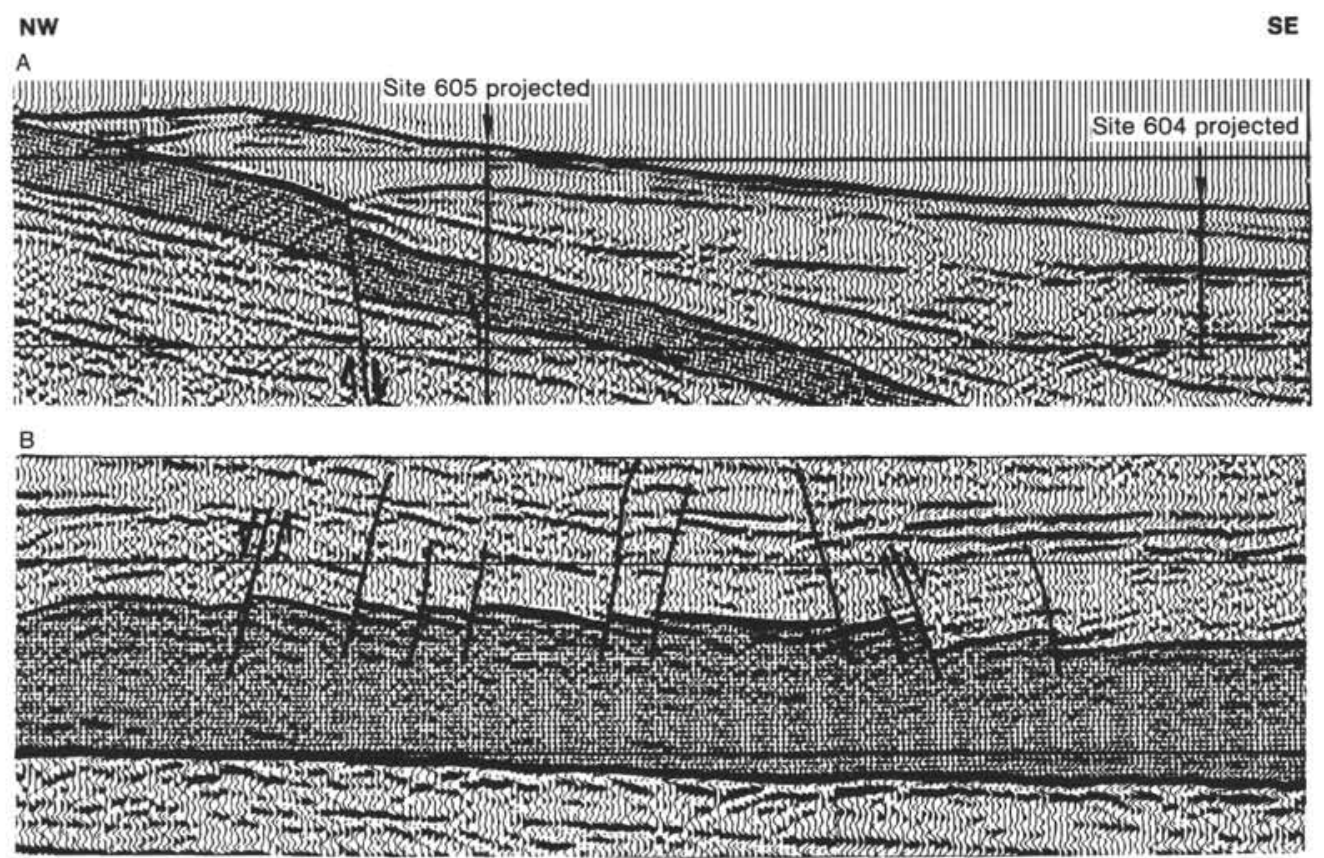

C

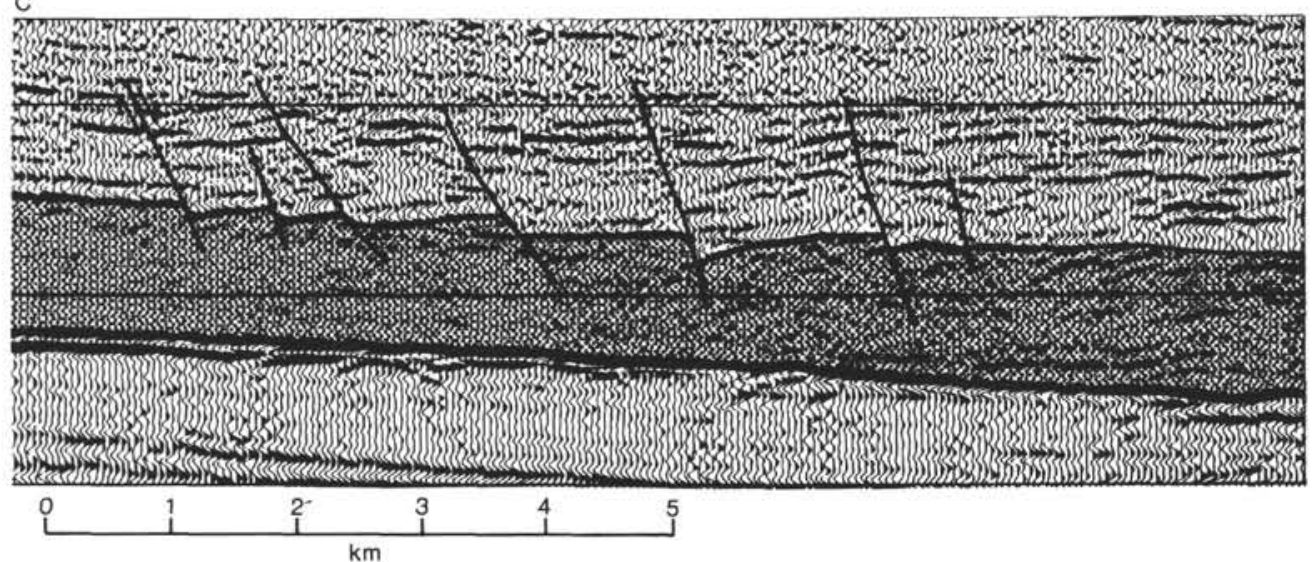

Figure 32. Illustration of irregular (faulted and fractured) surface expression of the indurated middle Eocene carbonates along multichannel seismic Line 25 . A. Large fault near projection of Site 605 . B. Segment near crossing of Line 79-201. C. Downdip segment between shot points 4300 and 4400 . Most faults appear to originate in the middle Eocene section, often extending upward through a considerable thickness of overlying sequences. 
channels, and pits. The single-channel seismic lines described above (Figs. 11, 13) show that faulting is an important process in the middle Eocene section well downdip from the seafloor exposures, and all lines show that the downdip surface is heavily eroded. These features may have been an integral part of the middle Eocene history all along Line 25 (Fig. 32, and extending outside the study area), and could account for many of the hyperbolic and shingled reflections in this area.

\section{Dominant Depositional Fabric}

Mountain and Tucholke (1985) emphasized the dominance of long-slope bottom currents in forming the broad depositional and erosional features of the continental rise during the late Paleogene to Holocene time. On a basin-wide scale, bottom currents appear to have smoothed the seafloor morphology and reduced depositional variability along strike.

Clearly, however, a more complex scenario applies to our study area, where downslope sedimentary processes have dominated throughout the Late Cretaceous and Cenozoic (ca. 75 m.y.), as evidenced particularly by the single-channel seismic lines and the isopach maps. Downslope processes probably dominated other upper rise localities along the western North Atlantic margin, as well (D. O'Leary, oral commun., 1985).

\section{Relationships to the Vail Depositional Model}

Our analyses of seismic sequences and their unconformable boundaries has been patterned after the techniques pioneered by Vail et al. (1977), which have been used extensively in a broad variety of marine geological studies (e.g., Schlee, 1981; Angstadt et al., 1985). The location of the New Jersey DSDP sites along singlechannel and multichannel seismic grids coupled with downhole logging and lithostratigraphic and biostratigraphic studies (e.g., Poag and Low, this volume) have revealed that the principal depositional sequences and unconformities identified at the boreholes can be traced widely in the study area, and are correlative with those of the shelf (Poag and Schlee, 1984; Poag, 1985a; Popenoe, 1985), of the coastal plain (Owens and Gohn, 1985; Ward and Strickland, 1985), and of the margins of several other continents (Aubry, 1985; Barr and Berggren, 1981; Loutit and Kennett, 1981; McGowan, 1979; Poag et al., 1985; Quilty, 1980; Riggs, 1984; Schlee, 1984; Seiglie and Baker, 1984; Seiglie and Moussa, 1984; Steele, 1976; Ziegler, 1982). There can be little doubt of their close relationship to the supercycles that are the hallmark of the depositional model proposed by Vail et al. (1977).

Furthermore, Poag and Schlee (1984), Poag (1985a), Popenoe (1985), and Ward and Strickland (1985), having analyzed paleoenvironmental and paleobathymetric cycles and patterns of laterally shifting erosional swaths, concluded that Cenozoic depositional supercycles of the U.S. Atlantic margin are correlative with shifts in the position of the paleo-Gulf Stream and ancient shorelines. These shifts are correlative with the sea-level supercycles proposed as the forcing mechanism in the Vail model. The correlation of depositional sequences and unconformities of the slope and rise with those of the shoreward regions of the margin is further evidence that the Vail depositional model is applicable to this sediment-rich passive margin.

\section{SUMMARY AND CONCLUSIONS}

Four nearly continuously cored and partly logged DSDP Sites on the New Jersey Slope and upper Rise provide documented stratigraphies for extrapolation along two closely-spaced grids of single-channel and multichannel seismic reflection profiles. The application of seismostratigraphic analysis and the construction of isopach maps for the resulting 12 seismic sequences show the regional distribution and depositional-erosional fabrics of these sequences. The following principal conclusions can be drawn from this study:

1. Twelve seismic (depositional) sequences are recognized on the upper rise. Eight of these were sampled by the boreholes and can be traced directly or indirectly to equivalents on the continental slope. Four have not been sampled. Three of the unsampled four may be subsequences of a thick middle Miocene delta complex that dominates Cenozoic deposits of the shelf and upper slope; the fourth is tentatively assigned to the upper Miocene.

2. Erosion has been widespread and severe between depositional episodes, creating unconformable contacts between each principal sequence and also within most of them.

3. Downslope mass sediment movement has been the principal source of both deposition and erosion on the lower slope and upper continental rise. A less chaotic depositional regime was present on the upper slope and outer shelf, but the erosional record is similar to that of the lower slope and rise.

4. More than 75 m.y. of differential erosion and chaotic deposition have produced such complicated relationships among the sedimentary strata of the study area, that no single seismic line reliably represents the geology. Only by using grids of closely spaced lines can one hope to decipher the perplexing history buried here.

5 . Extrapolation of the upper-rise borehole stratigraphy (Sites 604, 605, 613) in a seaward direction yields a different geologic history for the upper-rise prism than that derived from published extrapolations from drill sites on the lower rise (Sites 105, 106, 388).

6. The stratigraphic positions of depositional sequences and their bounding unconformities provide additional borehole and seismostratigraphic evidence, which, when combined with correlative data from the adjacent shelf and coastal plain, demonstrate that the supercycles of the Vail depositional model can be widely recognized along the margins of the North Atlantic ba$\sin$.

7. The complex and pervasive systems of channels and channel-fill that dominate the study area have confounded efforts to sample all the Cenozoic depositional sequences with only four coreholes. DSDP Legs 93 and 95 succeeded in reaching most of these sequences and answered many of the principal questions posed prior to drilling. However, it is obvious that several critical re- 
maining questions can be resolved only by additional drilling into the unsampled sections.

\section{ACKNOWLEDGMENTS}

We thank P. L. Heller, L. F. Jansa, and E. Uchupi for their thoughtful reviews of the original manuscript.

\section{REFERENCES}

Angstadt, D. M., Austin, J. A., Jr., and Buffler, R. T., 1985. Early Late Cretaceous to Holocene seismic stratigraphy and geologic history of southeastern Gulf of Mexico. Am. Assoc. Pet. Geol. Bull., 69:977-995.

Aubry, M. P., 1985. Northwestern European Paleogene magnetostratigraphy, biostratigraphy, and paleogeography: Calcareous nannofossil evidence. Geology, 13:198-202.

Barr, F. T., and Berggren, W. A., 1981. Lower Tertiary biostratigraphy and tectonics of northeastern Libya. In Solem, M., and Busrewil, M.-T. (Eds.), The Geology of Libya, (Vol. 1): London (Academic Press), 163-192.

Farre, J. A., 1985. The importance of mass wasting processes on the continental slope [Ph.D. thesis]. Columbia University, New York.

Farre, J. A., and Ryan, W. B. F., 1985. 3-D view of erosional scars on U.S. mid-Atlantic continental margin. Am. Assoc. Pet. Geol. Bull., 69:923-932.

Hampson, J. C., Jr., and Robb, J. M., 1984. A geologic map of the continental slope off New Jersey; Lindenkohl Canyon to Toms Canyon. U.S. Geol. Survey Misc. Invest. Ser. I-1608 scale I:50,000, 1 sheet.

Hollister, C. D., Ewing, J., et al., 1972. Init. Repts. DSDP, 11: Washington (U.S. Govt. Printing Office).

Klitgord, K. D., and Grow, J. A., 1980. Jurassic seismic stratigraphy and basement structure of western Atlantic magnetic quiet zone. Am. Assoc. Pet. Geol. Bull., 64:1658-1680.

Loutit, T. S., and Kennett, J. P., 1981. New Zealand and Australian Cenozoic sedimentary cycles and global sea-level changes. $\mathrm{Am}$. Assoc. Pet. Geol. Bull., 65:1586-1601.

McGowran, B., 1979. The Tertiary of Australia: Foraminiferal overview. Marine Micropal., 4:235-264.

Mountain, G. S., and Tucholke, B. E., 1985. Mesozoic and Cenozoic geology of the U.S. Atlantic continental slope and rise. In Poag, C. W. (Ed.), Geologic Evolution of the United States Atlantic Margin: New York (Van Nostrand Reinhold), pp. 293-341.

Owens, J. P., and Gohn, G. S., 1985. Depositional history of the Cretaceous Series in the U.S. Atlantic Coastal Plain: Stratigraphy, paleoenvironments, and tectonic controls of sedimentation. In Poag, C. W. (Ed), Geological Evolution of the United States Atlantic Margin: New York (Van Nostrand Reinhold), pp. 25-86.

Poag, C. W., 1978. Stratigraphy of the Atlantic Continental Shelf and Slope of the United States. Ann. Rev. Earth Planet. Sci., 6: 251-280.

, 1979. Stratigraphy and depositional environments of Baltimore Canyon trough. Am. Assoc. Pet. Geol. Bull., 63:1452-1466.

1980. Foraminiferal biostratigraphy, paleoenvironments, and depositional cycles in the Baltimore Canyon trough. In Scholle, P.A. (Ed.), Geologic Studies of the COST No. B-3 Well, United States Mid-Atlantic Continental Slope Area. U.S. Geol. Survey Circ. 833, pp. 44-65.

1984. Neogene stratigraphy of the submerged U.S. Atlantic margin. Paleogeogr., Palaeoclimatol., Palaeoecol., 47:103-127.

1985a. Depositional history and stratigraphic reference section for central Baltimore Canyon trough. In Poag, C. W. (Ed.), Geologic Evolution of the United States Atlantic Margin: New York (Van Nostrand Reinhold), pp. 217-263.

, 1985b. Cenozoic and Upper Cretaceous sedimentary facies and depositional systems of the New Jersey slope and rise. In Poag, C. W. (Ed.), Geologic Evolution of the United States Atlantic Margin: New York (Van Nostrand Reinhold), pp. 343-365.

Poag, C. W., Reynolds, L. A., Mazzullo, J., and Keigwin, L. D., Jr., 1985. Foraminiferal, lithic, and isotopic changes across four major unconformities at DSDP-IPOD Site 548, Goban Spur. In Graciansky, P. C. de, Poag, C. W., et al., Init. Repts. DSDP, 80, Pt. 1: Washington (U.S. Govt. Printing Office), pp. 539-556.
Poag, C. W., and Schlee, J. S., 1984. Depositional sequences and stratigraphic gaps on submerged United States Atlantic margin. In Schlee, J. S. (Ed.), Interregional Unconformities and Hydrocarbon Accumulation. Am. Assoc. Pet. Geol., Mem. 36:165-182.

Popenoe, P., 1985. Cenozoic depositional and structural history of the North Carolina margin from seismic-stratigraphy analyses. In Poag, C. W. (Ed.), Geologic Evolution of the United States Atlantic Margin: New York (Van Nostrand Reinhold), pp. 125-187.

Prior, D. B., Coleman, J. M., and Doyle, E. H., 1984. Antiquity of the continental slope along the middle Atlantic margin of the United States. Science, 223:926-928.

Quilty, P. G., 1980. Sedimentation cycles in the Cretaceous and Cenozoic of Western Australia. Tectonophysics, 63:349-366.

Riggs, S. R., 1984. Paleoceanographic model of Neogene phosphorite deposition, U.S. Atlantic Continental Margin. Science, 223:123131.

Robb, J. M., and Hampson, J. C., Jr., 1983. Mid-Atlantic upper continental rise: Preliminary study of surficial geology and processes. In McGregor, B. A. (Ed.), Environmental Geologic Studies on the United States Mid and North Atlantic Outer Continental Shelf Area, 1980-1982: Vol. II, Mid-Atlantic Region. Final report submitted to the U.S. Bureau of Land Management, p. 10-1-10-27.

Robb, J. M., Hampson, J. C., Jr., Kirby, J. R., and Twichell, D. C., 1981. Geology and potential hazards of the continental slope between Lindenkohl and South Toms Canyons, offshore mid-Atlantic United States. U.S. Geol. Survey, Open File Rept. 81-600, 33 pp.

Robb, J. M., Kirby, J. R., Hampson, J. C., Jr., Gibson, P. R., and Hecker, B., 1983. Furrowed outcrops of Eocene chalk on the lower continental slope offshore New Jersey. Geology, 11:182-186.

Schlee, J. S., 1981. Seismic stratigraphy of Baltimore Canyon trough. Am. Assoc. Pet. Geol. Bull., 65:26-53.

1984. Interregional unconformities and hydrocarbon accumulation. Am. Assoc. Petrol. Geol. Mem., 36:1-184.

Schlee, J. S., Dillon, W. P., and Grow, J. A., 1979. Structure of the continental slope off the eastern United States. In Doyle, L. J., and Pilkey, O. H. (Eds.), Geology of Continental Slopes. Soc. Econ. Paleont. Mineral. Spec. Publ., 27:95-117.

Schlee, J. S., and Fritsch, J., 1982. Seismic stratigraphy of the Georges Bank basin, complex, offshore New England. In Watkins, J. S., and Drake, C. L. (Eds.), Studies in Continental Margin Geology. Am. Assoc. Pet. Geol. Mem., 34:223-251.

Seiglie, G. A., and Baker, M. B., 1984. Relative sea-level changes during the Middle and Late Cretaceous from Zaire to Cameroon (Central West Africa). In Schlee, J. S. (Ed.), Interregional Unconformities and Hydrocarbon Accumulation. Am. Assoc. Pet. Geol. Mem., $36: 81-88$.

Seiglie, G. A., and Moussa, M. T., 1984. Late Oligocene-Pliocene transgressive regressive cycles of sedimentation in northwestern Puerto Rico. In Schlee, J. S. (Ed.), Interregional Unconformities and Hydrocarbon Accumulation. Am. Assoc. Pet. Geol. Mem., 36:89-95.

Steele, R. J., 1976. Some concepts of seismic stratigraphy with application to the Gippsland basin. Australian Pet. Explor. Assoc. Jour., $16: 67-71$.

Tucholke, B. E., and Mountain, G. S., 1979. Seismic stratigraphy, lithostratigraphy, and paleosedimentation patterns in the North American basin. In Talwani, M., Hay, W. W., and Ryan, W. B. F. (Eds.), Deep Drilling Results in the Atlantic Ocean: Continental Margins and Paleoenvironments: Washington D.C. (American Geophysical Union), Maurice Ewing Series 3:58-86.

Vail, P. R., Mitchum, R. M., Jr., and Thompson, S., III, 1977. Seismic stratigraphy and global changes of sea level. Part Four: Global cycles of relative changes of sea level. In Payton, C. E. (Ed.), Seismic Stratigraphy-Applications to Hydrocarbon Exploration. Am. Assoc. Pet. Geol., Mem., 26:83-98.

van Hinte, J. E., Wise, S. W., et al., in press. Init. Repts. DSDP, 93: Washington (U.S. Govt. Printing Office).

Ward, L. W., and Strickland, G. L., 1985. Outline of Tertiary stratigraphy and depositional history of the U.S. Atlantic Coastal Plain. In Poag, C. W. (Ed.), Geologic Evolution of the United States Atlantic Margin: New York (Van Nostrand Reinhold), pp. 87-123.

Ziegler, P. A., 1982. Geological Atlas of Western and Central Europe: The Hague (Shell Internat. Pet. Maatsch, B.V.), 130 pp. 


\section{APPENDIX}

Stratigraphy Across the Upper Rise: Additional Seismic Lines and Isopach Maps

A
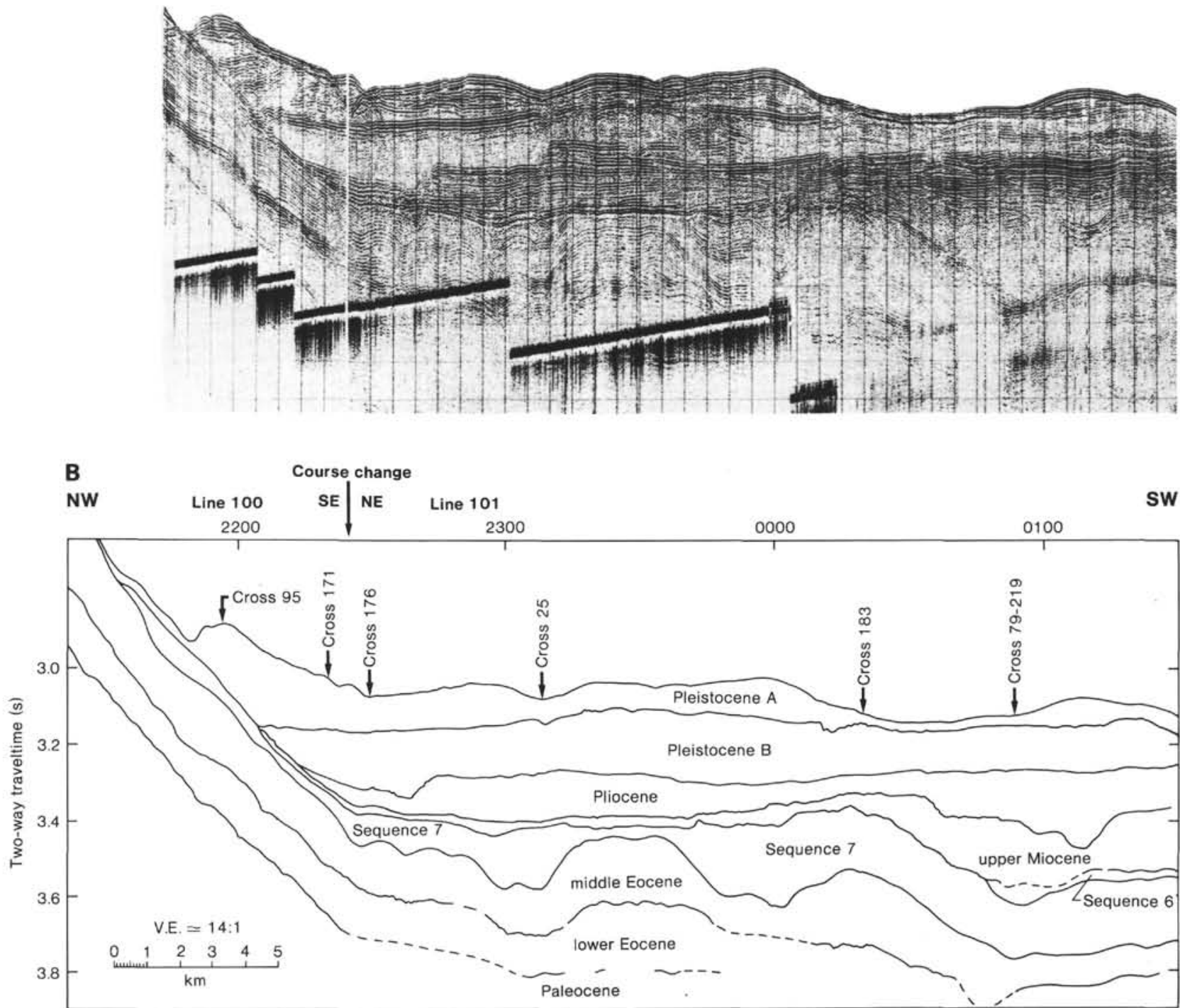

Figure 1. A. Uninterpreted segment of single-channel seismic Lines 100 and 101 . B. Interpretation of single-channel seismic strike Line 101 and part of adjoining strike Line 100. Note onlapping of post-middle Eocene sequences and channeling of all sequences. 

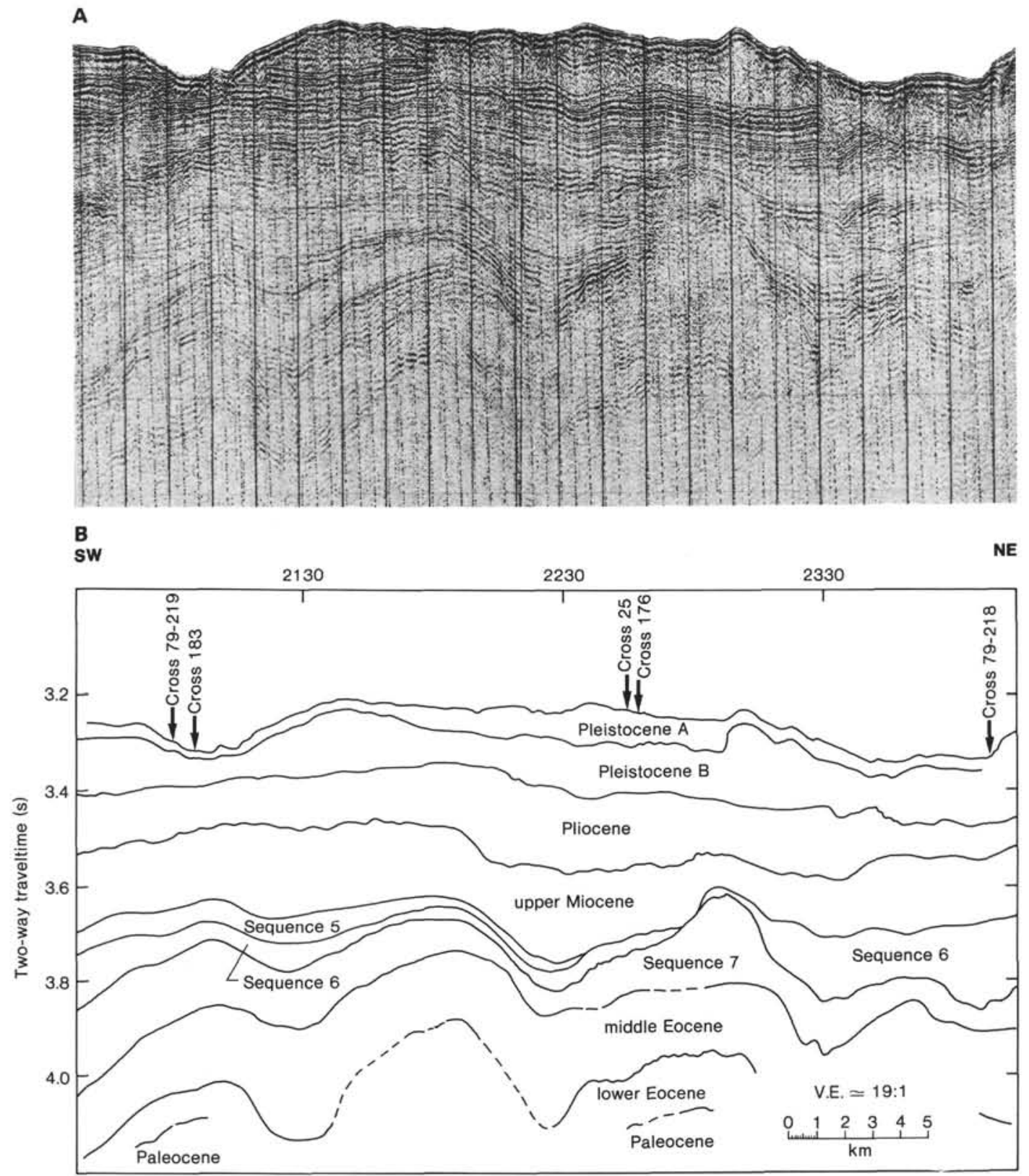

Figure 2. A. Uninterpreted segment of single-channel seismic Line 173. B. Interpretation of single-channel strike Line 173. Note deep channels and variable thickness of sequences. Sequence 5 is absent in NE half of figure. 


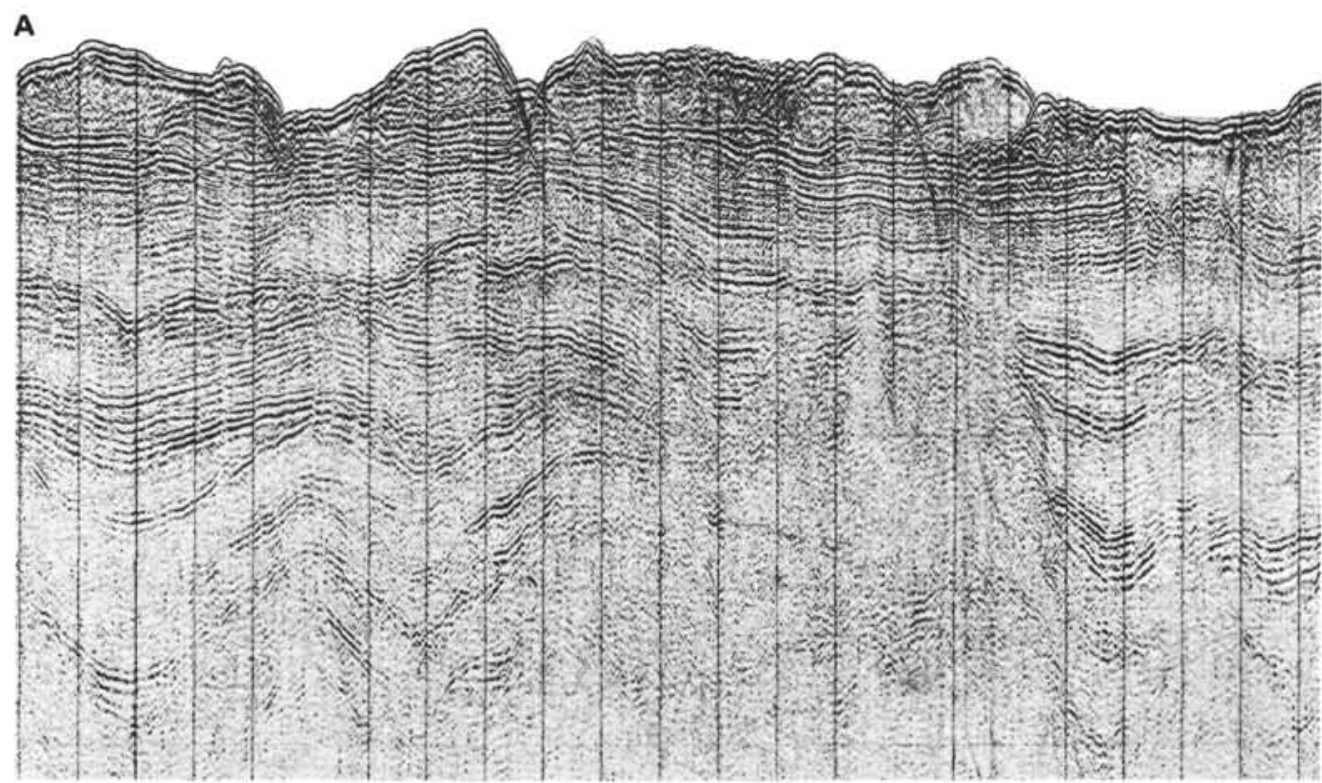

\section{B}

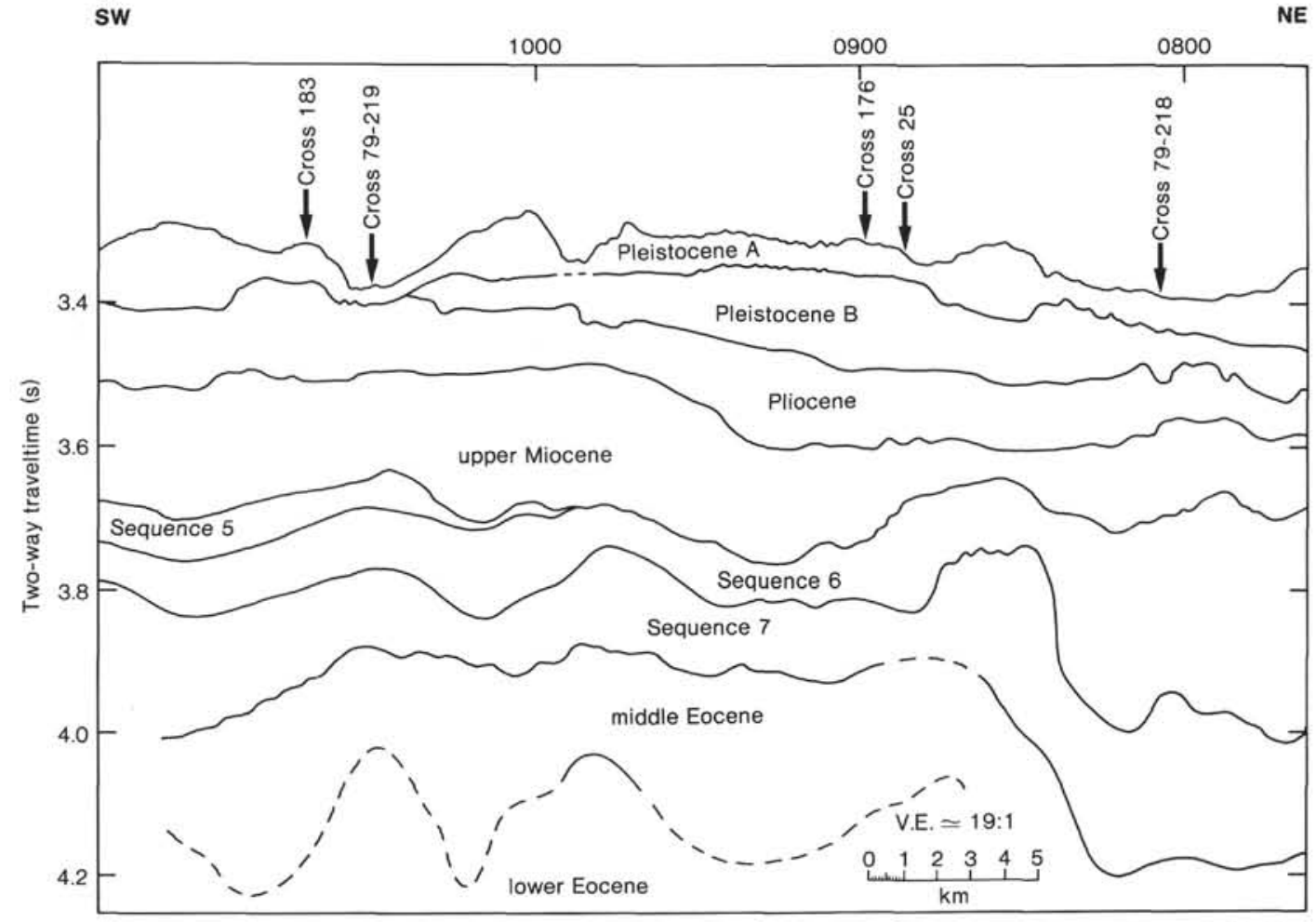

Figure 3. A. Uninterpreted segment of single-channel seismic Line 172. B. Interpretation of single-channel seismic Line 172 . Note channeling of all sequence boundaries, especially the deep channels on the surface of Sequence 7 and the middle Eocene sequence. Sequence 5 is restricted to the SW side of figure; Pleistocene Unit B is absent to the SW. 
A

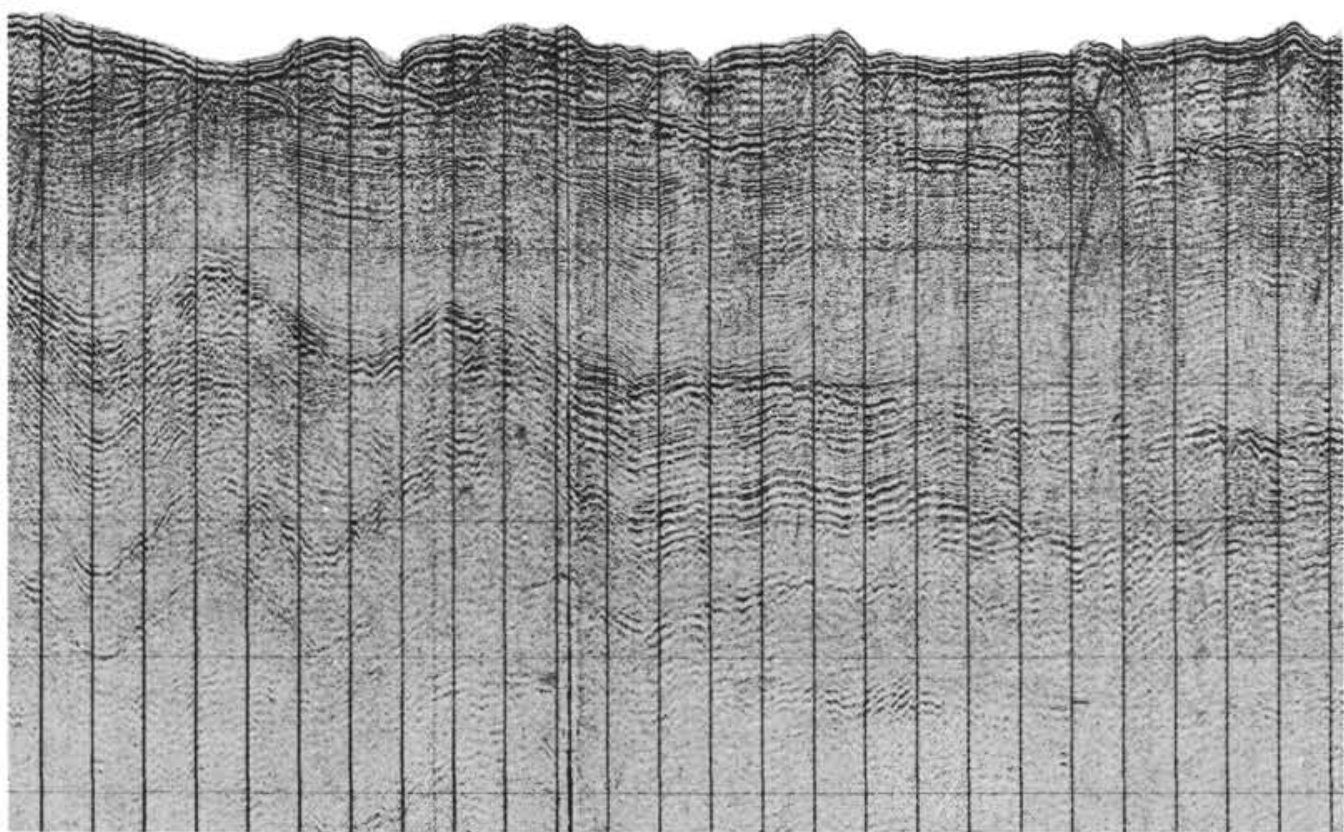

B

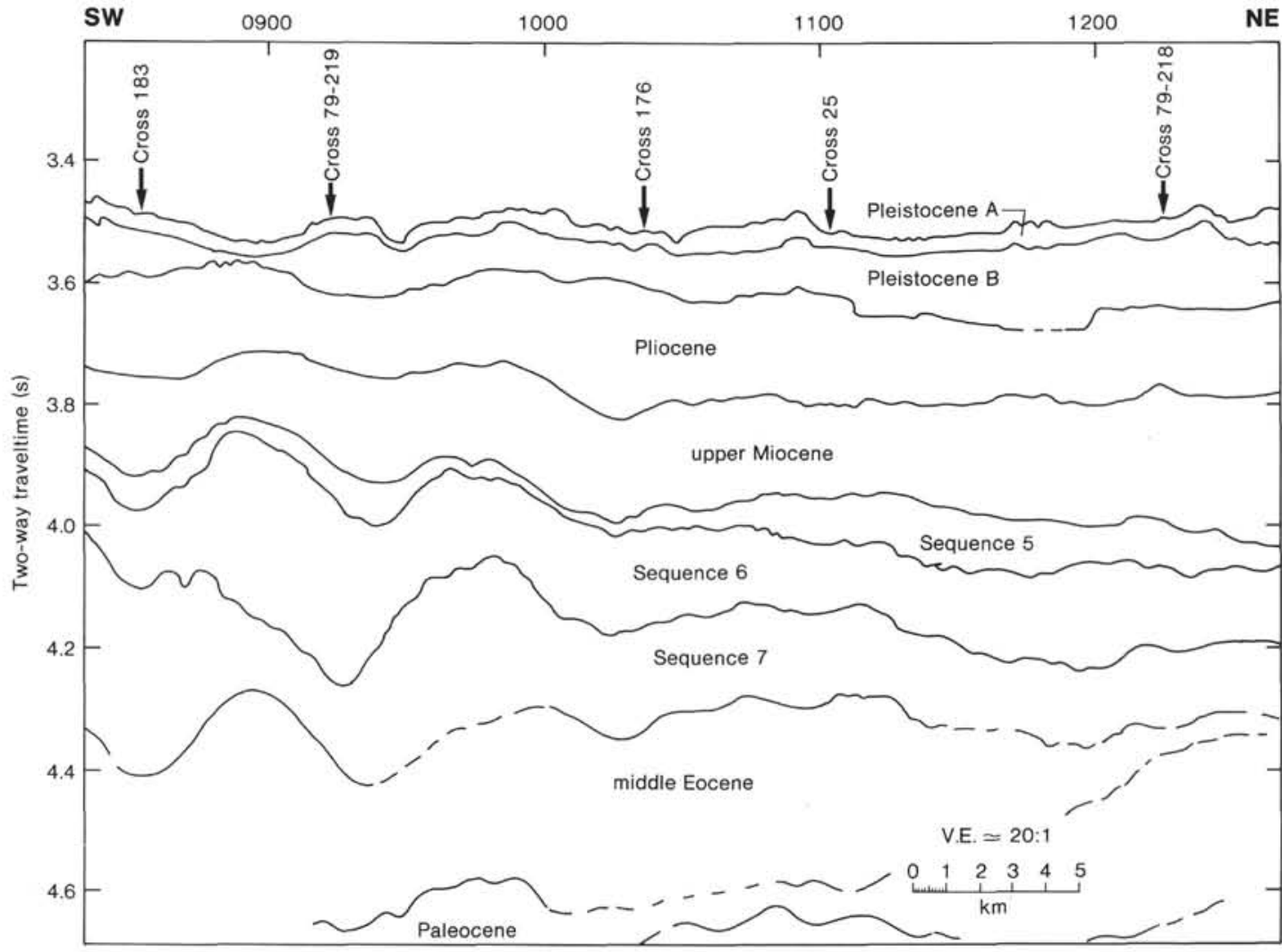

Figure 4. A. Uninterpreted segment of single-channel seismic Line 178. B. Interpretation of single-channel strike Line 178. Note channeling of all sequence boundaries, especially the large channel on the lower Eocene surface. 


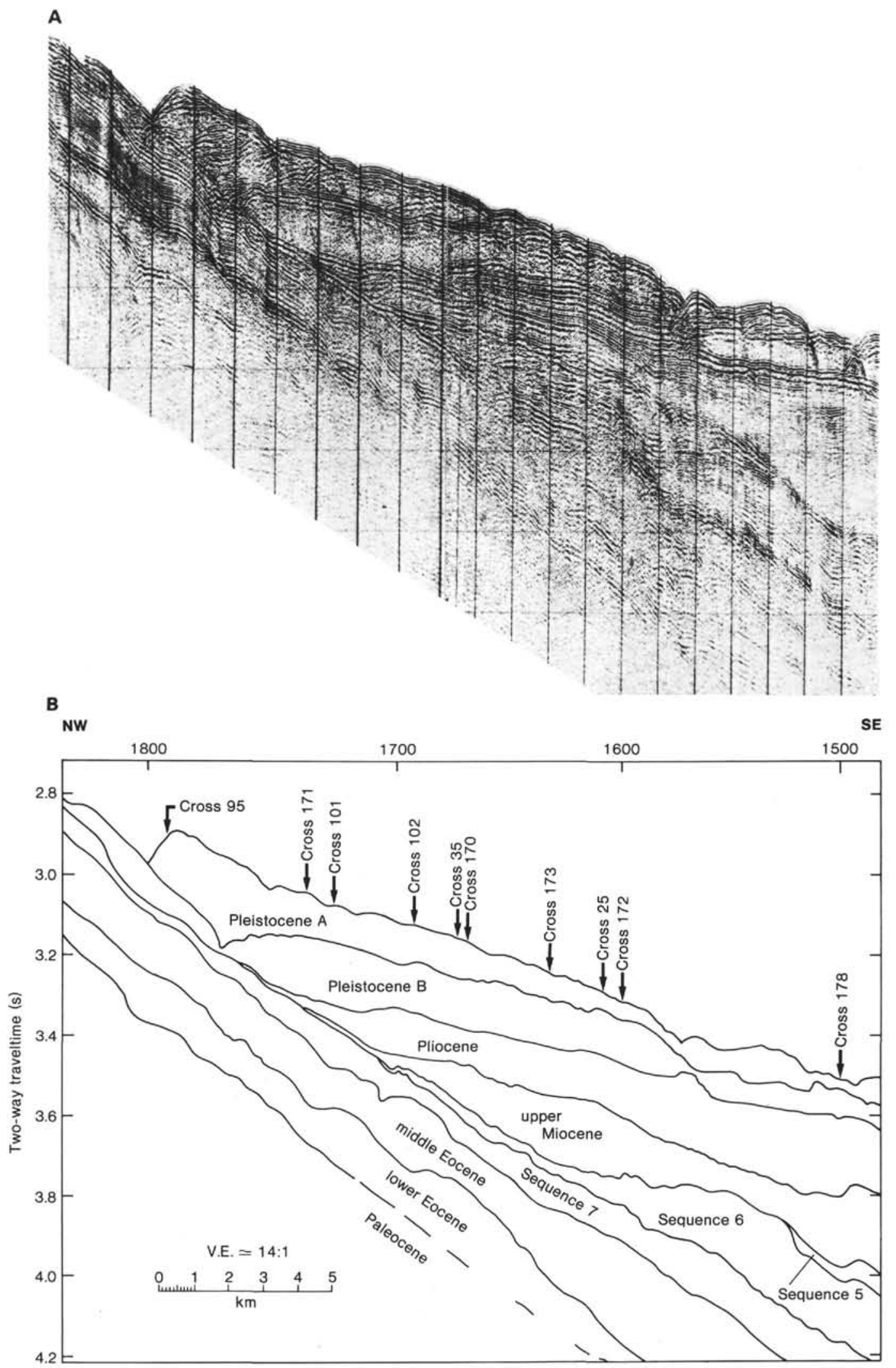

Figure 5. A. Uninterpreted segment of single-channel seismic Line 176. B. Interpretation of single-channel dip Line 176. Note onlapping post-Sequence 7 strata and channeling of most sequence boundaries. Pleistocene Unit A thickens significantly at the foot of the continental slope. 


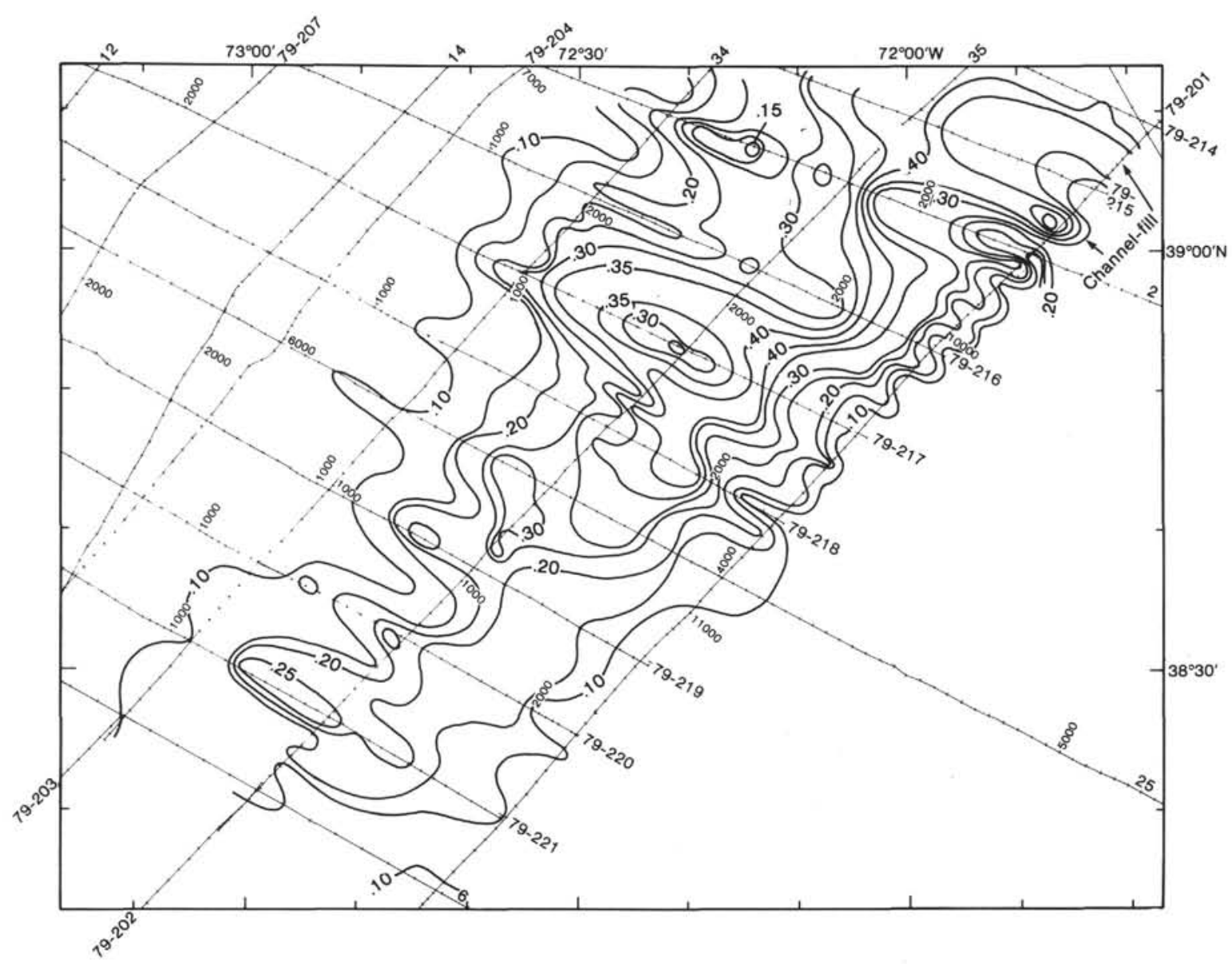

Figure 6. Campanian isopach map of Sequence 12 in the study area. Note dominant downslope "ribbed" fabric caused by cut and fill of extensive channel systems. Sequence thickens to northeast. Contour interval is $0.05 \mathrm{~s}$ two-way traveltime. See text for further discussion of features and depositional history. 


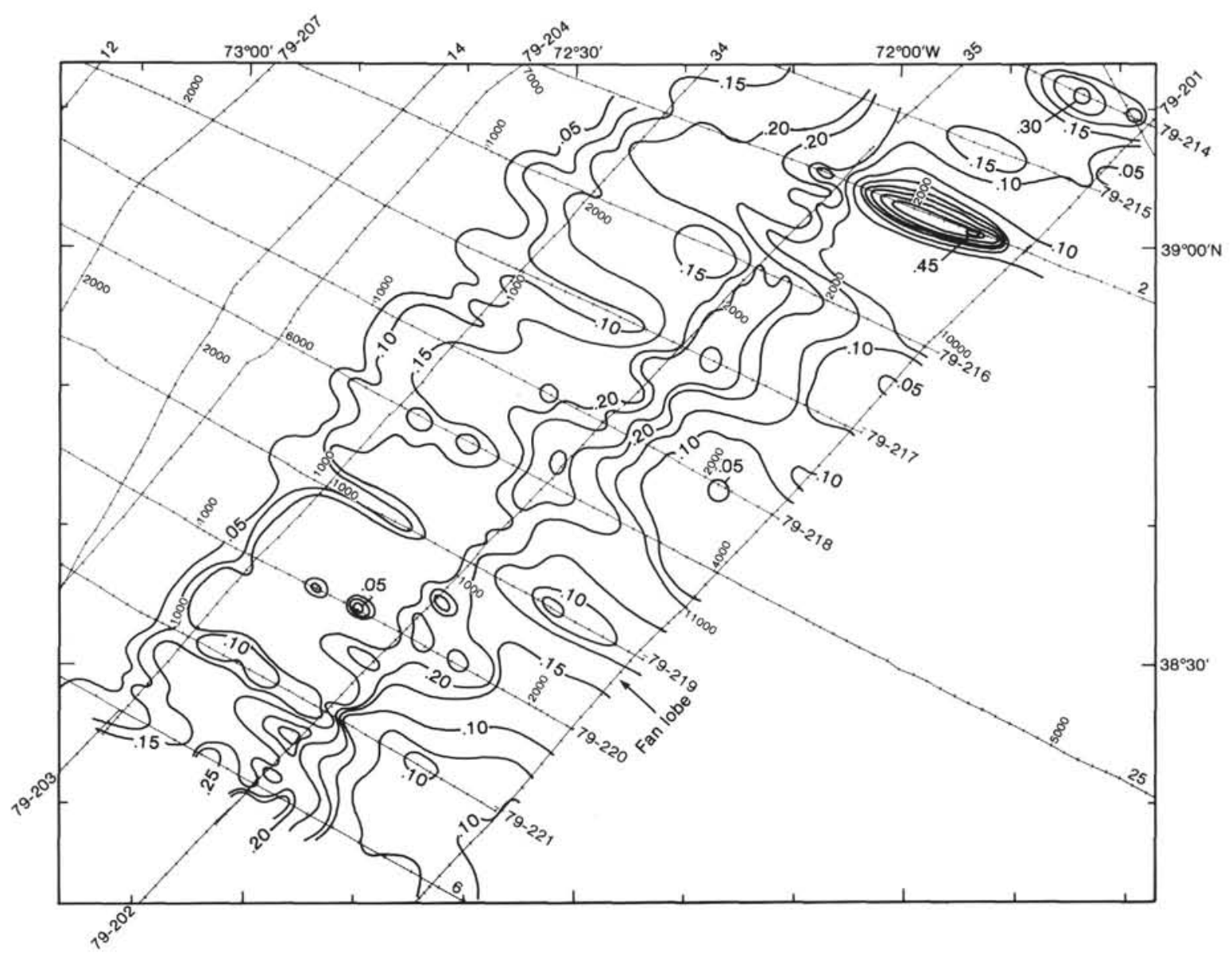

Figure 7. Maestrichtian isopach map of Sequence 11 in the study area. Note dominant downslope "ribbed" fabric caused by cut and fill of extensive channel systems. Contour interval is $0.05 \mathrm{~s}$ two-way traveltime. See text for further discussion of features and depositional history. 


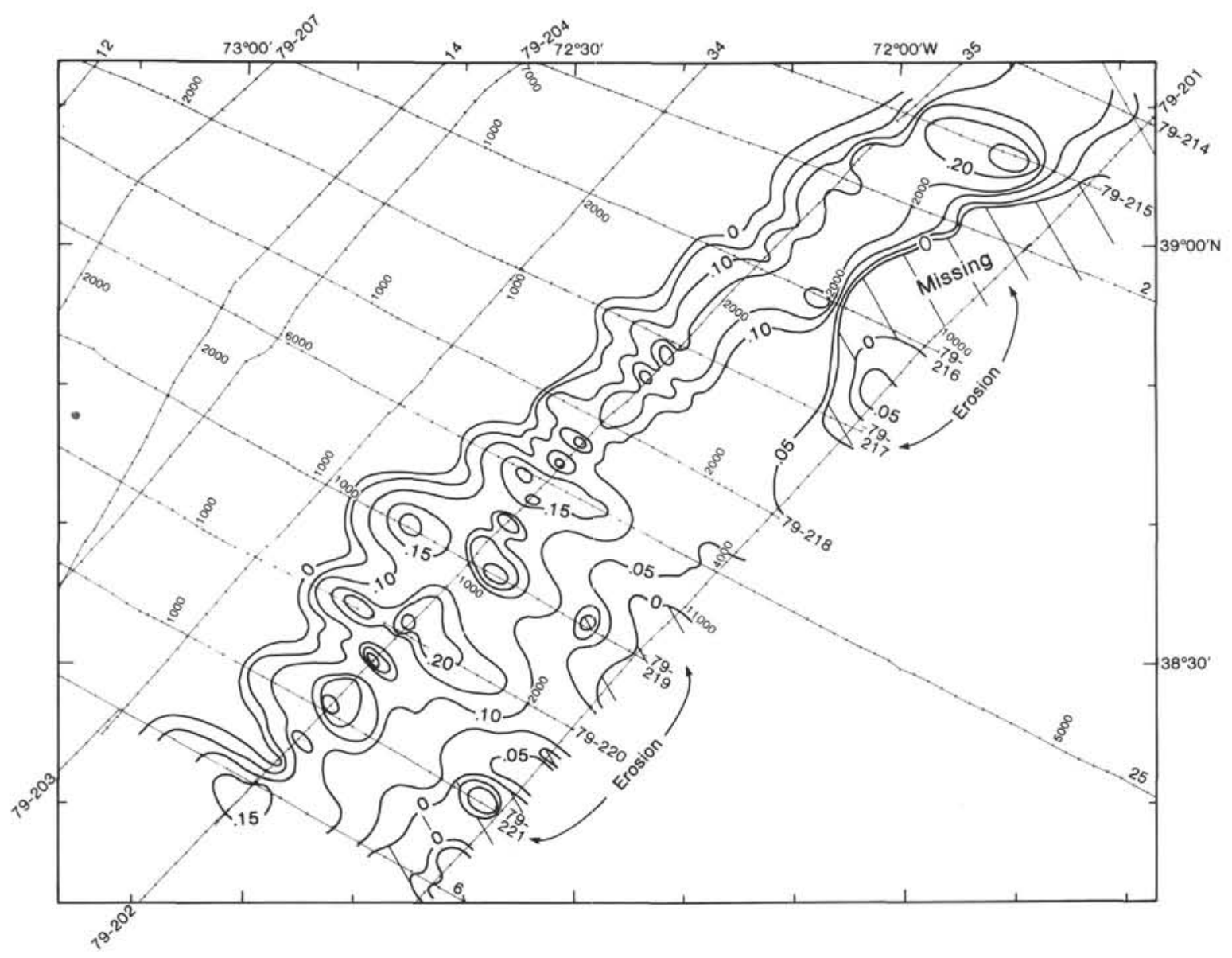

Figure 8. Paleocene isopach map of Sequence 10 in the study area. Note dominant downslope "ribbed" fabric caused by cut and fill of extensive channel systems. Contour interval is $0.05 \mathrm{~s}$ two-way traveltime. See text for further discussion of features and depositional history. 


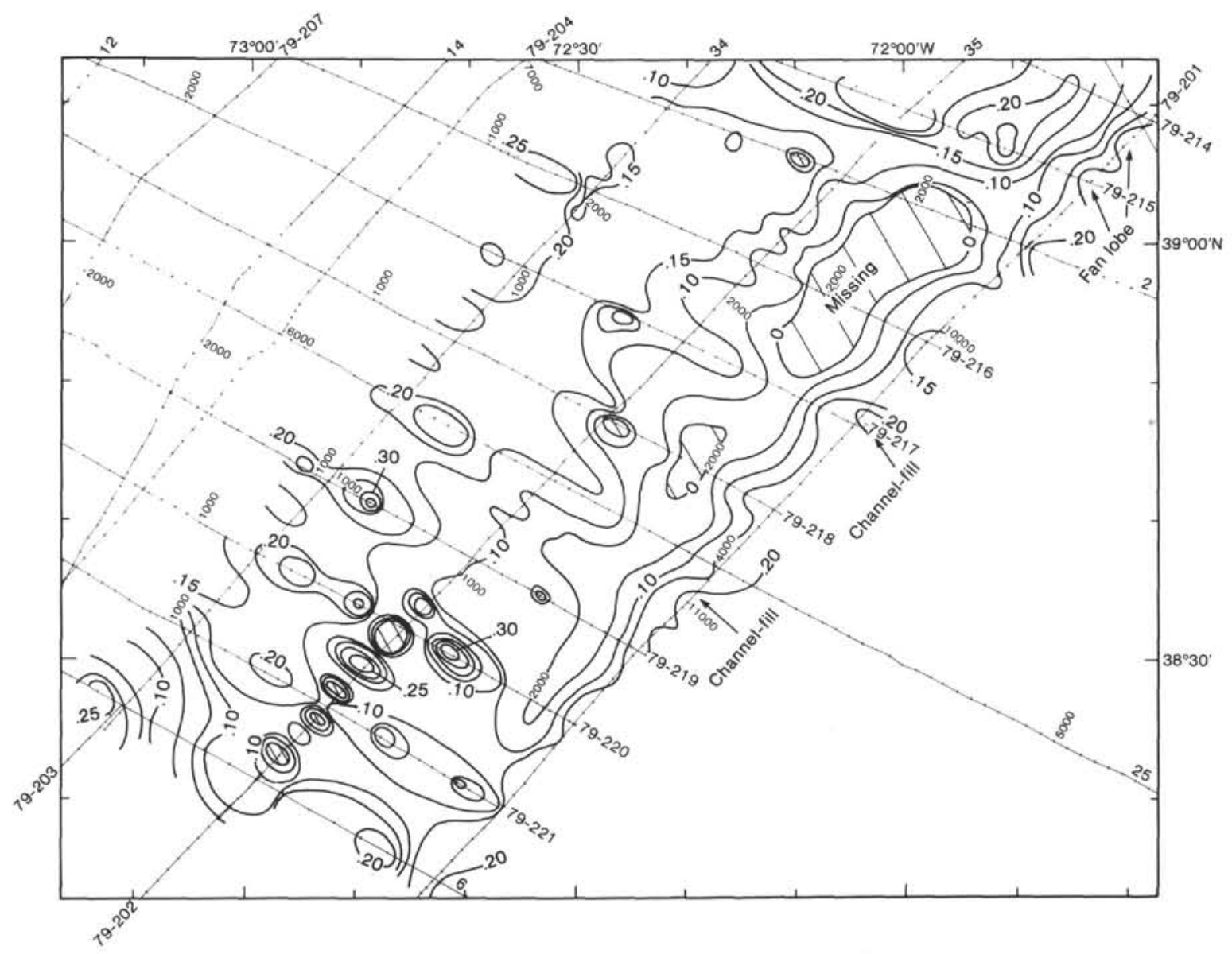

Figure 9. Lower Eocene isopach map of Sequence 9 in the study area. Note dominant downslope "ribbed" fabric caused by cut and fill of extensive channel systems. Longslope erosive swath suggests active bottom currents. Contour interval is $0.05 \mathrm{~s} \mathrm{two-}$ way traveltime. See text for further discussion of features and depositional history. 


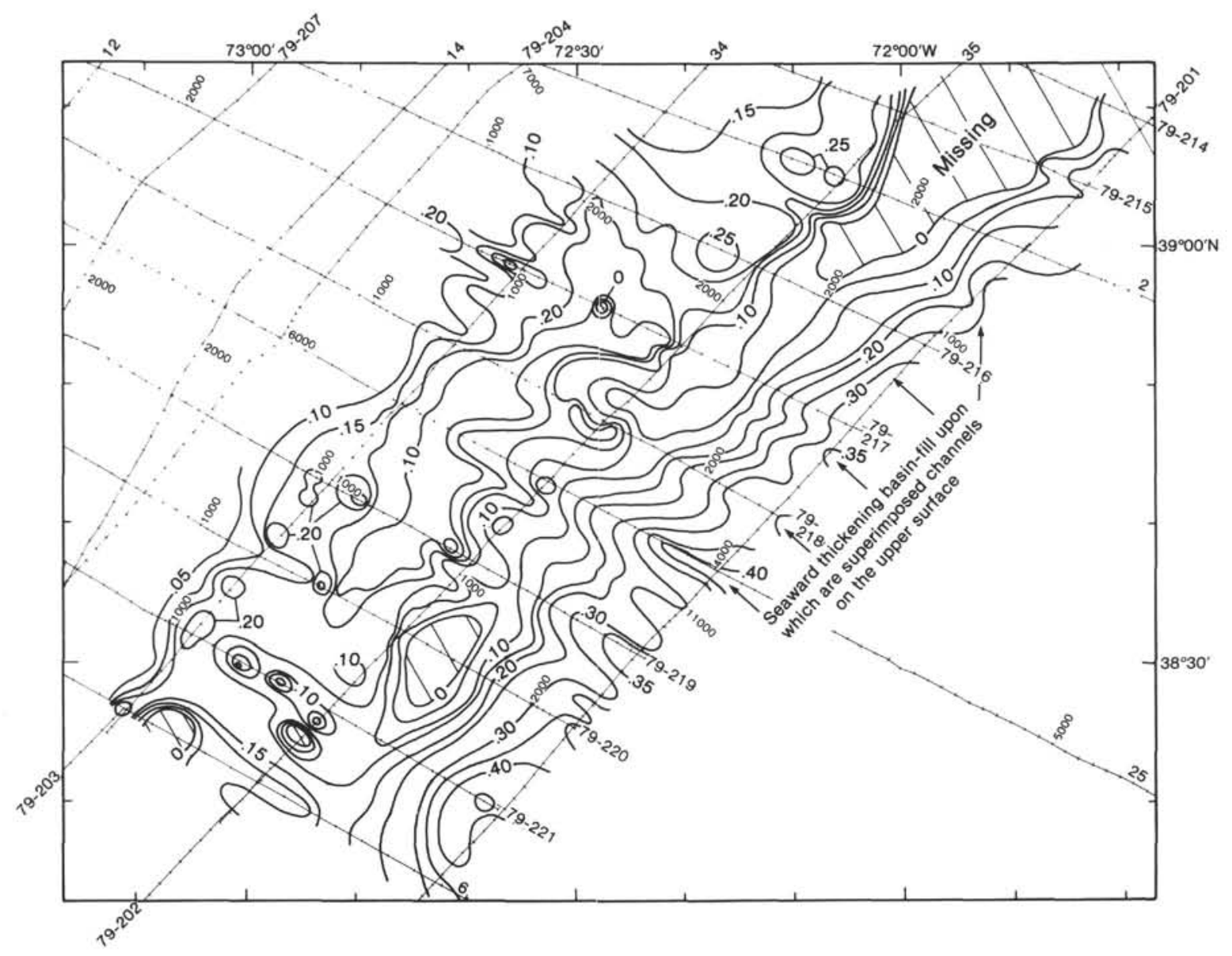

Figure 10. Middle Eocene isopach map of Sequence 8 in the study area. Note dominant downslope "ribbed" fabric caused by cut and fill of extensive channel systems. Longslope erosive swath suggests active bottom currents. Contour interval $0.05 \mathrm{~s}$ twoway traveltime. See text for further discussion of features and depositional history. 


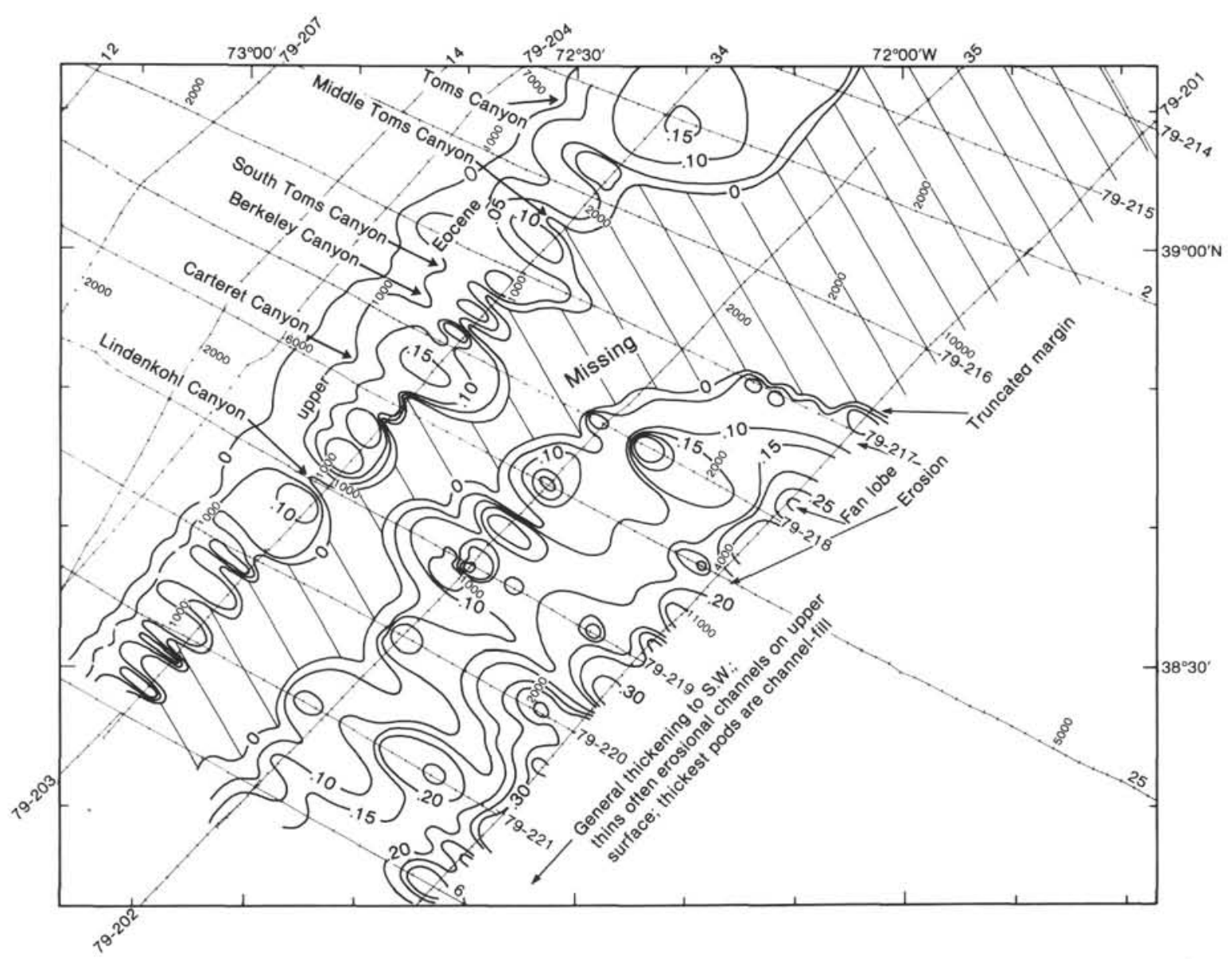

Figure 11. Isopach map of Sequence 7 in the study area. Note dominant downslope "ribbed" fabric caused by cut and fill of extensive channel systems. Sequence restricted to southwest part of upper rise. Contour interval $0.05 \mathrm{~s}$ two-way traveltime. See text for further discussion of features and depositional history. 


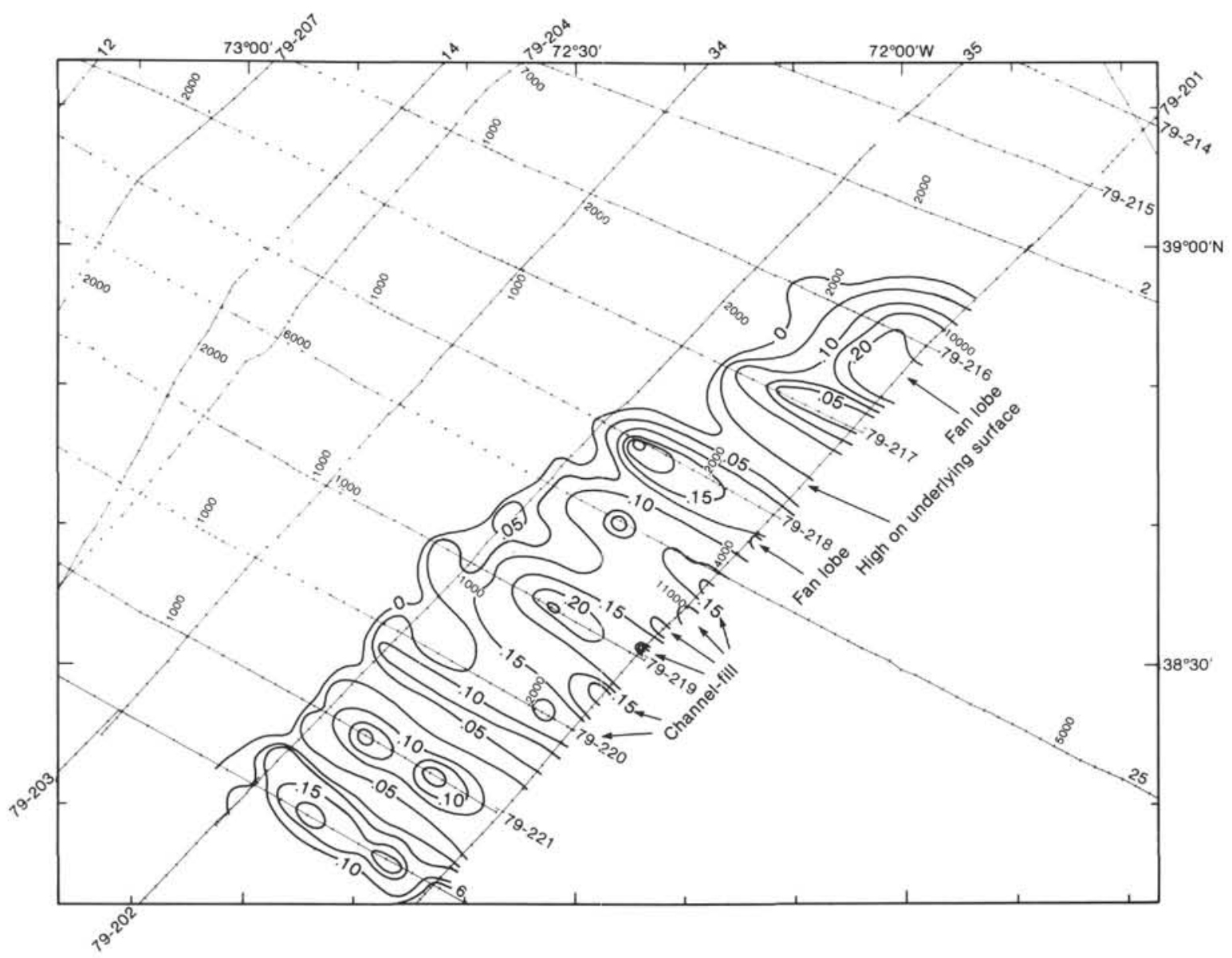

Figure 12. Isopach map of Sequence 6 in the study area. Not dominant downslope "ribbed" fabric caused by cut and fill of extensive channel systems. Sequence restricted to southwest part of upper rise. Contour interval $0.05 \mathrm{~s}$ two-way traveltime. See text for further discussion of features and depositional history. 


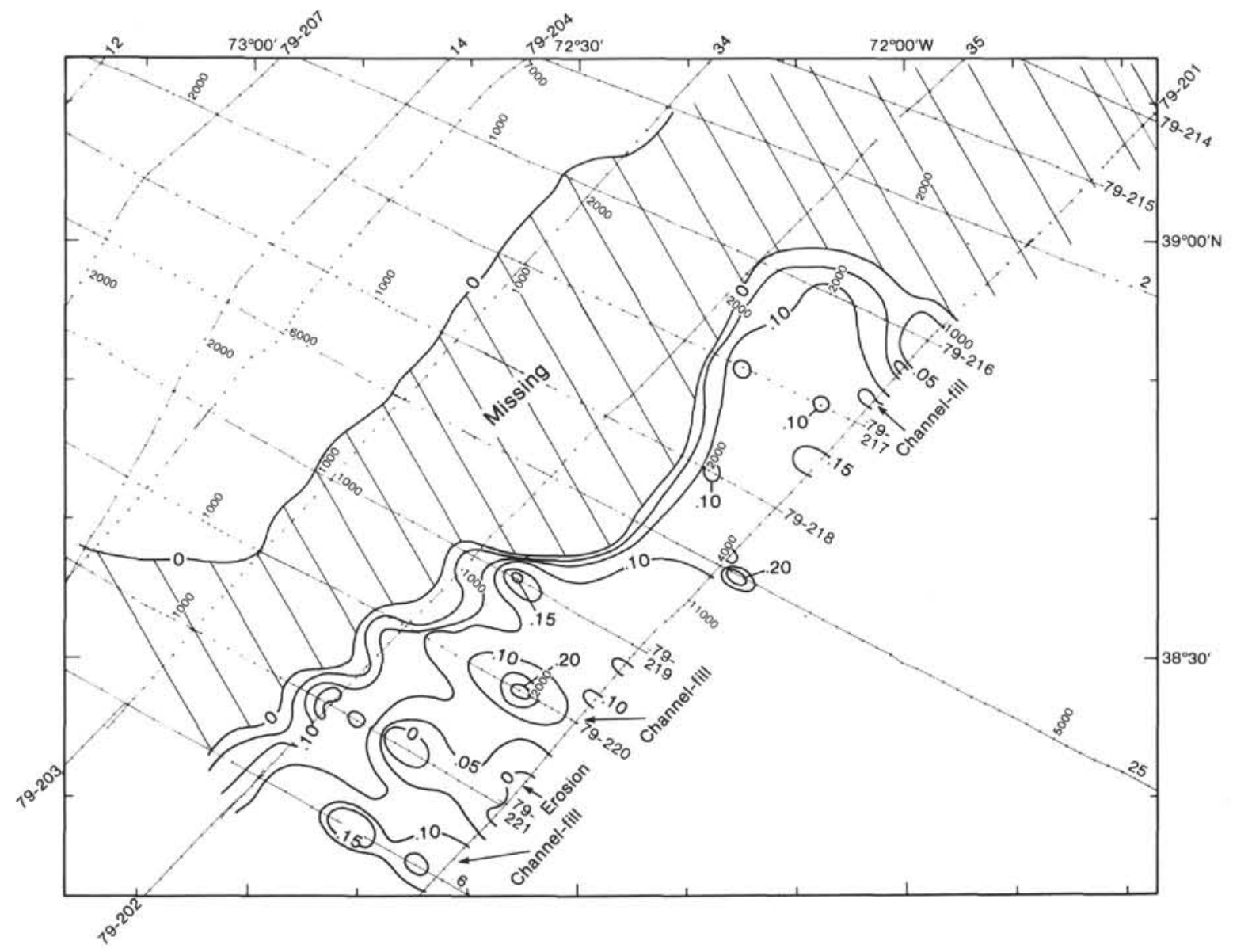

Figure 13. Isopach map of the Sequence 5 in the study area. Note dominant downslope "ribbed" fabric caused by cut and fill of extensive channel systems. Sequence restricted to southwest part of upper rise. Contour interval $0.05 \mathrm{~s}$ two-way traveltime. See text for further discussion of features and depositional history. 


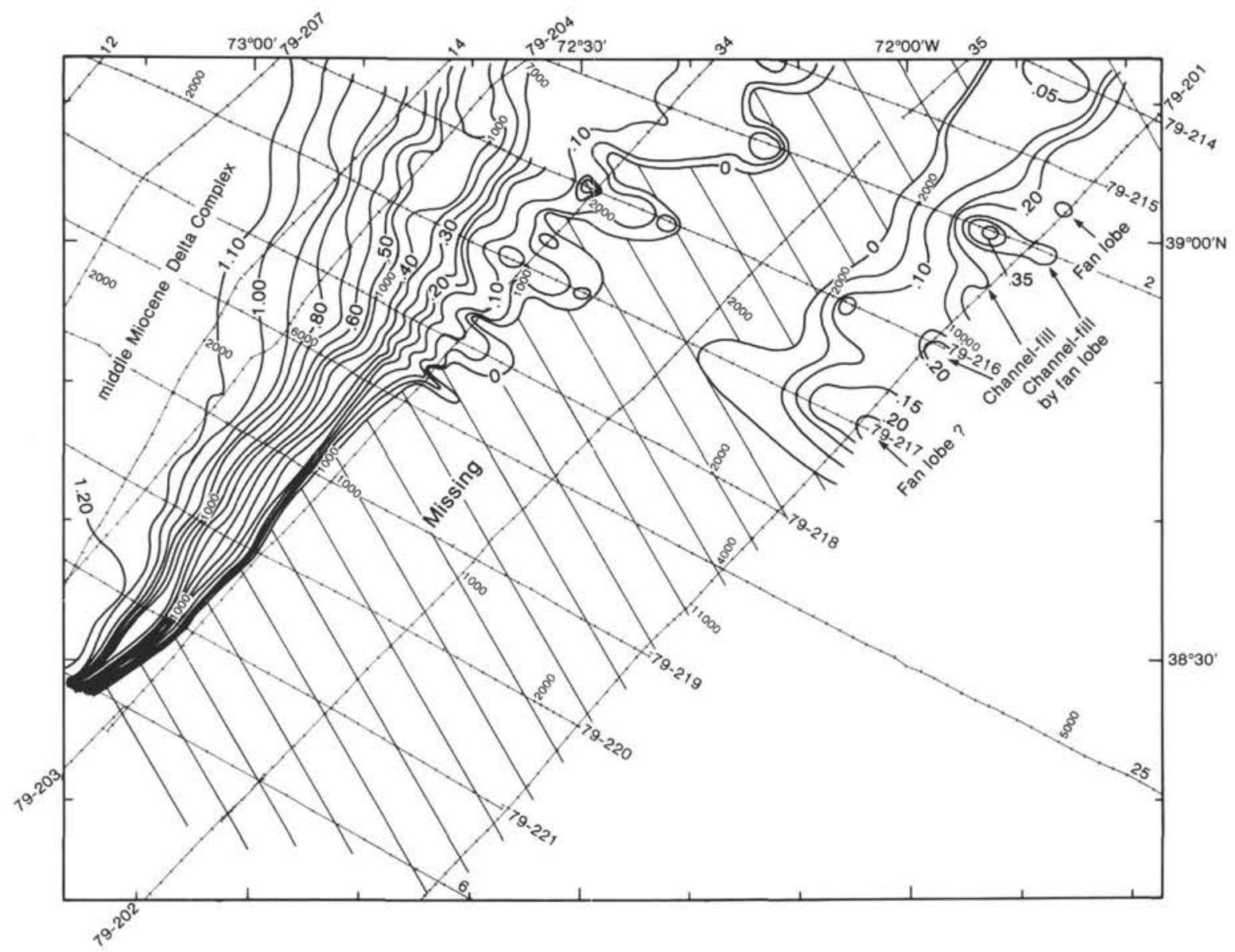

Figure 14. Isopach map of Sequence 4 in the study area. Note dominant downslope "ribbed" fabric caused by cut and fill of extensive channel systems. Sequence restricted to northeast part of upper rise. Note position of middle Miocene delta complex. Contour interval $0.05 \mathrm{~s}$ two-way traveltime. See text for further discussion of features and depositional history. 


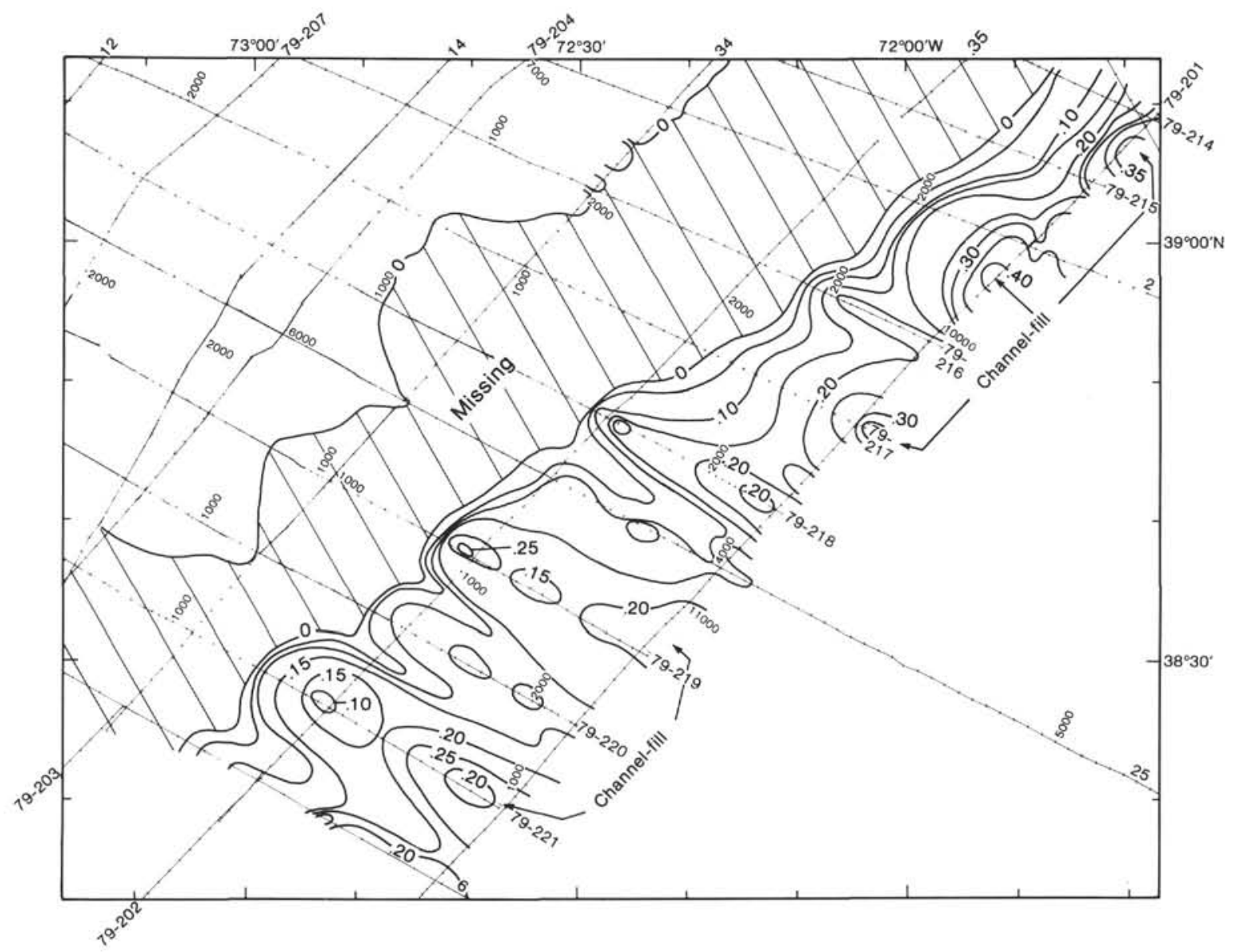

Figure 15. Upper Miocene isopach map of Sequence 3 in the study area. Note dominant downslope "ribbed" fabric caused by cut and fill of extensive channel systems. Sequence thickens to northeast. Contour interval $0.05 \mathrm{~s}$ two-way traveltime. See text for further discussion of features and depositional history. 


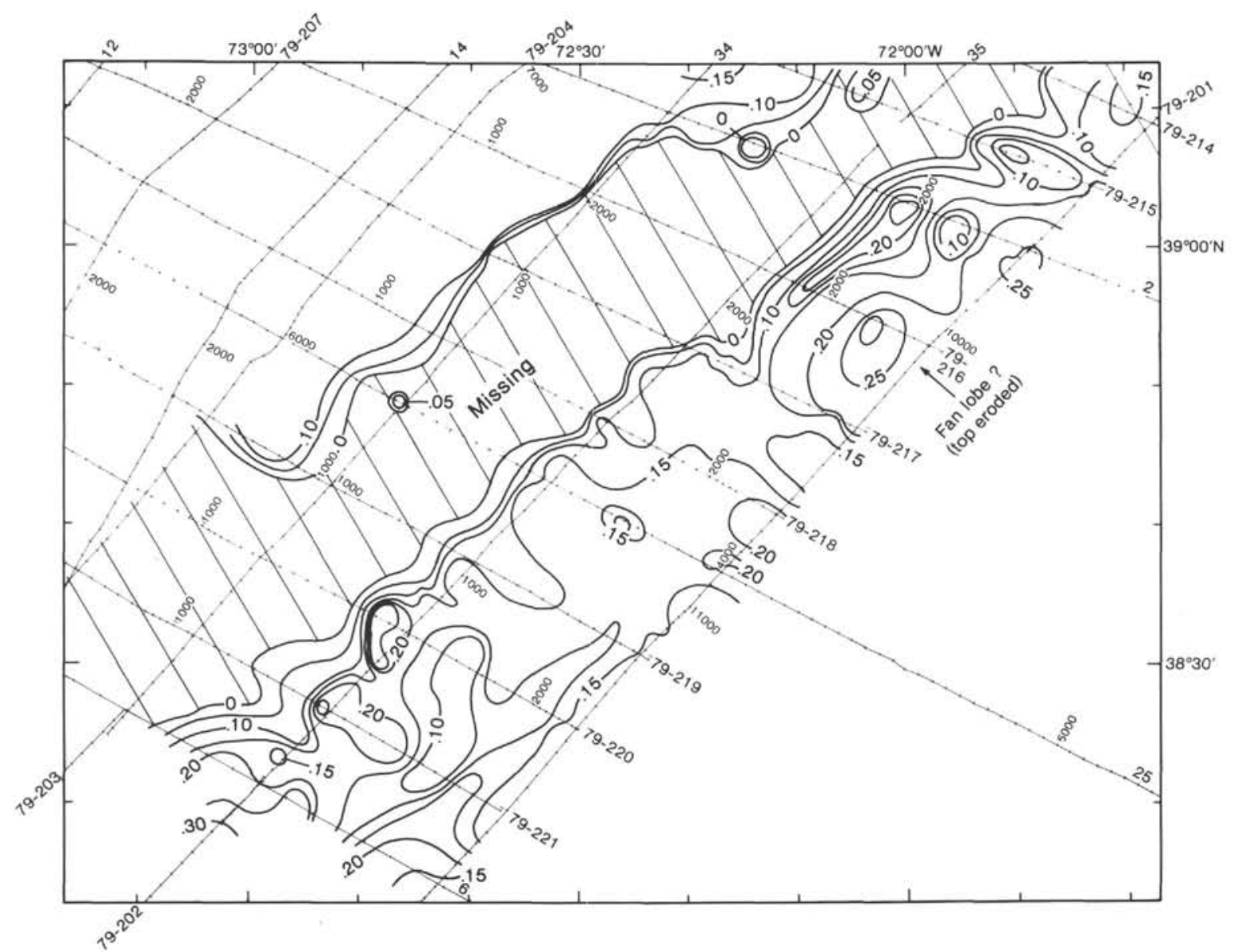

Figure 16. Pliocene isopach map of Sequence 2 in the study area. Note dominant downslope "ribbed" fabric caused by cut and fill of extensive channel systems. Contour interval $0.05 \mathrm{~s}$ two-way traveltime. See text for further discussion of features and depositional history. 


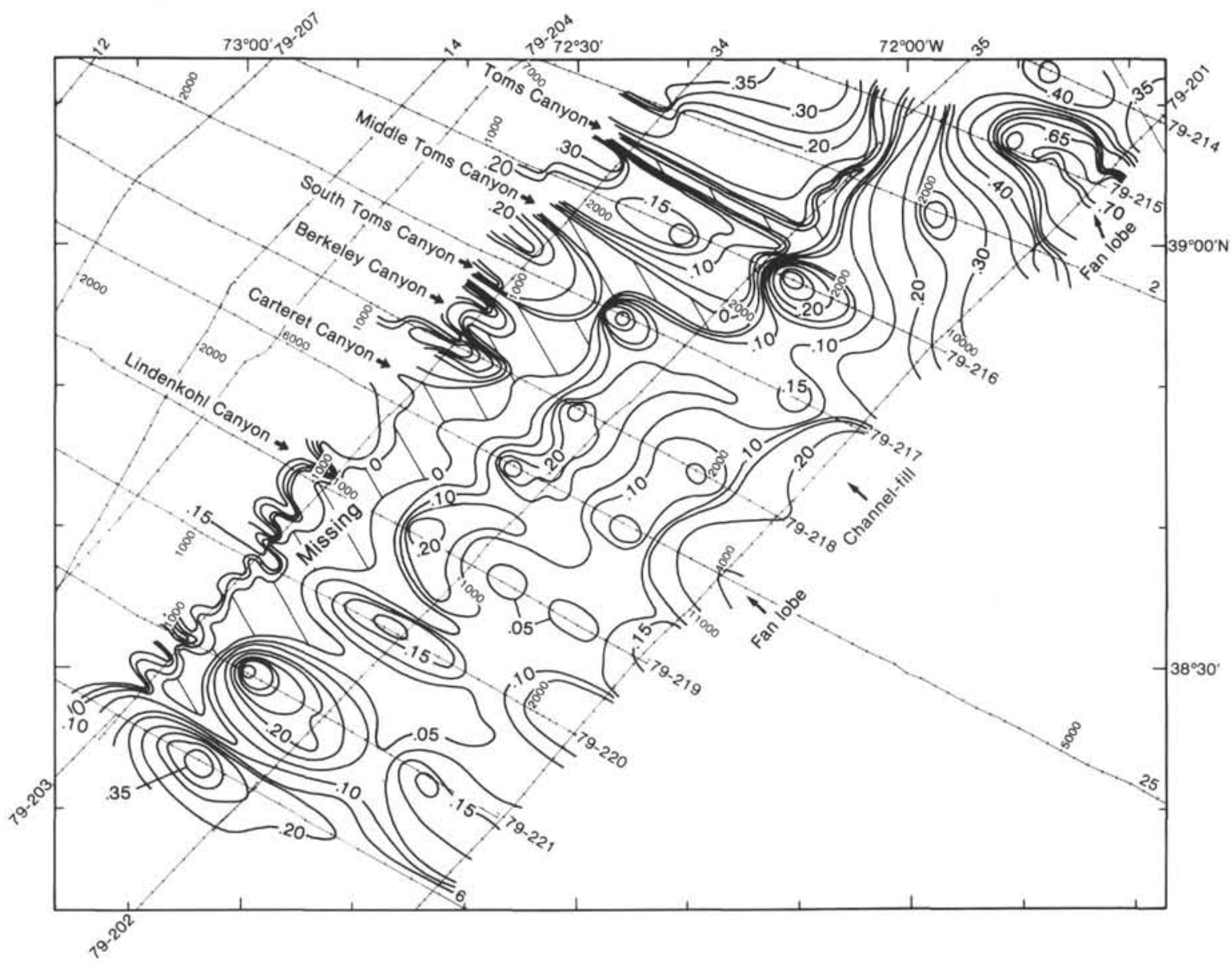

Figure 17. Pleistocene isopach map of Sequence 1 in the study area. Note dominant downslope "ribbed" fabric caused by cut and fill of extensive submarine canyon and channel systems. Contour interval $0.05 \mathrm{~s}$ two-way traveltime. See text for further discussion of features and depositional history. 